\title{
Eletrólitos sólidos poliméricos a base de amidos de mandioca: nativo, acetilado e oxidado - acetilado.
}

\section{ELLEN RAPHAEL}

Dissertação apresentada ao Instituto de Química de São Carlos, da Universidade de São Paulo, para obtenção do título de Mestre em Físico-Química.

Orientadora: Profa. Dra. Agnieszka Joanna Pawlicka Maule 
Dedico esta dissertação à minha família: minha mãe Roseli Rossi Raphael, meu pai José Romeu Raphael e meus irmãos William Raphael e Érica Raphael que sempre me apoiaram incondicionalmente e me ajudaram no que foi preciso. 


\section{AGRADECIMENTOS}

Meu primeiro e especial agradecimento faço a Deus que me deu a vida, saúde e força para vencer mais esta etapa, que jamais me abandonou e me propiciou dentre tantos acontecimentos a realização deste trabalho.

Durante o desenvolvimento deste trabalho, devido à necessidade de utilização de várias técnicas experimentais, tive a oportunidade de contar com a colaboração e incentivo de muitas pessoas, que sempre se mostraram dispostos a contribuir, de forma decisiva, na realização desta pesquisa. Agradeço muito a todos.

Agradeço a Profa. Dra. Agnieszka Pawlicka, pela orientação durante este trabalho. Com sua valiosa orientação nesses dois anos de mestrado, com sua confiança e incentivo, tive a oportunidade de começar a amadurecer como pesquisadora.

À Conselho Nacional de Pesquisa do Estado de São Paulo - CNPQ - pelo apoio financeiro que viabilizou esta dissertação.

\section{Os meus sinceros agradecimentos às seguintes pessoas:}

Prof. Dr. Marcelo Aparecido Chinellato expresso meu sincero reconhecimento e gratidão pela grande disponibilidade em me ajudar no projeto de estágio na área de polímeros e engenharia de materiais, o que com certeza me incentivou ao início deste projeto e por toda a atenção e disponibilidade no auxílio do desenvolvimento do projeto.

Prof. Dr. Douglas Cardoso Dragunski cuja amizade, auxílio no desenvolvimetno do projeto, sugestões e discussões, sempre disponíveis, me guiaram ao longo desta jornada. Meu sincero reconhecimento e gratidão.

Ao Mestre José Donato Ambrósio, Gerente de polímeros do CCDM - Centro de Caracterização e Desenvolvimento de Materiais, pelo apoio, amizade e a disponibilização de utilização de equipamentos e desenvolvimento de técnicas de pesquisa no CCDM.

\section{Às minhas grandes amigas e amigos de estudo e de vida:}

Aos colegas do grupo: Aline, Diogo, César, Marins, aos Rodrigos e Juliana pela amizade, trabalho em conjunto e por sempre me incentivarem e me auxiliarem nos momentos difíceis que enfrentei na pesquisa e em minha vida. Agradeço muito, também, pela confiança em mim e pelos momentos agradáveis que passamos juntos.

Aos amigos e companheiros do laboratório do CCDM - Rosa, Rubens, Marcelo, Juliene, Heitor, Ricardo, Alessandra, Ângela, Janaína, Fábio, Rosângela e Tatiana pelo companheirismo, intensa troca de conhecimento e por me receberem como parte do grupo e me tratarem com carinho e amizade.

Aos grandes amigos Flávia, Mildred, Cláudia, Márcia, Daniele, Carlos, Thaís, Marcela, Tânia, Juliene, Juliana, Ana, Aline e Alexandre.

Ao meu namorado Marcos por todo apoio e carinho dedicados e pela paciência despendida comigo durante os momentos de dificuldade.

Aos assistentes de pesquisa Mauro, Silvana, Edson, Carlos, Marcia e Vânia pela realização das análises instrumentais e pelas explicações. 
Em especial, ao técnico Luiz Carlos (Luizão) pela amizade, apoio e grande disponibilidade em me ajudar.

Às bibliotecárias do IQSC pela atenção, correções e ajuda nas buscas e normalizações bibliográficas.

A todos os professores, alunos e funcionários do Instituto de Química que me ajudaram na concretização deste trabalho.

\section{Minha querida família:}

Com todo amor e carinho aos meus pais que sempre me conduziram na busca de novos caminhos para que eu alcançasse sempre maior desenvolvimento emocional e intelectual.

Aos meus queridos irmãos William e Érica pelo companheirismo, amor e por me ajudarem nos momentos bons e nos difíceis de minha vida.

Aos meus avós Hermindo e Albina pela amizade, amor, incentivo, apoio e principalmente pelo enorme carinho.

A todos aqueles que de algum modo, com seu auxílio e colaboração tornaram possível a realização desta tese. Ficam aqui meus votos de agradecimento a todas as pessoas que fizeram de mim pesquisadora e, assim, proporcionaram minha evolução intelectual e amadurecimento emocional.

\section{Muito obrigada!}




\section{SUMÁRIO}

LISTA DE FIGURAS ....................................................................... viii

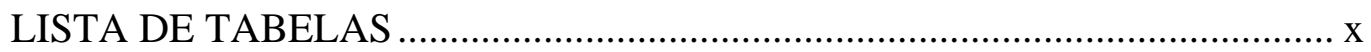

LISTA DE ABREVIATURAS E SÍMBOLOS ............................................. $\mathrm{xi}$

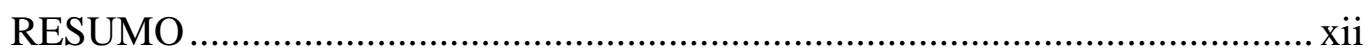

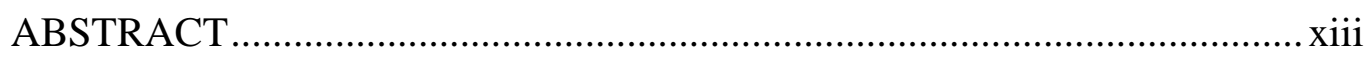

CAPÍTULO I - INTRODUÇÃO ........................................................................ 1

1.1 - Eletrólitos sólidos poliméricos .............................................................. 1

1.2 - Eletrólitos sólidos a base de polímeros naturais ........................................ 8

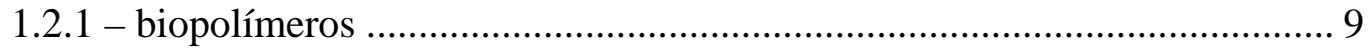

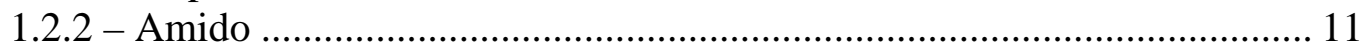

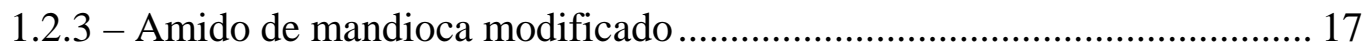

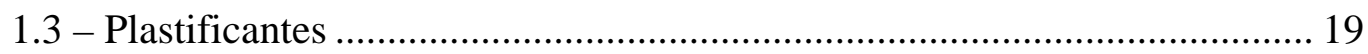

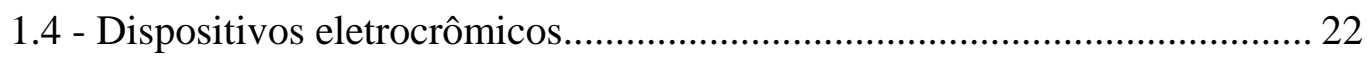

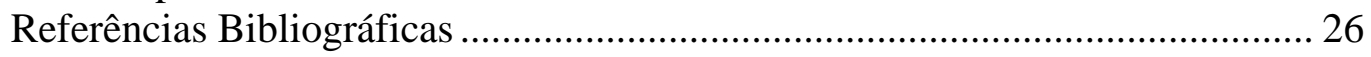

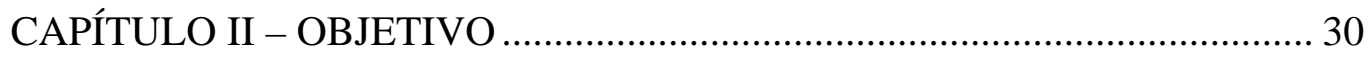

CAPÍTULO III - MATERIAIS E MÉTODOS …............................................. 32

3.1 - Caracterização das amostras de amido modificados................................. 32

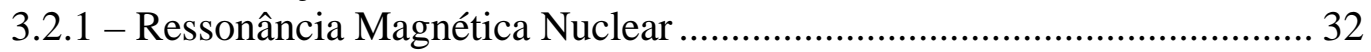

3.2.2 - Espectroscopia na Região do Infravermelho ......................................... 35

3.2.3 - Cromatografia de Permeação em Gel ................................................... 36

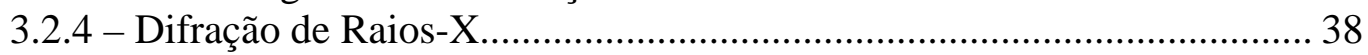

3.2.5 - Análise Elementar ................................................................................ 41

3.2 - Preparação de filmes de amido de mandioca modificados ....................... 41

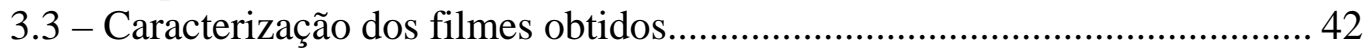

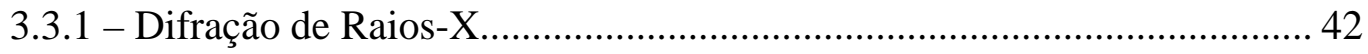

3.3.2 - Microscopia eletronica de varredura .................................................. 42

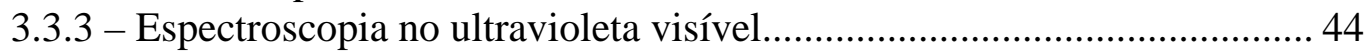

3.3.4 - Espectrocopia de impedância eletroquímica......................................... 46

3.3.5 - Análises térmicas (DSC e TGA) .............................................................. 58

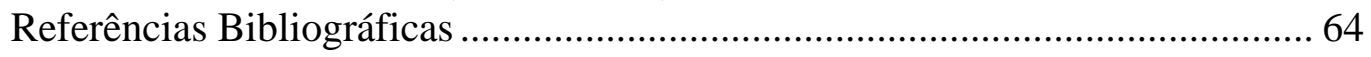

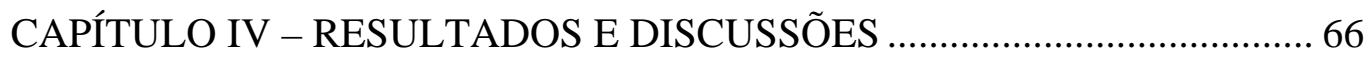

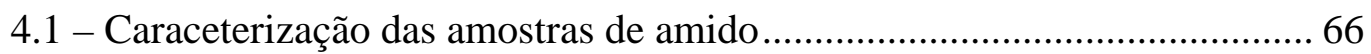

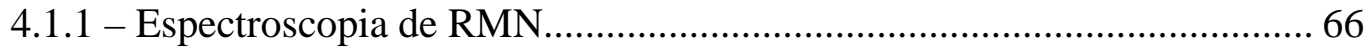

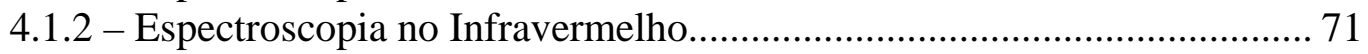

4.1.3 - Cromatografia de Permeação em Gel (GPC) .......................................... 72

4.1.4 - Determinação do Grau de Substituição.................................................. 77

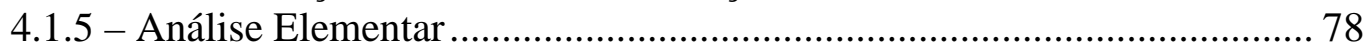

4.2 - Caracterização dos filmes de amido plastificados ................................... 79

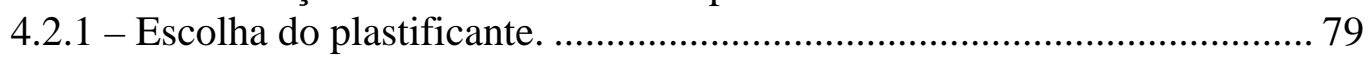

4.2.2 - Variação da quantidade de plastificante............................................... 88 
4.2.3 - Variação da quantidade de sal de lítio ................................................... 92

4.2.4 - Transparência dos ESPs a base de amido de mandioca modificado..... 104

Referências Bibliográficas ........................................................................... 106

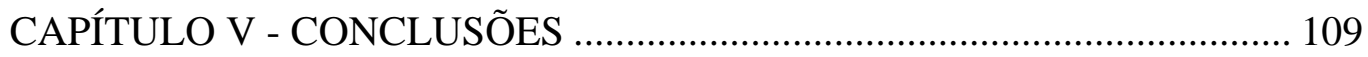




\section{LISTA DE FIGURAS}

Figura 1.1 - Modos de solvatação dos cátions ......................................................... 6

Figura 1.2 - Molécula de glicose...................................................................... 14

Figura 1.3 - Estrutura química de amilose............................................................. 14

Figura 1.4 - Estrutura química e representação de amilopectina.............................. 15

Figura 1.5 - Visualização e esquema de funcionamento de uma janela

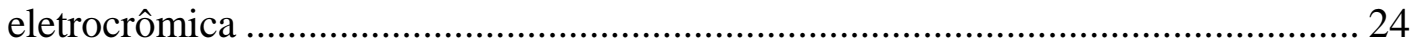

Figura 3.1 - Gráfico de difração de Raios-X, obtido do amido ............................... 40

Figura 3.2 - Representação da voltagem e corrente senoidais, a uma dada freqüência, asssociada a uma célula eletroquímica .................................................. 47

Figura 3.3 - Representação da impedância, Z, de uma célula eletroquímica no

diagrama vetorial ........................................................................................ 49

Figura 3.4 - Representação de um semicírculo com raio d..................................... 49

Figura 3.5 - Representação de um circuido RC// ................................................... 50

Figura 3.6 - Plano complexo de Nyquist para filme de amido oxidado e acetilado com $30 \%$ de glicerol e $30[\mathrm{O}] /[\mathrm{Li}]$ na temperatura de $30^{\circ} \mathrm{C}$.................................... 53

Figura 3.7 - Ajuste da curva do plano complexo de Nyquist para filme de amido oxidado e acetilado com $30 \%$ de glicerol e $30[\mathrm{O}] /[\mathrm{Li}]$ na temperatura de $30^{\circ} \mathrm{C} \ldots .54$ Figura 3.8 - Ajuste da curva do plano complexo de Nyquist para filme de amido oxidado e acetilado com $30 \%$ de glicerol e $30[\mathrm{O}] /[\mathrm{Li}]$ na temperatura de $80^{\circ} \mathrm{C} \ldots 55$ Figura 3.9 - Célula de medida utilizada nos experimentos de determinação de

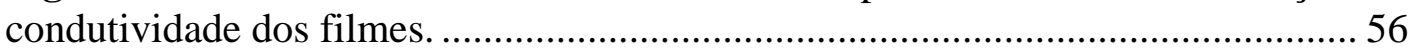

Figura 3.10 - Sistema utilizado para a realização das medidas de $\sigma$...................... 57

Figura 3.11 - Visão interna do forno. ............................................................... 58

Figura 3.12 - Curva representativa de DSC ...................................................... 59

Figura 4.1 - Estrutura química para o amido nativo ................................................. 67

Figura 4.2 - Estrutura química para o amido acetilado ............................................... 68

Figura 4.3 - Estrutura química para o amido oxidado-acetilado................................ 68

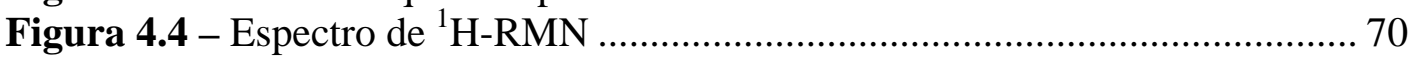

Figura 4.5 - Espectro de FT-IR amidos: nativo, oxidado e oxidado e acetilado) .. 72

Figura 4.6 - Curva de Calibração ………………………………………………... 74

Figura 4.7 - DPM do amido nativo .............................................................. 76

Figura 4.8 - DPM do amido acetilado............................................................... 76

Figura 4.9 - DPM do amido oxidado-acetilado ..................................................... 77

Figura 4.10 - Difratograma de raios-X de amido de milho rico em amilopectina plastificado com diferentes plastificantes ............................................................ 82

Figura 4.11 - Difratograma de raios-X de amido de mandioca nativo e oxidadoacetilado com diferentes plastificantes .............................................................. 83

Figura 4.12 - Comparação das condutividades com diferentes plastificantes ....... 85 Figura 4.13 - Curva de Dsc do amido oxidado-acetilado plastificado com 30\% de

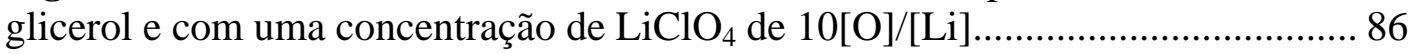
Figura 4.14 - Curva de Dsc do amido oxidado-acetilado plastificado com $30 \%$ de etileno glicol e com uma concentração de $\mathrm{LiClO}_{4}$ de $10[\mathrm{O}] /[\mathrm{Li}]$............................... 86 Figura 4.15 - Curva de Dsc do amido oxidado-acetilado plastificado com $30 \%$ de sorbitol e com uma concentração de $\mathrm{LiClO}_{4}$ de $10[\mathrm{O}] /[\mathrm{Li}]$..................................... 87 Figura 4.16 - Medidas de $\log$ da condutividade em função da concentração de glicerol para filmes de amido acetilado 
Figura 4.17 - Medidas de $\log$ da condutividade em função da concentração de plastificante para filmes de amido oxidado-acetilado.

Figura 4.18 - Difração de raios-X do amido de milho rico em amilopectina plastificado com diferentes $\%$ de glicerol em massa e com $10[\mathrm{O}] /[\mathrm{Li}]$.................. 90

Figura 4.19 - Log da condutividade em função da razão [O]/[Li] ........................ 93

Figura 4.20 - Log da condutividade em função do inverso da temperatura.. ........ 94

Figura 4.21 - Energia de ativação versus a razão $[\mathrm{O}] /[\mathrm{Li}]$.................................. 95

Figura 4.22 - $\mathrm{T}_{\mathrm{g}}$ da amostra de amido oxidado-acetilado plastificado com $30 \%$ de glicerol e contendo $30[\mathrm{O}] /[\mathrm{Li}]$. 96

Figura 4.23 - Curvas de DSC para filmes de amido nativo plastificado com 30\% de sorbitol e contendo diferentes razões de $[\mathrm{O}] /[\mathrm{Li}]$............................................ 97

Figura 4.24 - Difração de raios- $X$ dos amidos: nativo plastificado com $30 \%$ de sorbitol, acetilado plastificado com $30 \%$ glicerol, contendo diferentes concentrações de $[\mathrm{O}] /[\mathrm{Li}]$ 98

Figura 4.25 - Curvas de análise térmica (TGA) para as amostras de amido acetilado puro e plastificado com glicerol e com etileno glicol 99 Figura 4. 26 - Curvas de análise térmica (TGA) para a amostra de amido oxidadoacetilado com $30 \%$ de glicerol e contendo diferentes quantidades de sal. 100 Figura 4.27 - Curvas de TGA e as primeiras derivadas para as amostras de amido puro 101

Figura 4.28 - Curva de TGA e a primeira derivada para amostra de amido acetilado com $30 \%$ de glicerol e 10 [O]/[Li]. 102

Figura 4.29 - Temperatura de degradação dos filmes de amido acetilado com 30\% de glicerol em função da razão [O]/[Li], obtidas pelo pico da primeira derivada. 102 Figura 4.30 - Mircrografias dos filmes de amido nativo, acetilado e oxidadoacetilado com $30 \%$ de glicerol e nas concentrações de 10 e $30[\mathrm{O}] /[\mathrm{Li}]$ com aumento de 20000x 103

Figura 4. 31 - Espectros de UV-VIS para os filmes de amido nativo, acetilado e oxidado-acetilado com $30 \%$ de glicerol e contendo $[\mathrm{O}] /[\mathrm{Li}]=10$ e 30 105 


\section{LISTA DE TABELAS}

Tabela 3.1 - Equação de impedância para elementos do circuito equivalente....... 52

Tabela 3.2 - Mudanças de massa detectáveis por técnicas de TGA......................62 62

Tabela 4.1 - Deslocamento químico para os hidrogênios .................................... 70

Tabela 4.2 - Padrões utilizados para curva de calibração - GPC …....................... 73

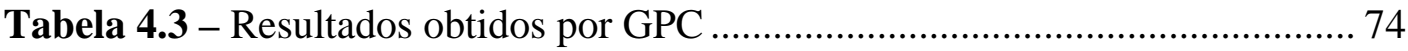

Tabela 4.4 - Teores de C, $\mathrm{H}$ e $\mathrm{O}$ do amido nativo, acetilado e oxidado-acetilado. 78

Tabela 4.5 - Valores de constante dielétric, viscosidade e a fórmula estrutural para

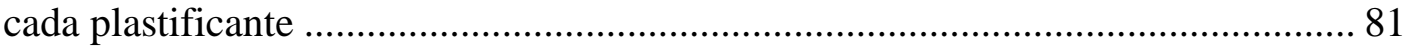

Tabela 4.6 - Valores da temperatura de transição vítrea $\left(\mathrm{T}_{\mathrm{g}}\right)$ para várias porcentagens de glicerol ................................................................................. 91

Tabela 4.7 - Valores da temperatura de transição vítrea $\left(T_{g}\right)$ para amostras de amido de mandioca acetilado, plastificado com diferentes porcentagens de

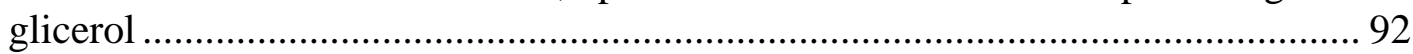

Tabela 4.8 - Espessuras dos filmes a base de amido nativo, acetilado e oxidadoacetilado com $30 \%$ de glicerol e contendo $[\mathrm{O}] /[\mathrm{Li}]=10$ e 30 106 


\section{LISTA DE ABREVIATURAS E SÍMBOLOS}

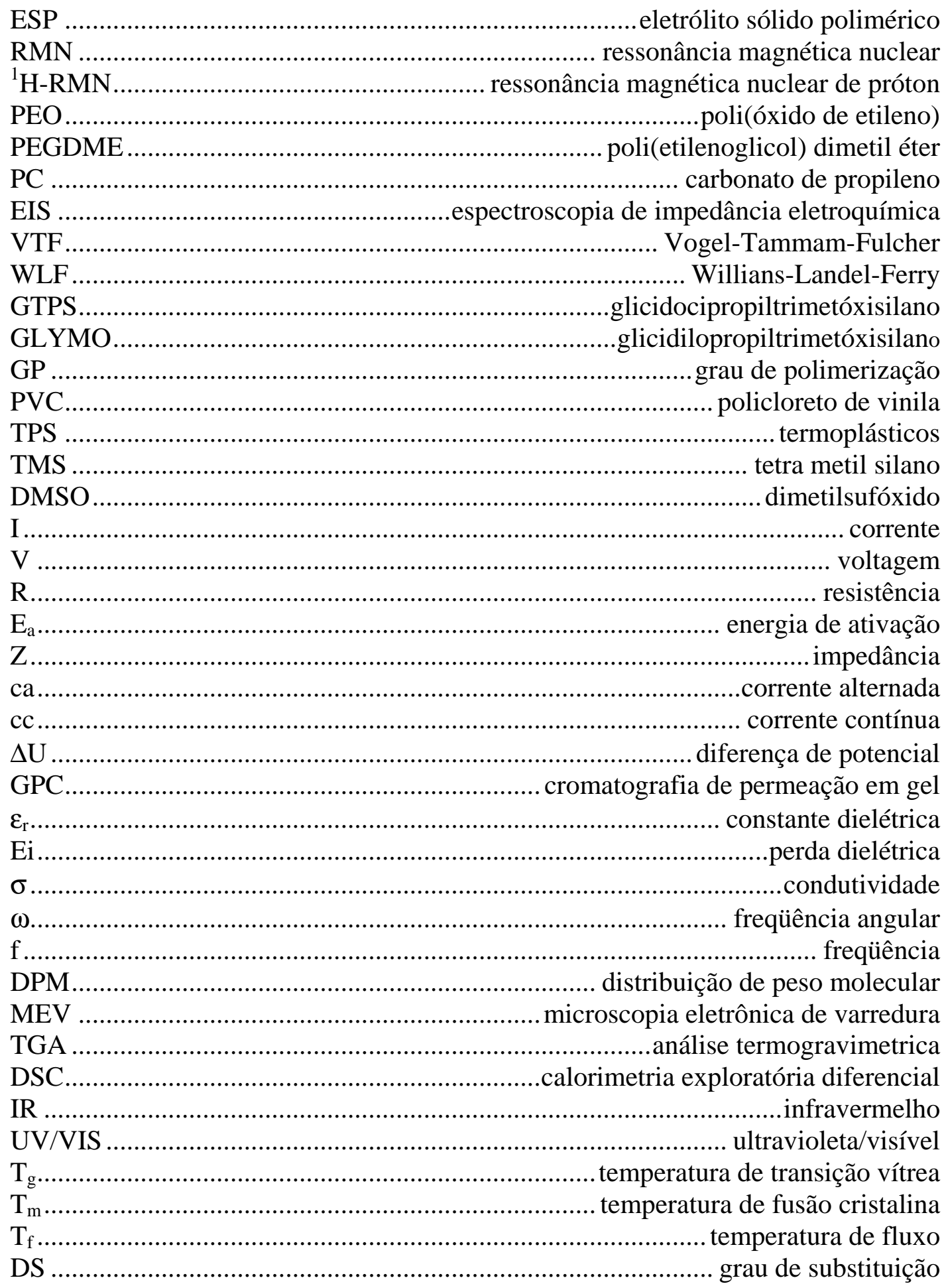




\section{RESUMO}

Esta dissertação apresenta a caracterização e o preparo de filmes a partir de amido de mandioca nativo e modificado industrialmente (amido acetilado e amido oxidado - acetilado), através da plastificação com glicerol, sorbitol ou etileno glicol.

Estes filmes foram preparados adicionando-se um sal (perclorato de lítio) com o propósito de serem utilizados como eletrólitos sólidos poliméricos (ESP), os quais apresentam grande potencial de aplicação em dispositivos eletrocrômicos, sensores e baterias, por isso os ESPs devem ser: transparentes, apresentar boa aderência e maleabilidade além de boa condutividade iônica.

As modificações conferidas ao amido foram estudadas empregando-se técnicas caracterização por espectroscopia no infravermelho, RMN e análise elementar. A distribuição de massa molecular das amostras de amido nativo e dos amidos modificados também foi estudada através da técnica de cromatografia de permeação em gel (GPC).

Os filmes foram preparados utilizando-se diferentes proporções de plastificante e de sal e em seguida com intuito de efetuar as caracterizações físicoquímicas estas amostras foram submetidas à análises de espectroscopia de impedância eletroquímica, difração de Raios-X, Microscopia Eletrônica de Varredura (MEV), análises espectrofotométricas de UV-visível, além das análises térmicas (TG e DSC). 


\begin{abstract}
This dissertation presents the preparation and characterization of films obtained from native and industrially modified (acetilate and oxidate-acetilate), cassava starches, through the plasticization with glycerol, sorbitol or ethylene glycol.

These films are prepared adding a salt (lithium perchlorate) so that they can be used as solid polymeric electrolytes (ESP), which present great application potential in electrochromic devices, sensors and batteries, therefore the films obtained must be transparent, present good adherence and flexibility besides good ionic conductivity.

The modifications of the starch were studied using techniques of characterization by infrared espectroscopy, RMN and elementary analysis. The distribution of the molecular mass of the samples of native and modified starches was also studied by means of gel permeation chromatography (GPC).

The films were prepared using different proportions of plasticizers and salt. For the physical-chemical characterization of the samples, they were subjected to analyses of electrochemical impedance spectroscopy, X-Ray diffraction, Scanning Electronic Microscopy (SEM), Uv-visible spectroscopy, besides thermal analyses (TG and DSC).
\end{abstract}




\section{Capítulo 1 - INTRODUÇÃO}

\section{1 - Eletrólitos sólidos poliméricos}

A produção, estocagem e distribuição de energia estão entre as principais preocupações da indústria e sociedade modernas. O desenvolvimento de novos materiais sólidos para aplicação como eletrólitos oferece oportunidade para criação de novos sistemas de geração e armazenamento de energia elétrica que poderão revolucionar muitas áreas da indústria. $\mathrm{O}$ desenvolvimento espacial, criação de novos tipos de memória e nova arquitetura de computadores, baterias, sensores, janelas eletrocrômicas e fotocrômicas são áreas que poderão ser beneficiadas com o desenvolvimento de condutores iônicos sólidos.

Geralmente, a condutividade iônica é associada a líquidos, mas pode ocorrer também no estado sólido como géis, cerâmicas ou polímeros. Eletrólito sólido polimérico consiste em um sal dissolvido em uma matriz (no caso o polímero) formando solução sólida condutora de íons ${ }^{1}$. Para sua aplicação como eletrólito, o polímero deve possuir algumas propriedades, tais como caráter amorfo, capacidade de solvatar íons, baixa temperatura de transição vítrea, estabilidade eletroquímica e dimensional, resistência mecânica e possibilidade de formar filmes finos ou pastilhas ${ }^{2}$. 
Os primeiros materiais utilizados para substituição dos eletrólitos líquidos foram os géis poliméricos, ou seja, materiais poliméricos com grande quantidade de plastificante adicionada à sua composição. Estes sistemas mostraram bom desempenho relacionado à alta mobilidade iônica e alta concentração de transportadores de carga. Entretanto, não possuem estabilidade química e eletroquímica adequadas ${ }^{3}$.

Os polímeros desde sua descoberta no começo do século XX sempre foram considerados como materiais isolantes e também esta propriedade, entre várias outras, era aproveitada para introdução dos polímeros na nossa vida cotidiana. Entretanto as descobertas do final do século passado demonstram que polímeros também podem conduzir tanto elétrons como íons. As pesquisas sobre polímeros condutores eletrônicos, lideradas pelos três pesquisadores: Allan MacDiarmid, Allan Heeger e T.Shirakawa, agraciados pelo premio Nobel em 2000 confirmaram a possibilidade de outras modernas aplicações de polímeros em substituição aos metais ou algumas cerâmicas. A classe destes polímeros condutores eletrônicos é bastante distinta e caracterizada pela presença de ligações duplas conjugadas além de substâncias tais como sais inorgânicos $\mathrm{FeCl}_{3}, \mathrm{AlCl}_{3}$ ou $\mathrm{I}_{2}$. Outra classe de polímeros com propriedades não isolantes são polímeros condutores iônicos descobertos pelo P.V.Wright ${ }^{4}$ em 1973 e pesquisados pelo Michel Armand ${ }^{5}$ a partir de 1978. Estes polímeros se caracterizam pelo fato de ter na sua estrutura átomos com pares de elétrons livres, no caso oxigênio, que possibilitam a interação com alguns sais inorgânicos mono ou divalentes como $\mathrm{LiClO}_{4}$ ou $\mathrm{Ca}\left(\mathrm{CF}_{3} \mathrm{SO}_{3}\right)_{2}$ entre outros. Um exemplo padrão para esta classe de polímeros é o poli(óxido de etileno) (PEO), que da mesma maneira como líquido consegue dissolver os sais mencionados acima ${ }^{6}$.

Nos últimos anos, as pesquisas têm enfatizado o desenvolvimento de eletrólitos sólidos poliméricos, ou seja, materiais que consistem em um sal dissolvido em uma matriz polimérica, que representam uma alternativa promissora para a substituição de eletrólitos líquidos e cristais 
inorgânicos, os quais podem ser aplicados em dispositivos eletrocrômicos, sensores e baterias ${ }^{1}$. A chave, para o desenvolvimento de um eletrólito sólido polimérico com condutividade iônica próxima aos eletrólitos líquidos, é incorporar estruturas características no eletrólito que aumentem a mobilidade e a concentração de portadores de carga. Assim o aumento da quantidade de sal na matriz polimérica deveria propiciar uma maior condutividade iônica, mas esta, porém não pode ser explicada somente pela quantidade de cátions introduzidos no polímero. Desta maneira, na prática a condutividade iônica aumenta com a inserção de sal somente até um valor limite. Após este máximo ocorre uma diminuição da condutividade, pois ocorre a formação dos agregados iônicos, acarretando em um aumento da viscosidade e da temperatura de transição vítrea do polímero ${ }^{7}$.

Estudos anteriores com amido de milho rico em amilopectina demonstraram resultados satisfatórios para aplicação destes filmes como eletrólitos sólidos poliméricos ${ }^{8}$. Nestes trabalhos o aumento da mobilidade dos íons no polímero tem sido feito pela adição de plastificantes. Para comprovar isso pode ser citado o trabalho de Kelly e colaboradores ${ }^{9}$, que mostraram que a condutividade do $\mathrm{PEO}-\left(\mathrm{LiCF}_{3} \mathrm{SO}_{3}\right)$ pode ser aumentada para $10^{-4} \mathrm{Scm}^{-1}$ a $40^{\circ} \mathrm{C}$, com a adição de $20 \%$ de poli(etilenoglicol) dimetil éter (PEGDME). Como o PEGDME é um éter de baixa constante dielétrica $(\varepsilon=7)$, ou seja, da mesma magnitude do PEO, não é esperado um ganho significativo nos portadores de cargas. Assim o aumento da condutividade pode ser atribuído ao aumento da mobilidade dos portadores de carga provocados pelo plastificante ${ }^{9}$. Por outro lado o plastificante carbonato de propileno (PC), tem uma constante dielétrica de 64,4 , muito maior do que do PEO. Desta maneira a sua adição no poli(óxido de etileno) pode favorecer além de aumento da mobilidade iônica também um aumento nos portadores de cargas 9 . 
A natureza do sal também influencia a condutividade do complexo polímero-sal. Em geral, os sais de lítio com anions volumosos e com baixas energias reticulares, como $\mathrm{LiClO}_{4}$, $\mathrm{LiBF}_{4}, \mathrm{LiCF}_{3} \mathrm{SO}_{3}$ e $\mathrm{LiN}\left(\mathrm{SO}_{2} \mathrm{CF}_{3}\right)_{2}$ promovem alta condutividade comparados com os haletos $\mathrm{LiCl}$ e $\mathrm{LiBr}$ que possuem relativamente alta energia reticular. A dissolução do sal de lítio no polímero ocorre quando a energia de solvatação do polímero com o $\mathrm{Li}^{+}$é maior do que a energia reticular do sal. Quando o anion é volumoso como no caso do complexo iônico, a deslocalização da carga negativa ocorre com a redução da interação íon-íon, conseqüentemente se tem um alto valor da condutividade ${ }^{10}$.

No caso do MEEP-(LiX) $)_{n}$ poly[bis-(dimetiletoxi)fosfazeno)] Shriver e colaboradores ${ }^{11}$ constataram que a condutividade aumenta com a diminuição da energia reticular do sal. Por exemplo, $\mathrm{LiBF}_{4}$ que apresenta uma energia reticular de $699 \mathrm{kJmol}^{-1}$, possui uma alta condutividade comparada com o LiSCN com uma energia reticular de $807 \mathrm{kJmol}^{-1}$. Entretanto, como o $\mathrm{LiClO}_{4}$ possui uma energia reticular de $723 \mathrm{kJmol}^{-1}$, o valor da condutividade não apresenta uma grande diferença entre $\mathrm{LiBF}_{4} \mathrm{e} \mathrm{LiClO}_{4}$, pois as energias reticulares são próximas.

Um dos parâmetros utilizados para caracterizar a capacidade de solvatação de um solvente é a constante dielétrica. Quanto maior for a constante dielétrica do solvente, maior será a habilidade em separar as cargas, diminuindo assim a probabilidade de formação de pares iônicos. Em solventes de baixa constante dielétrica, como benzeno $(\varepsilon=2,27)$, a energia de solvatação é muito baixa, desta forma é esperada a formação de pares iônicos. Para solventes com constante dielétrica menor que 7 os pares iônicos $\mathrm{AB}$ predominam sobre os íons $\mathrm{A}^{+} \mathrm{e} \mathrm{B}^{-}$, até mesmo a baixas concentrações $\left(10^{-5} \mathrm{M}\right)$. Com o aumento da concentração, a associação dos íons em solução ocorre através de um mecanismo escalonado (primeiro, $\mathrm{AB}$, então $\mathrm{ABA}^{+}$, depois $(\mathrm{AB})_{2} \mathrm{e}$ assim sucessivamente). De forma interessante, as espécies carregadas não possuem um papel tão 
importante no equilíbrio total, espécies neutras como $\mathrm{AB}$ predominam, enquanto os agregados carregados como $\mathrm{ABA}^{+}$ou $\mathrm{BAB}^{-}$são virtualmente ausentes ${ }^{12}$. Essas observações são pertinentes para o estudo dos eletrólitos poliméricos, porque para cadeias de poliéster que possuem constante dielétrica em torno de 5 a fração de sal dissolvido presente como espécie carregada pode ser bastante pequena, em completo contraste do pensamento de muitos pesquisadores, que vislumbravam íons livres flutuando em um mar polimérico. Claro que este estudo foi realizado para moléculas pequenas. A incomum habilidade de complexação dos poliéteres pode conduzir a uma formação de espécies carregadas mesmo em altas concentrações, sendo que neste caso é esperado o contrário ${ }^{7}$.

Infelizmente, não é só a constante dielétrica que pode indicar a habilidade de sovatação de um solvente. Geralmente líquidos com maior constante dielétrica são melhores solventes, entretanto o sal $\mathrm{KCl}$ se dissolve tão bem em carbonato de propileno $(\varepsilon=64,4)$ como também em 1-butanol $(\varepsilon=17,1)$. Esta discrepância indica que outros fatores também são importantes na solvatação ${ }^{7}$. As interações químicas entre os átomos são de grande valia, por exemplo, a água solvata efetivamente os ânions através de ligações de hidrogênio. Também se pode classificar um solvente através de sua capacidade de doar pares de elétrons para o soluto ${ }^{7}$.

A explicação mais aceita para a solvatação dos sais por matrizes poliméricas é demonstrada na Figura 1.1 onde os cátions $\mathrm{Li}^{+}$, formados na dissociação do sal, coordenam-se com as espécies capazes de solvatá-los i.e. átomos doadores de elétrons como, por exemplo, os oxigênios presentes na cadeia polimérica do PEO. Também estes átomos demonstram-se como os melhores candidatos, pois solvatam adequadamente as espécies responsáveis pela condução. 
(a)

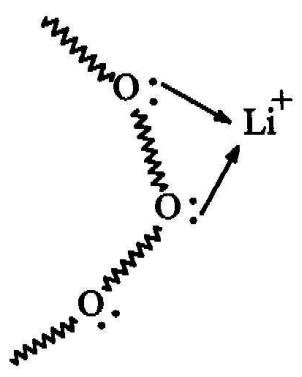

(b)

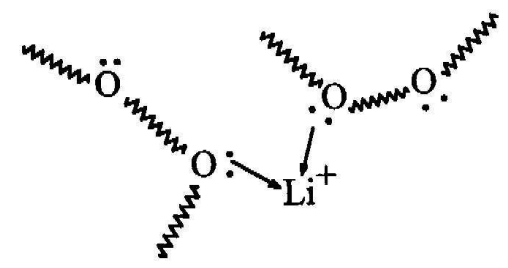

Figura 1.1 - Modos de solvatação dos cátions $\left(\mathrm{Li}^{+}\right)$pelos átomos de oxigênio de uma cadeia polimérica de PEO: (a) solvatação por uma única cadeia; (b) solvatação por duas cadeias $^{13}$.

Umas das propriedades mais citadas para eletrólitos sólidos poliméricos é o comportamento da condutividade iônica das amostras em função da temperatura. Isso fornece as informações sobre os mecanismos que governam a condutividade iônica. Quando a movimentação dos íons não resulta do compartilhamento da movimentação do polímero (matriz), ou seja, os íons "saltam" de um sítio de solvatação para outro, temos um comportamento da condutividade em função da temperatura do tipo Arrehenius. Entretanto, quando o transporte dos íons é feito com o auxílio dos movimentos da cadeia polimérica da matriz onde o sal é dissolvido, temos um comportamento com relação ao modelo VTF (Vogel-Tammam-Fulcher) e WLF

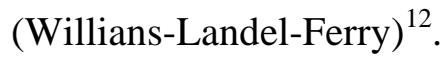

Os pesquisadores da área de eletrólitos sólidos buscam um eletrólito sólido polimérico (ESP), que combine uma ótima condutividade com boa estabilidade eletroquímica. Procurando estas qualidades, foi desenvolvido um eletrólito a base de PEO-LiPF 6 com característica de condutividade acima de $10^{-4} \mathrm{Scm}^{-1}$, para baixas concentrações de sal. Outro eletrólito a base de 
PMMA-(PC - carbonato de propileno e EC - carbonato de etileno) com $\mathrm{LiN}\left(\mathrm{CF}_{3} \mathrm{SO}_{2}\right)_{2}$, apresentou uma condutividade de $3 \times 10^{-3} \mathrm{Scm}^{-1}$, ou seja, um ótimo valor à temperatura ambiente, o qual pode ser utilizado em janelas eletrocrômicas ${ }^{14}$.

Entre inúmeros trabalhos sobre ESPs pode ser citado artigo do Furtado e colaboradores ${ }^{15}$, em que investigaram um eletrólito sólido polimérico a base de um copolímero de poli (tetrametileno glicol) (PTMG) de baixa massa molar com poli (etileno glicol) (PEG), obtendo valores de condutividade abaixo de $10^{-4} \mathrm{Scm}^{-1}$ à temperatura ambiente. Gazotti e colaboradores ${ }^{16}$, também estudaram a condutividade iônica de copolímeros de óxido de etileno/epicloridrina, contendo $\mathrm{LiClO}_{4}$. Estes pesquisadores obtiveram altos valores de condutividade, em torno de $4,1 \times 10^{-5} \mathrm{Scm}^{-1}$ à $30^{\circ} \mathrm{C}$ além de uma boa estabilidade eletroquímica.

Além dos ESPs também estão sendo intensivamente pesquisados sistemas híbridos, chamados de eletrólitos organicamente modificados (ORMOLITAS). Munro e colaboradores ${ }^{17} \mathrm{e}$ Orel e colaboradores ${ }^{18}$ descreveram dispositivos eletrocrômicos com eletrólitos obtidos da hidrólise de silanos organicamente modificados como glicidocipropiltrimetóxisilano (GPTS) ou glicidilopropiltrimetóxisilano (GLYMO). Esses condutores iônicos são constituídos por uma mistura de fases orgânicas e inorgânicas a escalas nonométricas e eles exibem além de boa condutividade também elevada transparência. Nestes sistemas ambas as fases contribuem para estas boas propriedades. Assim a condução iônica e a flexibilidade são induzidas pela faze polimérica e as propriedades mecânicas deste eletrólito são melhoradas devido à presença da rede inorgânica. Outra família promissora de Ormolitas é constituída por sílica-poli (etileno glicol) ${ }^{19}$. 


\section{2 - Eletrólitos sólidos a base de polímeros naturais}

O desenvolvimento de novos materiais tem evoluído de modo positivo ultimamente, sendo que uma preocupação, além de baixo custo, tem sido em utilizar recursos naturais e renováveis. Atualmente as indústrias buscam se adequar à exigência das novas políticas ambientais, ou seja, poluir o menos possível. Um grande problema enfrentado atualmente é a questão dos plásticos, pois demoram muito para se degradarem, deste modo, atualmente são procuradas alternativas para encontrar produtos biodegradáveis e/ou principalmente reutilizáveis para outros fins. Uma idéia bastante viável, e que vem ganhando um grande interesse dos pesquisadores, é a utilização da biomassa vegetal como matéria-prima para substituição dos polímeros sintéticos. Desta forma, além de produzir materiais biodegradáveis, os quais não poluirão o meio ambiente, eles seriam também de baixo custo comparado com as matérias-primas comumente utilizadas.

Alguns polissacarídeos e seus derivados são muito interessantes do ponto de vista industrial para obtenção tanto de materiais tradicionais como no desenvolvimento de novos materiais com propriedades específicas. Assim a celulose é utilizada para obtenção de fibras têxteis e seus derivados na indústria cosmética e de tintas devido elevadas viscosidades das suas soluções e propriedades filmógenas. O amido e a quitosana também estão ganhando cada vez mais atenção no desenvolvimento de novos materiais além das suas aplicações tradicionais na indústria alimentícia e farmacêutica respectivamente.

O Brasil produz cerca de 240 mil toneladas de lixo por dia, número inferior ao produzido nos EUA (606.000 t./dia), mas bem superior de países como a Alemanha (85.000 t./dia). Desse 
total, a maior parte vai parar nos lixões a céu aberto. Apenas uma pequena porcentagem é descartada em locais apropriados. Uma cidade como São Paulo gasta, por dia, 1 milhão de reais com a questão do lixo. Para o Instituto de Pesquisas Tecnológicas (IPT), são poucas as prefeituras locais que possuem equipes e políticas públicas específicas para o lixo. Quando não é tratado, constitui-se em sério problema sanitário, pois expõe a comunidade a doenças como diarréia, amebíase, parasitose, contaminando o solo, as águas e os lençóis freáticos ${ }^{20}$.

Entre as soluções para a questão estão à criação de aterros sanitários em locais adequados, a adoção de programas de coleta seletiva e reciclagem, a realização de campanhas de conscientização da sociedade e uma maior atuação dos poderes públicos ${ }^{20}$. A produção de materiais biodegradáveis oferece uma solução interessante para os materiais plásticos. Como para os resíduos orgânicos, tais como os alimentos, a eliminação dos materiais biodegradáveis não é automática e é considerada pelos especialistas como uma reciclagem. Os materiais biodegradáveis passam por um processo de compostagem, com a obtenção de um composto estável, considerado como o produto final da reciclagem.

Desta maneira parece bastante interessante substituir os materiais poliméricos não degradáveis e pouco recicláveis por modernos materiais biodegradáveis obtidos a partir de polímeros naturais.

\subsection{1 - Biopolímeros}

Os bioplásticos presentes no mercado são oriundos principalmente de amido, com 85 a $90 \%$ do mercado ${ }^{21}$. Entre os bioplásticos de amido incluem-se os fabricados com amidos nativos ou pouco modificados, isolados ou em conjunto com moléculas naturais ou sintéticas. Inclui-se também o resultado da polimerização do ácido lático obtido por fermentação do amido. 
$\mathrm{O}$ uso de amido para produzir bioplásticos iniciou nos anos $70^{22}$. O amido tem a vantagem de ser barato, abundante e renovável. Além disso, está presente sob várias formas em função da origem da matéria-prima ${ }^{23}$. No estado granular, foi usado como agente de enchimento para poliolefina e como componente em misturas com polímeros sintéticos. Segundo Lawter e Fischer $^{23}$, o amido foi também modificado por grafting (enxertia) com monômeros de vinil (ex: acrilato de metila), originando materiais que podem ser injetados em moldes ou extrusados.

Podem ser obtidos também termoplásticos (TPS) a partir de amido. A noção de TPS é relativamente recente e é hoje uma das principais pistas de pesquisas para produção de materiais biodegradáveis $^{24}$. O amido não é um verdadeiro termoplástico, mas na presença de um plastificante (água, glicerina, sorbitol, etc), altas temperaturas $\left(90-180^{\circ} \mathrm{C}\right)$ e cisalhamento, ele perde sua estrutura granular semicristalina e adquire comportamento similar ao de um termoplástico derretido, permitindo sua transformação em equipamentos de injeção, extrusão e sopro, como para os plásticos sintéticos ${ }^{25,26}$.

A água adicionada à formulação tem duas funções: de agente desestruturante do grânulo nativo, com rompimento das ligações de hidrogênio entre as cadeias e de plastificante. No entanto é necessária a adição de um plastificante adicional além da água, tal como um poliol, que será pouco influenciado pelas condições atmosféricas em mecanismo de sorção - desorção e que permitirá a obtenção de uma fase fundida em temperatura inferior à da degradação do amido ${ }^{26}$. Segundo Lourdin et al. ${ }^{25}$ a quantidade ideal de plastificante, tal como glicerol, sorbitol, etc., é de 20 a $40 \%$ em relação ao peso de amido. Também ele observou que o teor de plastificante apresenta relação direta com as propriedades mecânicas e a transição vítrea do material.

Entretanto a umidade provoca as variações nas propriedades mecânicas do amido. Os derivados deste produto possuem uma alta permeabilidade a umidade e degradam de forma rápida o que prejudica suas possíveis aplicações práticas. Modificações para remediar a esses 
problemas encarecem o produto final, limitando as soluções ${ }^{23}$. Para Averous et al. ${ }^{26}$, além de sensibilidade a umidade, o fato dos biopolímeros de amido apresentarem propriedades mecânicas que se alteram com o tempo, a baixa força de resistência ao impacto e no caso dos produtos termoformados, a pequena espessura dos produtos formados, limitam o uso dos derivados de amido.

\subsection{2 - Amido}

O amido é a principal substância de reserva nas plantas superiores e fornece de 70 a $80 \%$ das calorias consumidas pelo homem. A matéria-prima é disponível em quantidade suficiente e os processos industriais permitem que o amido seja extraído com elevada pureza. Trata-se de uma matéria-prima renovável, biodegradável e não tóxica ${ }^{27}$. Depois dos açúcares mais simples é o principal carboidrato que os vegetais superiores sintetizam a partir da fotossíntese. Entre as matérias-primas para sua extração destacam-se as raízes e tubérculos, como a mandioca e a batata, e os cereais como o milho, o trigo e o arroz. Tem sido tradicionalmente usado na indústria de alimentos como ingrediente ao mesmo tempo com valor calórico e melhorador das propriedades funcionais em sistemas alimentícios. Dependendo do tipo, o amido pode, entre outras funções, servir para facilitar o processamento, fornecer textura, servir como espessante, fornecer sólidos em suspensão e proteger os alimentos durante o processamento entre outros ${ }^{27}$. Deste modo, este polissacarídeo desempenha um importante papel no controle das características de um grande número de alimentos processados.

As técnicas de processamento de matérias-primas amiláceas estão entre as mais antigas. Descrições das mesmas constam da história da civilização. Foram encontradas tiras de papiros 
egípicos, coladas entre sim com uma pasta adesiva obtida de amido gomificado, datando de 4.000 -3.500 anos a.C.

Uma das primeiras descrições da extração de amido foi dada por Cato em um tratado Romano de Agricultura, escrito em 170 d. C. Por essa descrição, os grãos de cereal eram macerados com água por dez dias, a água removida e o grão moído e agitado em água potável. A mistura era deixada assentar e o material precipitado, prensado em um pano de linho. O creme semi-líquido era coletado em uma vasilha limpa e lavado com água potável. O material obtido era colocado ao sol para secar. Essa descrição é importante porque os processos modernos seguem exatamente essa ordem, mostrando que os equipamentos podem mudar, mas os princípios dificilmente são alterados.

Em 1719, Leenwenhoek, o inventor do microscópio, fez por intermédio deste aparelho, intensas observações de grânulos de amido. Esses estudos foram facilitados pelas dimensões apresentadas pelos grânulos de amido, que estão entre as maiores partículas sub-microscópicas encontradas na natureza. A partir daí muitas outras observações foram feitas e possibilitaram o avanço dos conhecimentos sobre a estrutura do amido.

Os alimentos amiláceos têm estado sempre presentes na dieta do homem. Na média mundial, $43 \%$ das calorias empregadas na alimentação humana são fornecidas por cereais. A situação do consumo de carboidratos pelos brasileiros era em média de $170 \mathrm{Kg} / \mathrm{habitante} / \mathrm{ano}$, baseada em cereais e leguminosas (trigo, milho, arroz, feijão), mas principalmente, cerca de $80 \%$ com raízes de mandioca e sua farinha, com uso quase que exclusivamente alimentar ${ }^{27}$.

As indústrias são as maiores consumidoras de amido nos países desenvolvidos, sendo que as de alimentos processados empregam o amido para diversos fins tais como espessante em sopas, caldos e molhos de carne, superfície anti absorção em frituras, ligante em embutidos de carne, formadores de gel em balas e pudins, estabilizante em molhos de saladas, etc. Já as 
indústrias têxteis garantem fios mais resistentes com goma de amido e as indústrias de papel utilizam o amido como adesivo das fibras de celulose.

O desenvolvimento das agroindústrias depende cada vez mais do conhecimento das características e propriedades do amido o qual possibilita formas corretas de utilização, aprimoramento tecnológico e busca de novos mercados. O reconhecimento da importância deste conhecimento deve-se em grande parte ao desenvolvimento de pesquisas na área de tecnologia de alimentos, para a qual têm contribuído áreas como a microbiologia, a bioquímica e a física aplicada, entre outras. Por outro lado a produção e uso de muitos tipos de amidos modificados é prática antiga em países desenvolvidos. No Brasil os amidos são modificados a partir de milho e mandioca por empresas nacionais (cerca de 70) e multinacionais, mas ainda são limitados quanto aos tipos em relação a outros países. No momento em que muitos países, principalmente na Europa, buscam amidos naturais, no Brasil, a maioria das empresas nacionais tenta iniciar a produção dos modificados.

Além dos usos já citados, o amido tem sido utilizado como matéria-prima na indústria têxtil, na elaboração de compostos famacêuticos, na produção de resinas naturais e na elaboração de materiais termoplásticos biodegradáveis. Pode ser também empregado na produção de álcoois finos para preparo de bebidas e produção de álcool carburante.

Pesquisas atuais não só têm referendado e aprofundado esses conhecimentos, como permitiram a descoberta de novas propriedades tais como: condutibilidade térmica e elétrica, cristalinidade, polaridade, que têm possibilitado a melhor utilização do amido.

$\mathrm{Na}$ estrutura química do amido, as ligações glicosídicas recebem numerações de 1 a 6 , como se apresenta na Figura 1.2. Essas numerações facilitam a compreensão das propriedades e reatividade do amido. 
O amido, que se apresenta na forma de discretos grânulos com forma e tamanho dependente da sua fonte botânica, é composto basicamente por dois tipos de macromolécluas: amilose e amilopectina (Figuras 1.3 e 1.4 respectivamente). $\mathrm{O}$ amido deve muito de sua funcionalidade a estas duas macromoléculas, assim como à organização física das mesmas dentro da estrutura granular ${ }^{28}$. A proporção entre amilose e amilopectina é variável com a fonte botânica, o que irá conferir características específicas à pasta de amido.

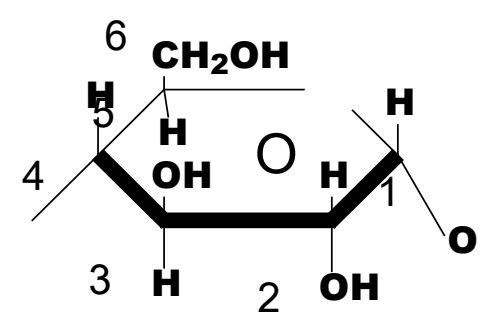

Figura 1.2 - Molécula de glicose.

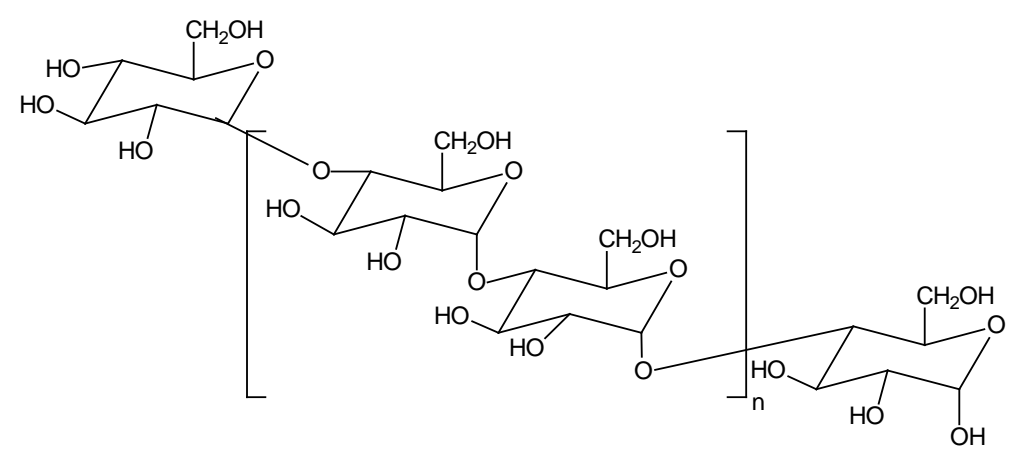

Figura 1.3 - Estrutura química de amilose. 

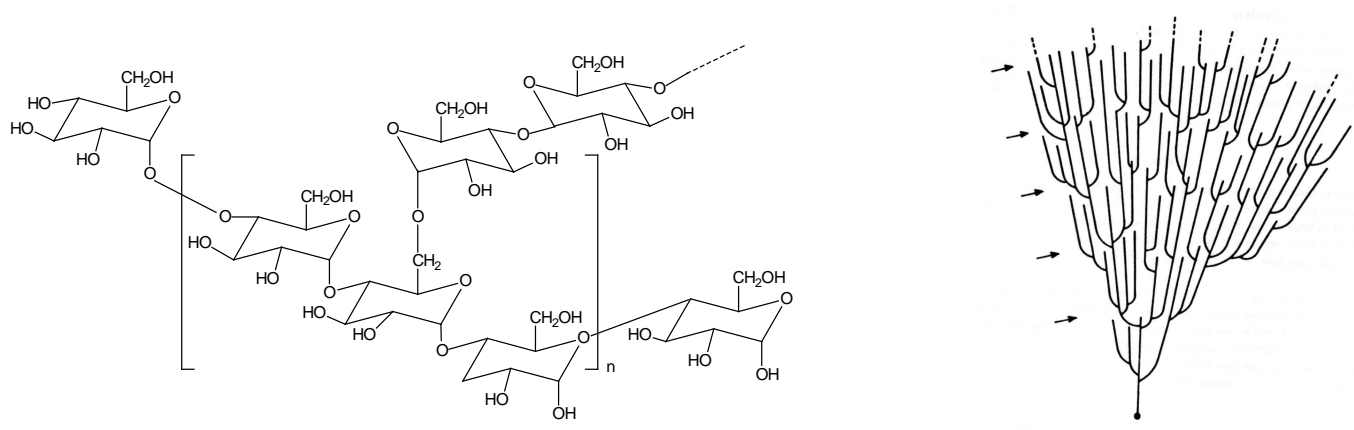

Figura 1.4 - Estrutura química e representação de amilopectina.

A amilose é uma molécula essencialmente linear formada por unidades de D-glicose ligadas em $\alpha(1 \rightarrow 4)$ com um pequeno número de ramificações ${ }^{29}$. Seu grau de polimerização (GP) é controverso e parece ser dependente do vegetal de origem e do estágio de crescimento, (French, 1984, Buléon et al. 1998) ${ }^{29,30}$ destacam que existem nos grânulos de amido moléculas de amilose estritamente lineares e outras que apresentam ramificações. Os autores comentam que estudos têm demonstrado um comportamento similar entre essas amiloses quando em solução. Independentemente de serem lineares ou não, formando um complexo com o iodo de coloração azul, diferenciando-se desta maneira da amilopectina que fica avermelhada.

A amilose apresenta peso molecular de $1,5 \times 10^{5}-10^{6}$ e tamanho médio da cadeia de aproximadamente $10^{3}$ unidades de glicose. A amilose também é instável em soluções aquosas diluídas, formando um retículo pela propriedade de retrogradação.

A amilopectina é uma molécula altamente ramificada formada por unidades de D-glicose ligadas em $\alpha(1 \rightarrow 4)$ e com 5 a $6 \%$ de ligações $\alpha(1 \rightarrow 6)$ nos pontos de ramificação ${ }^{29,}{ }^{30}$.A grande maioria dos amidos contém 20 - 30\% de amilose e 70-80\% de amilopectina e essa razão varia com a fonte botânica é composta por centenas de cadeias curtas de $(1 \rightarrow 4)-\alpha$-Dglucanas que são interligadas pelas ligações $\alpha(1 \rightarrow 6)$. A amilopectina apresenta um grau de polimerização de cerca 
de $10^{4}-10^{5}$, peso molecular da ordem de $(50-500) \times 10^{6}$ e o comprimento das ramificações é variável mas é comum apresentarem entre 20 e 30 unidades de glicose em presença de iodo a amilopectina dá coloração avermelhada e é estável em soluções aquosas diluídas ${ }^{28}$.

A estrutura fina da amilopectina tem sido assunto de pesquisas durante os últimos anos. Vários modelos estruturais têm sido propostos para explicar o modo das cadeias unitárias arranjarem-se para proporcionar estrutura altamente ramificada ${ }^{30,31}$.

Os grupos hidroxila presentes nas moléculas de glicose conferem ao amido uma característica aniônica fraca. Segundo Oosten ${ }^{32}$, o pK da amilose é de 12,6, portanto menor que o da água que é de 14,0. Segundo esse autor o valor para a amilopectina seria idêntico ao da amilose. Quando o amido puro é suspenso em água à concentração de íons hidrogênio original na fase aquosa é de $10^{-7}$ e dentro das partículas de amido é um pouco maior, assim uma certa quantidade de íons hidrogênio migrarão para a fase aquosa em função do gradiente de concentração. Quando esses íons hidrogênio deixarem o amido, este adquirirá cargas negativas e a fase aquosa cargas positivas.

O amido puro tem coloração branca, é insípido e se adicionado à água fria e mantido sob agitação forma uma suspensão de aspecto leitoso, separando-se após repouso. Embora tendo-se verificado que pequena fração torna-se solúvel quando agitado em água, é tido como praticamente insolúvel. Baseado nisto é que a indústria consegue obtê-lo em estado puro.

O amido é opticamente ativo, desviando a luz polarizada para a direita (dextrógiro sendo $(\alpha)^{+}=205$. Este desvio varia de intensidade de acordo com a planta de que procede, possibilitando identificação da origem botânica e quantificação em laboratório. 


\subsection{3 - Amido de mandioca modificado}

Para preencher as várias demandas para funcionalidades em produtos amiláceos diferentes, o amido processado industrialmente pode ser modificado enzimaticamente, fisicamente ou quimicamente.

$\mathrm{Na}$ maioria das modificações químicas do amido, normalmente referidas como derivatizações químicas, a forma granular é mantida e grupos hidroxilas são parcialmente substituídos produzindo éteres ou ésteres de amido, assim como amidos aniônicos e catiônicos. Outros tipos de derivações químicas são: a oxidação, formação de ligações cruzadas e a enxertia (grafting). Uma grande quantidade de amidos modificados é usada nos setores alimentícios e não alimentícios com perfis de aplicação direcionados empiricamente.

Atualmente, na busca por (novas) aplicações de polissacarídeos (modificados), e do amido, em particular, a pesquisa segue a estratégia do "desenvolveimento sustentável".

Um passo essencial das pesquisas é o desenvolvimento de produtos que atendam as necessidades dos consumidores. Muitos autores relatam algumas das características esperadas do amido para uso nas indústrias alimentícias.

A estrutura macro molecular do amido lhe confere propriedades particulares, tais como solubilidade, viscosidade, poder de gelatinização ou de adesão. Atualmente, as empresas de alimentos recorrem ao uso de amidos modificados. Do amido até a glicose, todos os produtos podem passar por reações de modificação e de conversão, conduzindo à produção de moléculas de graus de complexidade variados. As razões que levam à modificação são:

- Modificar as características de cozimento (gelatinização); 
- Diminuir a retrogradação;

- Reduzir a tendência das pastas em formarem géis;

- Aumentar a estabilidade das pastas ao resfriamento e congelamento;

- Aumentar a transparência das pastas ou géis;

- Melhorar a textura das pastas ou géis;

- Melhorar a formação de filmes;

- Aumentar a adesão;

- Adicionar grupamentos hidrofóbicos e introduzir poder emulsificante.

Desta maneira o presente trabalho mostra a possibilidade de preparação de eletrólitos sólidos poliméricos (ESP) a partir de diferentes amidos modificados e plastificados visando sua prática aplicação em dispositivos eletrocrômicos.

Para o desenvolvimento destes novos ESPs foram utilizados dois tipos de amido de mandioca modificados, ambos produtos industriais fornecidos pela AVEBE do Brasil.

O amido acetilado - obtido a partir da esterificação com anidrido acético ou acetato de vinila:
Am.- $\mathrm{CH}_{2} \mathrm{OH}+$ anidrido acético $\rightarrow$
Am.O- $\mathrm{COCH}_{3}+\mathrm{CH}_{3} \mathrm{COOH}$
(Amido)
ou acetato de vinila
(am. acetilado)
ác. acético 
O amido oxidado e acetilado - obtido pelo tratamento com hipoclorito de sódio e, posteriormente, esterificado com anidrido acético:

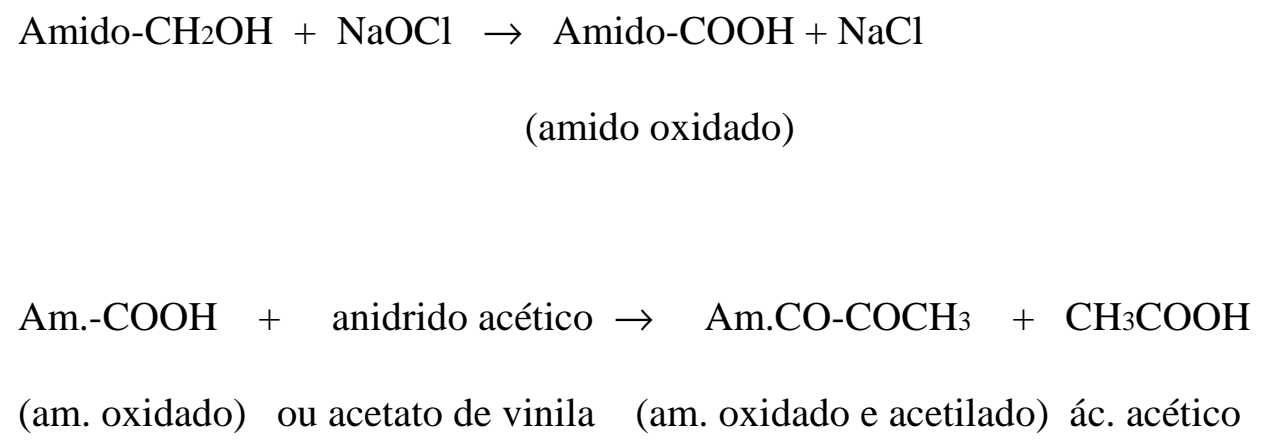

\section{3- Plastificantes}

Um plastificante é definido pela União Internacional de Química Pura e Aplicada (IUPAC) como sendo uma substância incorporada em um material para aumentar sua flexibilidade e manuseio. Desta maneira um plastificante pode diminuir o ponto de fusão, abaixar a temperatura de transição vítrea $\left(\mathrm{T}_{\mathrm{g}}\right)$ e diminuir a cristalinidade do material ao qual foi incorporado. Os plastificantes, em sua maioria, são líquidos de baixa volatilidade e viscosidade. Em muitas circunstâncias, eles são misturados para fornecer uma ampla escala de propriedades físicas em um único polímero ${ }^{33}$.

Os plastificantes são aditivos largamente empregados em alguns tipos de materiais poliméricos, com o objetivo de melhorar a processabilidade deles e aumentar sua flexibilidade. Em muitas circunstâncias, eles são adicionados para obtenção de ampla escala de propriedades físicas em um único polímero.

Em termos práticos, a plastificação (ou plasticização) consiste em adicionar o plastificante através de mistura física com as moléculas do polímero para alterar a viscosidade do sistema, 
aumentando a mobilidade das macromoléculas. Os plastificantes podem ser sólidos ou, como na maioria dos casos, líquidos de baixa volatilidade (alto ponto de ebulição).

Tem sido postulado que a adição do plastificante reduz as forças intermoleculares dos polímeros e aumenta o volume livre. As principais considerações para a seleção de um plastificante com a finalidade de modificar as propriedades de um sistema polimérico são: compatibilidade, permanência e envelhecimento, além de outros. O plastificante deve permanecer na mistura durante o tempo de vida útil do produto. Um plastificante deve ser capaz de se misturar uniformemente e homogeneamente e permanecer no polímero mesmo quando resfriado ou aquecido moderamente assim como em temperatura ambiente. $\mathrm{O}$ plastificante não pode migrar do material devido à volatilidade, extração ou outras influências do ambiente. Assim para escolher um plastificante deve-se considerar a sua eficiência para modificar as propriedades desejáveis, tão bem como aperfeiçoar os efeitos em outras propriedades.

Devido ao papel e o propósito de um plastificante em um sistema polimérico serem bem definidos, é fácil entender quais são os materiais poliméricos que utilizam plastificantes para modificar suas propriedades físicas, para as suas aplicações desejadas. O poli(cloreto de vinila) (PVC) e seus copolímeros são os que mais utilizam plastificantes para ampliar suas propriedades físicas e de aplicação. Derivados de celulose dependem dos plastificantes com a finalidade de diminuir a temperatura de fusão para temperaturas bem abaixo da sua degradação, tornando assim o material processável ${ }^{34}$.

Os plastificantes podem ser classificados pela massa molar, estrutura molecular, compatibilidade, eficiência ou propósito de aplicação. De um ponto de vista analítico, os plastificantes podem ser classificados pelas suas estruturas moleculares porque a estrutura molecular está diretamente relacionada com a polaridade e flexibilidade molecular, nas quais afetarão suas propriedades. Na escolha do plastificante é preciso considerar sua eficiência em 
modificar as propriedades desejadas, tanto quanto a sua influência sobre outras propriedades. Desta forma, as transições que podem ocorrer nos materiais poliméricos são importante fator a ser conhecido quando se trabalha com plastificantes, pois seu desempenho está intimamente ligado a essa variável.

Há um grande interesse comercial em obter eletrólitos sólidos poliméricos com altos valores de condutividades $\left(\geq 10^{-5} \mathrm{Scm}^{-1}\right)$, com a finalidade de utilizá-los em baterias de lítio ou em dispositivos eletrocrômicos. Dessa forma, foi descoberto em recentes estudos, que a adição de plastificantes polares capazes de formar um complexo com o íon lítio, favorece um aumento na condutividade iônica dos eletrólitos ${ }^{35,36,37}$. Além de plastificar o polímero, o plastificante, geralmente uma substância de baixa massa molar, tem como principal função separar as cargas (íons) que estão complexadas com o polímero e promover uma dissociação do sal, contribuindo assim para a condutividade iônica do eletrólito.

A incorporação de plastificante no amido tem sido explorada por crescente interesse no aumento a biodegradação do plástico, reduzindo assim, a quantidade de plástico que vai para o lixo e desta maneira polui o meio ambiente. Amido plastificado pode ser usado na fabricação de cápsulas, sacos de lixo, potes para flores, e em produtos menos óbvios como ossos-brinquedos artificiais para cachorros, e muitos outros itens disponíveis. Embora o amido plastificado seja produzido comercialmente, o conhecimento científico sobre ele é limitado, especialmente no que concerne a relação entre processo, estrutura e propriedades ${ }^{34}$.

Mudanças estruturais e nas propriedades do amido plastificado, acontecem com o passar do tempo em seu estado gelatinoso, através da retrogradação, em que há uma reorganização das moléculas do amido em estruturas mais ordenadas. As taxas de retrogradação e cristalização dependem do conteúdo de plastificante e são relacionadas à temperatura de transição vítrea ${ }^{34}$. 
A taxa de cristalização é influenciada pela quantidade de amilose, fonte de amido e condições de armazenamento. A cristalização da amilose é mais rápida comparada com a da amilopectina e podem ser intramolecular ou intermolecular. Co-cristalização da amilopectina com amilose que foi sugerido para a retrogradação de géis de amido, provavelmente também acontece $^{34}$.

Durante mudanças estruturais que acontecem ao passar do tempo, o conteúdo de plastificante no amido afeta a razão de cristalização. Altas quantidades de plastificante causam um aumento na mobilidade das cadeias do amido diminuindo a temperatura de transição vítrea ${ }^{38}$. A taxa de cristalização aumenta com o aumento do conteúdo de água. Reciprocamente, glicerol reduz a taxa de cristalização a uma quantidade de água constante devido à interação amidoglicerol. Entretanto, devido ao glicerol ser higroscópico, a quantidade de água normalmente aumenta, assim diminuindo a temperatura de transição vítrea e aumentando a taxa da cristalização.

\section{4- Dispositivos eletrocrômicos}

Dispositivos eletrocrômicos são a aplicação prática do fenômeno de eletrocromismo. Este fenômeno é definido como mudança reversível de coloração de material, no caso do óxido de tungstênio de transparente para o azul escuro, causada pela aplicação de corrente ou potencial elétrico $^{39}$.

Os dispositivos eletrocrômicos vêm sendo muito estudados por apresentarem várias vantagens em relação às janelas ou visores de cristais líquidos. Estas vantagens seriam: alto contraste óptico com contínua variação de transmitância e independência em relação ao ângulo de 
visão, memória óptica, estabilidade aos raios ultravioleta, além de ampla operação nas mais variadas faixas de temperatura ${ }^{40}$.

As quatro principais aplicações na área de dispositivos eletrocrômicos são:

- janelas eletrocrômicas: para controle da transmissão, aos ambientes internos, de comprimentos de ondas que variam desde o ultravioleta ao infravermelho próximo ${ }^{41}$,

- displays,

- retrovisores com reflexão variável para aplicação em veículos como exemplo do modelo Vectra e Omega GM+2 e

- superfícies com emissão térmica variável para refletir no infravermelho.

Os dispositivos eletrocrômicos típicos geralmente são constituídos por cinco camadas denominadas na seqüência: vidro/CT/CE/CI/RI/CT/vidro, como mostrado na Figura 1.5. As abreviações significam: CT - um condutor transparente, geralmente filmes finos de ITO (óxido de estanho dopado com índio) ou FTO (óxido de estanho dopado com flúor), CE - filme eletrocrômico (eletrodo de trabalho constituído por filme fino de $\mathrm{WO}_{3}$ ), $\mathrm{CI}$ - condutor iônico e RI - filme reservatório dos íons ou contra-eletrodo. A montagem destes dispositivos é feita geralmente através da deposição separada das camadas CE e RI sobre os substratos que são constituídos de vidro recoberto com CT. No final as duas partes são unidas através de um condutor iônico, objetivo deste trabalho, e seladas a fim de isolar do ambiente e umidade externas. A mudança de coloração do dispositivo ocorre quando é aplicada a diferença do potencial ao mesmo. Assim a camada eletrocrômica muda de coloração de transparente para geralmente azul devido à dupla injeção no seu interior de íons de lítio e elétrons ${ }^{39}$. 


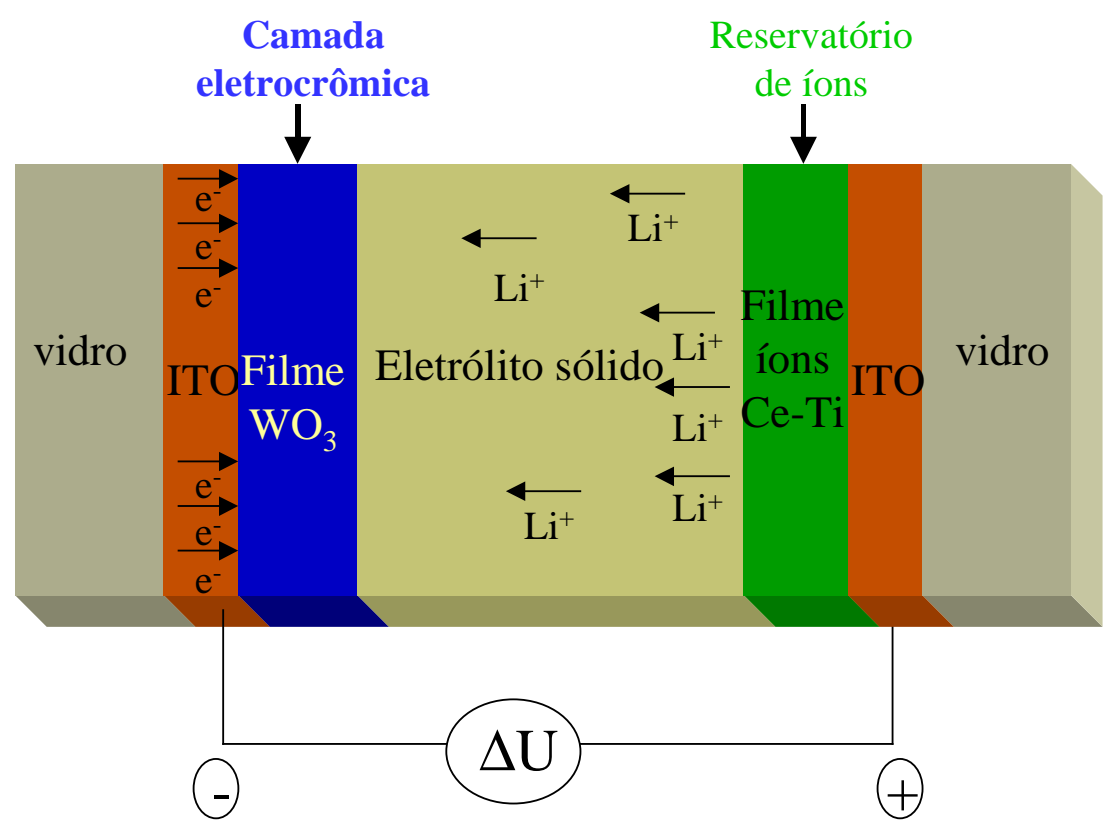

Figura 1.5 - Visualização e esquema de funcionamento de uma janela eletrocrômica.

Dependendo dos materiais utilizados os dispositivos eletrocrômicos podem trabalhar no modo de reflexão, como no caso de displays ou espelhos retrovisores ou no modo de transmissão como as janelas o que é assunto de pesquisa de vários laboratórios tanto industriais como científicos ${ }^{41,42}$. Como exemplo pode ser citado o trabalho de Munro e colaboradores ${ }^{17}$ que desenvolveram uma interessante janela eletrocrômica constituída por ITO/ $\mathrm{WO}_{3} / \mathrm{Li}^{+}-$ eletrólito/ $\mathrm{CeO}_{2}-\mathrm{TiO}_{2} / \mathrm{ITO}$. Esta janela apresentou uma ótima variação na transmitância, de $60 \%$, entre o estado colorido e transparente.

As janelas eletrocrômicas, também chamadas de "janelas inteligentes“, por permitirem alterações da transmissão e reflexão da luz, têm ampla variedade de aplicações. O mercado potencial para dispositivos inteligentes é enorme. Os primeiros produtos comercializados foram espelhos retrovisores eletrocrômicos para automóveis, os quais automaticamente diminuem a reflexão da luz quando uma luz de alta intensidade incide sobre os olhos do motorista. Indústrias 
japonesas estão produzindo óculos eletrocrômicos que atuam tanto em ambientes claros como em escuros, graças a um sistema de baterias embutido na haste dos óculos ${ }^{43}$.

No campo da arquitetura, há possibilidade da aplicação das janelas eletrocrômicas para regulagem da luminosidade e calor em ambientes fechados, diminuindo assim, o consumo de energia gasto por lâmpadas e aparelhos de ar-condicionados. Nos meses de verão, a janela eletrocrômica pode minimizar a passagem dos raios ultravioleta e infravermelho diminuindo assim o aquecimento dos ambientes internos sendo que no inverno acontece o inverso. Isso demonstra que a pesquisa no campo de desenvolvimento de eletrólitos sólidos poliméricos para aplicação em dispositivos eletrocrômicos além de ser interessante do ponto de vista científico, também, pode ser benéfica à população. 


\section{Referências Bibliográficas}

1 APPETECCHI, G. B.; DAUTZENBERG, G.; SCROSATI, B. Anew class of advanced polymer electrolytes and their relevance in plastic-like, rechargeable lithium batteries. Journal of the Electrochemical Society, v. 103, n.1, p. 6-12, 1996.

2 WARD, I. M.; BODEN, N.; CRUICKSHANK, J.; LENG, S. A. NMRstudies of ionic mobility and molecular mobility in polymer electrolytes. Electrochimica Acta, v. 40, n. 13-14, p. 20712076, 1995.

3 FAUTEAUX, D.; MASSUCO, A.; McLIN, M. VAN BUREN, M.; SHI, J. Lithium polymer electrolyte rechargeable battery. Electrochimica Acta, v. 40, n. 13-14, p. 2185-2190, 1995.

4 MACDONALD, J. R. Impedance Spectroscopy. New York: Wiley, 1987. 346p.

5 WRIGHT, P. V. Electrical conductivity in ionic complexes of poly (ethylene oxide). British Polymer Journal, v. 7, p. 319 - 327, 1975.

6 MAGISTIS, A.; SINGH, K. PEO-based polymer electrolytes. Polymer International, v. 28, p. 277-280, 1992.

7 WARD, I. M.; BODEN, N.; CRUICKSHANK, J.; LENG, S. A. NMR studies of ionic mobility and molecular mobility in polymer electrolytes. Electrochimica Acta, v. 40, n. 13-14, p. 2071 2076, 1995.

8 DRAGUNSKI, D. C. Preparação de eletrólitos sólidos poliméricos a partir do amido. 2003. 163f. Tese (Doutorado) - Instituto de Química de São Carlos, Universidade de São Paulo, São Carlos, 2003.

9 KELLY I.E., OWEN, J.R.; STEEL, B.C.H. Journal Power Sources, v.14 n. 13, 1985. 
10 THE MERCK Index: an Encyclopedia Of Chemicals, Drugs, and Biologicals. 13ed. Whiehouse Station, Merck Research Laboratories, 2001. p. 3832.

11 BLONSKY P.M.; SHRIVER, D.F., AUSTIN; P.; ALLCOCK, H.R. Solid State Ionics, v. 1819, p. 258, 1986.

12 MAGISTRIS, A.; MUSTARELLI, P.; QUARTARONE, E.; TOMASI, C. Transport and thermal properties of (PEO)(n)-LiPF6 electrolytes for super-ambient applications. Solid State Ionics, v.136 -137, p.1241-1247, 2000.

13 REGIANI, A. M. Eletrólitos Sólidos Poliméricos à base de polissacarídeos: Síntese e caracterização. 2000. Tese (Doutorado) - Instituto de Química de São Carlos, Universidade de São Paulo, São Carlos 2000.

14 OREL, B.; KRASOVEC, U.O.; STANGAR, U.L.; JUDEINSTEIN, P. All sol-gel electrochromic devices with $\mathrm{Li}+$ ionic conductor, WO 3 electrochromic films and $\mathrm{SnO} 2$ counterelectrode films. Journal of Sol-Gel Science and Technology, v. 11, n. 1, p. 87-104, 1998.

15 FURTADO, C. A.; SILVA, G.G.; PIMENTA, M.A.; MACHADO, J.C. Conductivities, thermal properties and Raman estudies of poly9tetramethylene glycol) based polymer electrolytes. Electrochimica Acta, v. 43, n.10-11, p. 1477-1480, 1998.

16 GAZOTTI, W.A. ; SPINACE M.A.S. ; GIROTTO EM, DE PAOLI, M. A. Polymer electrolytes based on ethylene oxide-epichlorohydrin copolymers. Solid State Ionics, v. 130, n. 3-4, p. 281-291, 2000.

17 MUNRO, B.; CONRAD, P.; KRAMER, S.; SCHMIDT, H.; ZAPP, P. Development of electrochromic cells by the sol-gel process. Solar Energy Material and Solar Cells, v. 54, n. 1-4, p. 131-137, 1998. 
18 OREL, B.; KRASOVEC, U.O.; STANGAR, U.L.; JUDEINSTEIN, P. All sol-gel electrochromic devices with $\mathrm{Li}+$ ionic conductor, WO 3 electrochromic films and $\mathrm{SnO} 2$ counterelectrode films. Journal of Sol-Gel Science and Technology, v. 11, n. 1, p. 87-104, 1998.

19 DAHMOUCHE, K.; ATIK, M.; MELLO, N.C.; BONAGAMBA, T.J.; PANEPUCCI, H.; AEGERTER, M.A.; JUDEINSTEIN, P. Investigation of new ion-conducting Ormolytes: Structure and properties. Journal of Sol-Gel Science and Technology, v. 8, n. 1-3, p. 711-715, 1997.

20 ALMANAQUE ABRIL. Brasil e Mundo. São Paulo: Editora Abril, 2002. (edição, 28)

21 BASTIOLI, C. Global status of the production of biobased packaging materials. In: THE FOOD BIOPACK CONFERENCE, 2000, Copenhagen. Proceedings Copenhagen, p. 2-7, 2000.

22 CURVElo, A. A.; CARVALHO, A. J.F. de; AGNELLI, J. A. M. Thermoplastic starchcellulosic fibers composites: preliminary results. Carbohydrate Polymers, Barking, v. 45, p. 183-188, 2001.

23 LAWTER, M. ; FISCHER, G. Potential of starch based pachaging for the food industry. Conference Proceedings: FOOD BIOPACK CONFERENCE, 2000, Copenhagen. Proceedings Copenhagen, p. 8-11, 2000.

24 da RÓZ, A. L. O futuro dos plásticos: biodegradáveis e fotodegradáveis. Polímeros: Ciência e Tecnologia. v. 13, n. 4, p. 5, 2003.

25 LOURDIN, N. et al. Polymères biodégradables: mise en oeuvre et propriétés de 1'amidon. Caoutchoucs et Plastiques, n. 780, 1999. 
26 AVEROUS, L. Etude de systèmes polymers multiphases: approche des relations matériauxprocédés-propriétés. Habilitation à diriger des recherches, Reims: Université de Reims, Champagne-Ardenne,. 2002. 46p

27 CEREDA, Marney Pascoli (coord). Culturas de tuberosas amiláceas latino-americanas: Propriedades gerais do amido. São Paulo: Fundação Cargill, 2002. v. 1

28 BILIADERIS, G.G. The structure and interactions of starch with food. Canadian. Journal of Physiology and Pharmacology, v. 69, p. 60-78, 1991.

29 BULEON A.; COLONNA, P.; PLANCHOT, V.; BALL, S. G.; International Journal of Biological Macromolecules, v. 23, p. 85-112, 1998.

30 FRENCH, D. Organization of starch granules. Starch Chemistry and Technology. 2. ed. New York: Academic Press; p. 184-242, 1984.

31 MANNERS, D. J., MATHESON, N. K. The fine structure of amylopectin. Carbohydrate Research. v. 90, p. 99-109, 1981.

32 OOSTEN, B. J. Interactions between starch and electrolytes. Starch/Staerke v. 42, p. $327-330,1990$.

33 WANG, F.C.Y. Polymer additive analysis by pyrolysis-gas chromatography I. Plasticizers. Journal of Chromatography A, v. 883, n. 1-2, p. 199-210, 2000.

34 LORCKS, J. Properties and applications of compostable starch-based plastic material. Polymer Degradation and Stabability, v. 59, n. 1-3, p. 245-249, 1998.

35 CHUNG, S.H.; HEITJANS, P.; WINTER, R.; BZÄUCHA, W.; FLORAJANCZYK, Z.; ONODA, Y. Enhancement of ionic conductivity by the addition of plasticizers in cationic monoconducting polymer electrolytes. Solid State Ionics, v. 112, n. 1-2, p. 153-159, 1998. 
36 KUMAR, G. G.; MUNICHANDRAIAH, N. Effect of plasticizers on magnesiumpoly(ethyleneoxide) polymer electrolyte. Journal of Electroanalytical Chemistry, v. 495, n. 1, p. 42-50, 2000.

37 XU, W.; SIOW, S. K.; GAO, Z.; LEE, S. Y. Electrochemical characterization of plasticized polyelectrolyte based on lithium- $N$ (4-sulfophenyl) maleimide. Electrochimica Acta, v. 44, n. 13, p. 2287-2296, 1999.

38 MATHEW, A. P.; DUFRESNE, A. Plasticized waxy maize starch: effect of polyols and relative humidity on material properties, Biomacromolecules. v. 3, n. 5, p. 1101-1108, 2002.

39 OLIVEIRA, S. C.; TORRESI, R. M. Uma visão das tendências e perspectivas em eletrocromismo: a busca de novo materiais e desenhos mais simples. Química Nova, v. 23, n. 1, p. 79-87, 2000.

40 ZOPPI, R. A., NUNES S. P., Polímeros: Ciência e Tecnologia, v. 4, p. 27, 1997.

41 MACEDO, M.A. Preparação e caracterização de filmes finos sol-gel para dispositivos eletrocrômicos. 1994. Tese (Doutorado) - Instituto de Física de São Carlos, Universidade de São Paulo, São Carlos, 1994.

42 AVELLANEDA, C.A.O. Desenvolvimento de janelas eletrocrômicas preparadas pelo processo sol-gel. 1999. Tese (Doutorado) - Instituto de Física de São Carlos, Universidade de São Paulo, São Carlos, 1999.

43 OLIVEIRA, S.C. Estudo espectroeletroquímico da decomposição de bismuto em meio geleificado: construção de dispositivo eletrocrômico de transmitância variável. 2003. Tese (Doutorado) - Instituto de Química de São Carlos, Universidade de São Paulo, São Carlos, 2003. 


\section{Capítulo 2 - OBJETIVOS}

Os principais objetivos deste trabalho foram: a preparação e caracterização de eletrólitos sólidos poliméricos a partir de amido de mandioca modificado, visto que trabalhos anteriores desenvolvendo eletrólitos à base de amido de milho rico em amilopectina são muito promissores devido aos seus ótimos valores das condutividades iônicas, baixo custo, boa estabilidade eletroquímica, boa transparência na região visível e fácil preparação.

Para obter melhores valores de condutividade iônica das amostras plastificadas, o objetivo foi à escolha do melhor plastificante e em seguida estudo da influência das porcentagens de glicerol (melhor plastificante) e de sal de lítio sobre a condutividade iônica.

Com intuito de verificar as diferenças no comportamento físico-químico das amostras de amidos modificados, devido à presença de átomos de oxigênio adicionais, foram efetuadas análises de condutividade iônica comparativas entre amido de mandioca nativo e os amidos de mandioca modificados: acetilado e acetilado-oxidado. 


\section{Capítulo 3 - MATERIAIS E MÉTODOS}

\section{1 - Caracterização das amostras de amido de mandioca}

Os amidos utilizados neste trabalho foram: amido de mandioca nativo e amidos de mandioca modificados: amido acetilado e amido oxidado-acetilado. Estas amostras foram gentilmente cedidas pela empresa AVEBE do Brasil, sendo utilizados da forma como foram recebidos. A modificação química destes amidos é feita pela própria empresa e o controle efetuado sobre essas modificações é através da medida de viscosidade. As amostras foram caracterizadas e utilizadas na preparação dos filmes para aplicação como eletrólitos sólidos poliméricos.

\subsection{1 - Ressonância Magnética Nuclear}

A espectroscopia de ressonância magnética nuclear (RMN) é basicamente uma outra forma de espectroscopia de absorção, semelhante à espectroscopia de infravermelho e ultravioleta.

O aparecimento em 1953 do primeiro espectrômetro comercial de RMN tornou possível utilizar a RMN como técnica analítica. Todos os instrumentos acima de $100 \mathrm{MHz}$ baseiam-se em magnetos supercondutores resfriados com hélio e operam no modo pulsado com transformada de 
Fourier. Os outros requisitos básicos, com relação aos valores de campo altos, são a estabilidade e a homogeneidade do campo de radiofreqüência .

RMN baseia-se na alteração do número quântico spin em função de um campo magnético externo. Para se obter um espectro de RMN de uma amostra, esta é colocada no campo magnético no espectrômetro e um campo de radiofrequiência é aplicado, passando-se uma corrente por uma serpentina que envolve a amostra. O campo magnético é aumentado aos poucos e a excitação ou a "oscilação" dos núcleos de uma orientação para outra é detectada como uma voltagem induzida, resultando da absorção de energia do campo de radiofreqüência. Um espectro de RMN é um gráfico de voltagem induzida contra a varredura do campo magnético. A área sob um "pico" depende do número total de núcleos que estão oscilando.

A partir do espetro de RMN, o número, natureza e "ambiente" dos ${ }^{1} \mathrm{H}$ e ${ }^{13} \mathrm{C}$ em uma molécula pode ser determinado, desta forma, pode-se deduzir a estrutura do esqueleto molecular.

Os espectros são registrados em forma de picos, cujas áreas são proporcionais ao número de hidrogênios que eles representam. As áreas dos picos são medidas por um integrador eletrônico que traça uma linha em degraus cujas alturas são proporcionais às áreas dos picos. A contagem dos hidrogênios a partir da integração é útil para determinar ou confirmar fórmulas moleculares, detectar picos sobrepostos, determinar a pureza de amostras e efetuar análises quantitativas. As posições dos picos (deslocamento químico) são medidas em unidades de freqüência a partir de um pico de referência.

Os elétrons que envolvem o próton blindam o mesmo se o campo induzido se opõe ao campo externo. Pelo fato da blindagem ser dependente do ambiente químico, as intensidades de campo necessárias à absorção de energia por diferentes prótons são deslocadas quimicamente, em relação a algum padrão. Tetrametil-silano (TMS) é o padrão usual. O deslocamento químico de 
um certo núcleo de hidrogênio ou carbono é a diferença entre a intensidade de campo na qual o próton absorve e a intensidade do campo na qual os prótons do TMS absorvem.

Espectros de RMN de macromoléculas são usualmente diferentes dos espectros apresentados pelas moléculas de baixa massa molar de igual constituição química. Isto ocorre devido às características particulares das macromoléculas, tal como alta viscosidade e baixa mobilidade. Obviamente os sinais detectados são referentes às unidades repetitivas do polímero em questão. No entanto, quando há diferentes configurações da cadeia polimérica, aparecem no espectro do polímero outros picos referentes a um mesmo grupo ou unidade repetitiva, os quais não são equivalentes magneticamente. A estereorregularidade da cadeia polimérica é a principal responsável pelo surgimento destes picos. Dentre os núcleos paramagnéticos, com número quântico igual a n/2, os mais utilizados para o estudo de estruturas moleculares são ${ }^{1} \mathrm{H}$ e ${ }^{13} \mathrm{C}$.

Os espectros de RMN foram obtidos com um espectrômetro Varian (Unity 400), utilizando uma sonda de sólido da Doty. A freqüência de ressonância foi $100,58 \mathrm{MHz}\left({ }^{13} \mathrm{C}\right)$, banda espectral para a polarização cruzada e desacoplamento de $50-70 \mathrm{kHz}$, tempo de contato para polarização cruzada de $1 \mathrm{~ms}$ e tempo de repetição de 3 s. O pulso de ${ }^{1} \mathrm{H}$ foi de $4 \mu$ s, enquanto que os espectros foram obtidos com 1024 pontos e processados com 4096 pontos. Os deslocamentos químicos foram medidos em relação ao tetrametilsilano via hexametilbenzeno como referência secundária (pico aromático em 132,3 ppm). Nos experimentos foram acumulados 1000 transientes. As amostras foram solubilizadas em DMSO deuterado e foram medidas em rotores de zircônia de $5 \mathrm{~mm}$ de diâmetro, com freqüência de rotação em torno de $11 \mathrm{kHz}$ 


\subsection{2 - Espectroscopia na Região do Infravermelho}

A chamada radiação infravermelha (IR) corresponde à parte do espectro situada entre as regiões do visível e das microondas. A porção de maior utilidade para o químico orgânico está situada entre 4000 e $400 \mathrm{~cm}^{-1}$.

Embora o espectro de infravermelho seja característico da molécula como um todo, certos grupos de átomos dão origem a bandas que ocorrem mais ou menos na mesma freqüência, independentemente da estrutura da molécula. É justamente a presença destas bandas características de grupos que permite ao químico a obtenção, através de simples exame do espectro e consulta a tabelas, de informações estruturais úteis e é neste fato que nos baseamos para fazer a identificação de estruturas.

Absorção na região do Infravermelho (IR) é devida a movimentos vibracionais e rotacionais dos grupos moleculares e ligações químicas de uma molécula. Essencialmente, existem duas vibrações fundamentais: estiramento das ligações, quando os átomos permanecem no mesmo eixo da ligação, porém a distância entre os átomos aumenta ou diminui e deformação angular, quando as posições dos átomos mudam em relação ao eixo de ligação original. Se luz infravermelho de mesma freqüência de vibração, de estiramento ou de deformação angular, incide na amostra, a energia é absorvida e a amplitude de vibração é aumentada. Devido à energia de absorção na freqüência de ressonância, o detector do espectrômetro de infravermelho grava um pico de absorção naquele número de onda. Vibrações de deformação angular geralmente requerem energias menores e são encontradas em freqüências menores do que as vibrações de estiramento $^{1,2,3}$.

As análises espectroscópicas no infravermelho foram realizadas utilizando um espectrofotômetro Spectrum 1000 da Perkin-Elmer com transformada de Fourier. Equipamento 
este pertence ao Centro de Caracterização e Desenvolvimento de Materiais - CCDM UFSCar/UNESP. O espectro foi obtido com 24 repetições, leitura de 4000 a $400 \mathrm{~cm}^{-1}$, e resolução igual a $2 \mathrm{~cm}^{-1}$. As amostras foram prensadas na forma de pastilhas com $\mathrm{KBr}$ (grau espectroscópico) na proporção de 100:1 KBr/amostra. Tanto o $\mathrm{KBr}$ como as amostras foram previamente secas em estufa a vácuo a $60^{\circ} \mathrm{C}$ por $24 \mathrm{~h}$ e, depois, misturadas e trituradas. As amostras trituradas com $\mathrm{KBr}$ foram novamente secas em estufa a vácuo, a $60^{\circ} \mathrm{C}$, por $24 \mathrm{~h}$. Após esse período, as amostras com $\mathrm{KBr}$ foram prensadas e imediatamente colocadas no aparelho para análise.

\subsection{3 - Cromatografia de Permeação em Gel (GPC)}

A cromatografia de permeação em gel (GPC) é um dos métodos mais empregados de separação e análise de materiais poliméricos. Uma solução polimérica é injetada em colunas, preenchidas por partículas contendo poros de tamanhos definidos. O volume de solvente contido no interior dos poros corresponde ao volume da fase estacionária e o intersticial às partículas corresponde ao volume da fase móvel. Moléculas cujo tamanho é maior que o tamanho dos poros não conseguem se difundir nesses poros (fase estacionária), permanecendo na fase móvel. Por outro lado moléculas pequenas se difundem pela fase estacionária, necessitando assim de uma quantidade maior de solvente para alcançar a eluição da coluna. Desta forma as moléculas de maior massa molar tem um tempo de retenção na coluna inferior ao tempo de retenção de moléculas de massa molar menor.

Para efetuas estas análises fez-se uma curva de calibração utilizando 10 padrões de pullulan - American Polymer, na concentração de $3 \mathrm{mg} / 2 \mathrm{~mL}$ de eluente.

Utilizou-se um cromatógrafo com as seguintes características: 
COLUNAS: Pré-col. Ultrahydrogel ${ }^{\mathrm{TM}}+3$ colunas em série Ultrahydrogel $^{\mathrm{TM}}$ Linear (Waters). Ultrahydrogel $^{\mathrm{TM}}$ Linear : 7,8 mm DI x $300 \mathrm{~mm}$ comprimento (cada coluna).

Enchimento: gel de metacrilato entrecruzado - (gel inorgânico baseado em silica gel).

Limite de exclusão da coluna Ultrahydrogel ${ }^{\mathrm{TM}}$ Linear (PEO) : 500 - 5.000.000.

ELUENTE: solução 0,1N $\mathrm{NaNO}_{3} / \mathrm{PH}=11,5$.

FLUXO: $0,8 \mathrm{~mL} / \mathrm{min}$.

PRESSÃO: $22 \mathrm{Kgf} / \mathrm{cm}^{2}$.

DETECTOR (ch1): IR.

DETECTOR (ch2): UV/254nm.

TEMPERATURA: $35^{\circ} \mathrm{C}$

LOOP: 20uL.

Equipamento: Cromatógrafo Líquido HP-SEC . Marca: Shimadzu equipado com: Bomba (modelo LC-10AD); Controlador de Sistema (modelo SCL-10 A); Detector de Índice de Refração Diferencial (modelo RID 6 A); Detector Espectrofotométrico UV-Visível (modelo SPD-10AV); Forno para coluna (modelo CTO-10 A); Processador de dados - Cromatopac (modelo C-R7AE) e Injetor de amostras / 20 $\mu \mathrm{L}$ - Rheodyne (modelo 7125), dados tratados com GPC Software para CLASS-LC10.

As amostras foram preparadas do seguinte modo:

SOLUCÃO $1=450 \mathrm{mg}$ amostra amido $+15 \mathrm{~mL}$ de $\mathrm{NaOH} 1 \mathrm{M}$, sob agitação a temperatura ambiente por $2 \mathrm{~h}$.

Amido Nativo: $450 \mathrm{mg}$ amostra amido $+15 \mathrm{~mL}$ de $\mathrm{NaOH} 1 \mathrm{M}$, sob agitação a temperatura $65^{\circ} \mathrm{C}$ por $30 \mathrm{mim}$. 
SOLUÇÃO $2=2 \mathrm{~mL}$ da solução $1+4 \mathrm{~mL}$ de eluente . Esta solução 2 foi filtrada em membrana de fibra de vibro de porosidade 1,0 um e injetada no mesmo dia para analise . (volume de injeção $=20 \mathrm{uL}$ ).

\subsection{4 - Determinação do Grau de Substituição (DS) das amostras de amido modificados}

O Grau de Substituição (DS) das amostras de amidos modificados foi determinado por titulação: pesando-se $10 \mathrm{~g}$ do amido seco em um erlenmeyer, completou-se com $65 \mathrm{ml}$ de água destilada, e neutralizou-se adicionando-se algumas gostas de $\mathrm{NaOH}$ 0,01M, na presença de fenolftaleína, até uma coloração rósea ser mantida por 1 minuto.

Em seguida adicionou-se $25 \mathrm{ml}$ de $\mathrm{NaOH} 0,5 \mathrm{M}$, homogeneizou-se a mistura, a $25^{\circ} \mathrm{C}$, por 35 minutos. Titulou-se a mistura resultante com $\mathrm{HCl} 0,5 \mathrm{M}$.

O DS foi calculado de acordo com o método de Wurzburg 4:

$\mathrm{DS}=[(25-\mathrm{x}) * 0,043 * 0,5 * 100] / \mathrm{a}$

Onde: $25=$ volume de $\mathrm{NaOH}(0,5 \mathrm{M})$ adicionado na amostra, $\mathrm{x}=$ volume de $\mathrm{HCl}(0,5 \mathrm{M})$ usado na titulação da amostra, $0,043=$ constante $0,5=$ molaridade das soluções de $\mathrm{NaOH}$ e $\mathrm{HCl}$ utilizadas, $\mathrm{a}=$ massa de amostra de amido seco. 


\subsection{5 - Análise Elementar}

A análise elementar foi realizada em equipamento analítico e de combustão. Com essa técnica é possível determinar as porcentagens dos átomos de carbono, hidrogênio, nitrogênio e enxofre. O teor de oxigênio, de modo geral, não é obtido diretamente, como regra ele é determinado por diferença. Através das porcentagens atômicas pode-se calcular a fórmula mínima dos compostos.

As análises elementares foram feitas utilizando equipamento da marca CE (Carlo Erba) Instruments, modelo EA 1110 CHNS-O, utilizando-se os padrões de L-cistina $\left(\mathrm{C}_{6} \mathrm{H}_{12} \mathrm{~N}_{2} \mathrm{O}_{4} \mathrm{~S}_{2}\right)$, DL-metionina $\left(\mathrm{C}_{5} \mathrm{H}_{11} \mathrm{NO}_{2} \mathrm{~S}\right)$, sulfanilamida $\left(\mathrm{C}_{6} \mathrm{H}_{8} \mathrm{~N}_{2} \mathrm{O}_{2} \mathrm{~S}\right)$ e BBOT $\left(\mathrm{C}_{26} \mathrm{H}_{26} \mathrm{~N}_{2} \mathrm{O}_{2} \mathrm{~S}\right)$.

\section{2 - Preparação dos Filmes de Amido de Mandioca Modificados}

Para este trabalho utilizou-se amido de mandioca nativo e modificado (acetilado e oxidado acetilado). As amostras foram dispersas em água e aquecidas por 2 horas em uma temperatura de aproximadamente $100^{\circ} \mathrm{C}$, procedimento este para efetuar o rompimento dos grânulos do amido. Posteriormente, a dispersão foi resfriada a temperatura ambiente e adicionouse o plastificante (glicerol, sorbitol ou etileno glicol - Synth) em percentuais de 25,30 e $50 \%$ em relação à massa do amido.

Após, a adição do plastificante, a solução foi deixada por cerca de 1 hora sob agitação para uma melhor homogeneização. Em seguida, adicionou-se o sal, perclorato de lítio $\left(\mathrm{LiClO}_{4}\right)$ (Aldrich) em concentrações que variaram de 8 a 30 mols de oxigênios por mols de lítio ([O]/[Li]). O cálculo para obter a quantidade de mols de oxigênio, foi feito em relação aos oxigênios presentes na glicerina e no amido. A solução foi dispersa em uma placa de Teflon ${ }^{\circledR} \mathrm{e}$ 
seca durante 48 horas à $40^{\circ} \mathrm{C}$. Os filmes obtidos foram estocados em um dessecador e caracterizados por difração de raios-X, microscopia eletrônica de varredura (MEV), espectroscopia no ultravioleta-visível, espectroscopia de impedância eletroquímica (EIE) e análises térmicas (DSC e TGA).

\section{3 - Caracterização dos filmes obtidos}

\subsection{1 - Difração de raios- $X$}

A técnica de difração de raios-X é usada na investigação da estrutura fina do material. No princípio era usada para a determinação da estrutura cristalina. Com o desenvolvimento da técnica, hoje é usada para vários fins como análises químicas, medidas de tamanho de partículas e determinação de orientação de cristais. raios-X, irradiação eletromagnética de comprimento de onda entre 0,5 e 2,5 A, são produzidos quando elétrons com alta velocidade colidem com uma placa de metal liberando este tipo de radiação em todas as direções. A intensidade indicada no gráfico de intensidade versus ângulo de Bragg é a soma das intensidades relativas de todos os raios difratados na mesma direção.

A difração ocorre essencialmente, devido à existência de certas relações entre fase de duas ou mais ondas. A luz difratada pode ser definida como uma onda de luz composta de um largo número de raios espalhados mutuamente reforçando um ao outro. Difração é, portanto, um fenômeno de espalhamento da luz e não é algo envolvendo algum novo tipo de interação entre raios-X e átomos.

Dois fatos geométricos são dignos de serem relembrados, a fim de se obter uma maior compreensão deste fenômeno: 1) A luz incidente, normal ao plano refletido e a luz difratada são 
sempre coplanares. 2) O ângulo entre a luz difratada e a luz transmitida é sempre $2 \theta$ (ângulo de Bragg). Esse é o ângulo de difração, o que é usualmente medido experimentalmente ${ }^{5}$.

Difração como já foi mencionado é um fenômeno de espalhamento de luz, em que um grande número de átomos coopera. Estes átomos são arranjados periodicamente em uma rede cristalina, os raios espalhados pelos átomos possuem fases definidas entre eles, e essa relação de fase pode ser na maioria das vezes uma interferência destrutiva, ou seja, as fases se cancelam, o que acontece em várias direções. Entretanto, em poucas direções dos raios espalhados, ocorre uma interferência construtiva, as fases se somam, levando a formação da luz difratada.

Muitos plásticos são particularmente cristalinos. Essas substâncias poliméricas são compostas de moléculas longas, geralmente em um estado de grande desarranjo, entretanto, há algumas regiões organizadas chamadas de "cristalinas". Essas regiões, tipicamente muito pequenas e altamente distorcidas, produzem linhas de difração muito largas. Por comparação, da intensidade integrada destas linhas, com regiões de baixa intensidade, sem presença de picos, devido à presença de regiões amorfas, pode se estimado o chamado "grau de cristalinidade" do polímero.

Através de difração de raios-X, pode-se descobrir os tamanhos dos cristais. As condições mais recentes e as quais são mais comuns em fibras e papel, são estudadas por um ou mais métodos. Em fato, o alinhamento dos cristalitos em fibras naturais como algodão e seda, tem sido conhecido a longo tempo, assim é que deu origem ao termo "fibra têxtil".

Com o avanço no desenvolvimento de materiais biodegradáveis baseados em amido plastificado, aprofundou-se o estudo na formação de tipos de cristais e suas influências em algumas propriedades mecânicas. Desta forma, utilizou-se a técnica de difração de raios-X, a fim de se observar à formação destes cristais em função de algumas variáveis como umidade, teor de 
plastificante e outras. Na figura $3.1^{6}$, está apresentado o difratograma e a fórmula para o cálculo do grau de cristalinidade da amostra de amido semicristalino.

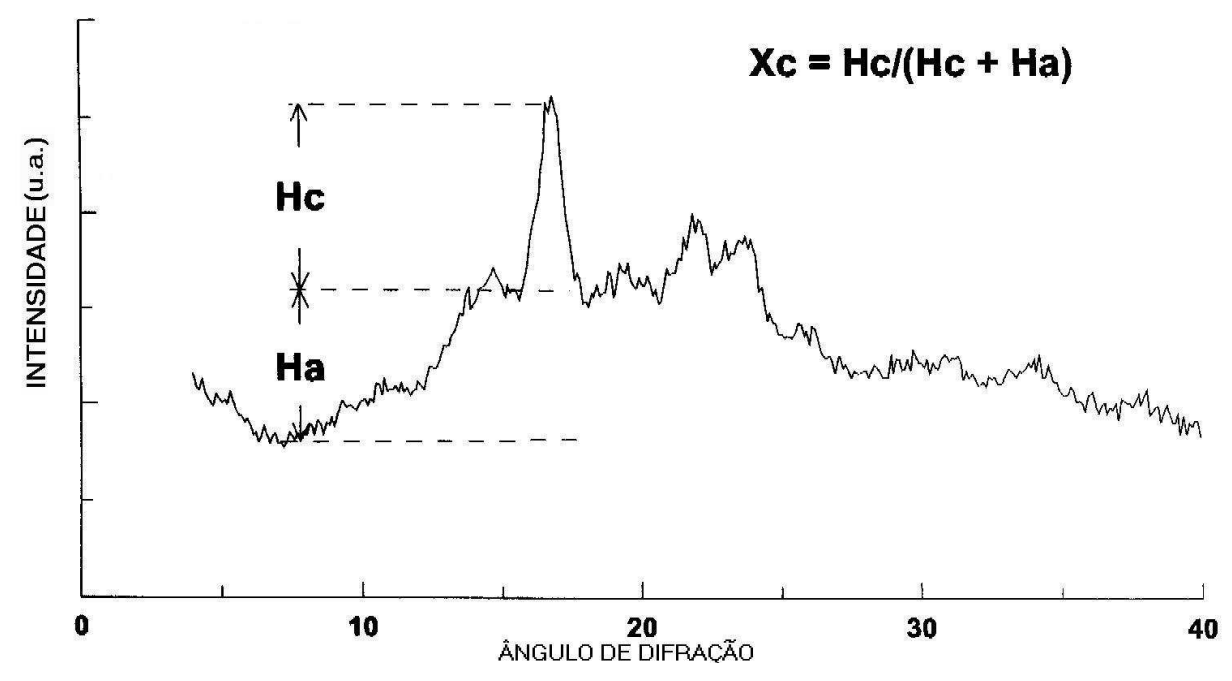

Figura 3.1 - Gráfico de difração de raios-X, obtido do amido, onde está demonstrado o cálculo para a determinação do grau de cristalinidade ${ }^{6}$.

Com relação aos eletrólitos sólidos poliméricos, a presença de regiões cristalinas é prejudicial à movimentação do íon. Portanto, utilizou-se a difração de raios-X para verificar se os filmes obtidos possuem ou não regiões cristalinas, e quando possível calcular o grau de cristalinidade do polímero.

As medidas foram feitas em um Difratômetro Universal de raios-X URD-6, CARL ZEISS JENA, a potência $\mu=40 \mathrm{KV} / 20 \mathrm{~mA}$ e $\lambda\left({ }_{\mathrm{CuK} \alpha}\right)=1540 \AA \hat{\text {. }}$. Medidas da intensidade de difração foram

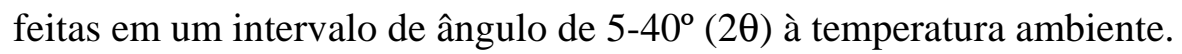




\subsection{2 - Microscopia Eletrônica de Varredura (MEV)}

As propriedades dos materiais podem ser também determinadas por suas respectivas microestruturas, isto é, pelos defeitos e constituintes microestruturais que eles contêm. Assim, no estudo de materiais, podem ser largamente utilizados três tipos de microscopia: microscopia óptica, microscopia eletrônica de varredura (MEV) e microscopia eletrônica de transmissão (MET). Menos freqüentemente, mas em faixa exclusiva de resolução, encontra aplicação a microscopia de campo iônico. Deve-se destacar que estas técnicas, na maioria dos casos, são complementares, sendo que cada uma delas tem seu campo específico de aplicação ${ }^{7}$.

A microscopia óptica permite a análise de grandes áreas, além de uso simples, rápido e pouco dispendioso.

A microscopia eletrônica de transmissão permite a análise de defeitos e fases internas dos materiais, como discordâncias, falhas de empilhamento e pequenas partículas de outra fase.

A microscopia de campo iônico, por apresentar excelente resolução, permite estudos difíceis de serem realizados com as outras técnicas, como defeitos puntiforme, "estrutura" de contornos e interfaces.

A técnica de microscopia eletrônica geralmente é utilizada para observações de amostras espessas, ou seja, basicamente não transparentes a elétrons. A principal razão de sua utilização está associada à alta resolução que pode ser atingida e à grande profundidade de foco, resultando imagens com aparência tridimensional.

O poder de resolução é muito grande comparado com o microscópio óptico, permitindo assim estudos altamente detalhados da morfologia superficial. Outra vantagem da MEV é a grande profundidade do foco. 
Além da capacidade da imagem provida pelos elétrons secundários produzidos quando os feixes de elétrons colidem na amostra, existem vários outros sinais providos pela interação do feixe de elétrons com o material.

O principal aspecto de formação da imagem do MEV, é um feixe altamente focado em um pequeno diâmetro $(5 \mathrm{~nm})$, que é seqüencialmente escaneado sobre a superfície da amostra em um campo regular de exploração sob o comando da bobina eletromagnética provida de um microscópico coluna.

Em um MEV, imagens são normalmente produzidas usando sinais obtidos dos elétrons secundários.

O MEV é considerado o mais potente modo para se produzir imagens de alta resolução e contraste. Também, porque pode operar a baixas voltagens de feixe e corrente do que outros modos, a amostra é provavelmente menos danificada, fazendo com que ela não sofra sérios danos, devido à irradiação. Assim, a imagem formada provida dos elétrons secundários, é um modo normalmente utilizado para a seleção inicial de uma área para observação. Entretanto, sob uma maior intensidade de irradiação, a amostra pode sofrer algum dano, como no caso de fibras

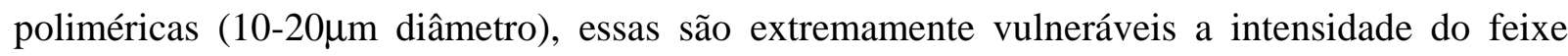
eletrônico. Até mesmo um pequeno aumento da temperatura promovida pela irradiação do feixe de elétrons, pode causar algumas modificações na amostra e na escala de observação. Com relação ao amido deve-se tomar o mesmo cuidado, pois uma exposição prolongada ao feixe eletrônico provocará alguns danos na amostra ${ }^{7}$.

Através do MEV, pode-se assim, observar a morfologia do polímero, sua orientação e as possíveis mudanças realizadas, como por exemplo, a plastificação e a dissolução do sal. 
A morfologia das amostras de amido com glicerol e perclorato de lítio foram analisadas em um microscópio eletrônico de varredura digital marca LEO modelo 440. Os filmes foram colocados sobre uma fita adesiva de carbono, no porta-amostra de alumínio e recobertas com ouro, com espessura de recobrimento de $20 \mathrm{~nm}$. A corrente do feixe utilizado foi de $1 \mathrm{pA}$ e a potência do feixe de $15 \mathrm{KV}$. Os filmes foram previamente secos em estufa à $40^{\circ} \mathrm{C}$ antes de serem fixados no porta-amostra.

\subsection{3 -Espectroscopia no ultravioleta-visível}

A absorção molecular na região do espectro ultravioleta e do visível depende da estrutura eletrônica da molécula. A absorção de energia é quantizada e conduz á passagem dos elétrons de orbitais do estado fundamental para orbitais de maior energia em um estado excitado. Para muitas estruturas eletrônicas, esta absorção ocorre em uma porção pouco acessível do ultravioleta ${ }^{2}$.

Um espectro de ultravioleta obtido diretamente de um instrumento nada mais é do que um gráfico de comprimento de onda (ou freqüência) versus a intensidade da absorção (absorbância ou transmitância) ${ }^{8}$. São usados dois parâmetros para caracterizar uma ligação: sua energia, dada pelo comprimento de onda $\lambda$ do máximo da absorção e sua intensidade de absorção.

A intensidade de luz cai exponencialmente quando passa através da amostra. Sua intensidade é medida usando a lei de Beer-Lambert para um certo comprimento de onda (equação $3.1)$;

$\mathrm{A}=\log _{10}\left(\mathrm{I}_{0} / \mathrm{I}\right)=\varepsilon \mathrm{dc}$ 
onde $\mathrm{A}$ é a absorbância, $\mathrm{I}_{0}$ é a radiação incidente na amostra, $\mathrm{I}$ é a radiação transmitida pela amostra, c é a concentração da amostra, d é o caminho ótico que a radiação percorre pela cela e $\varepsilon$ é o coeficiente de absorvidade molar ${ }^{8}$.

A energia total de uma molécula é a soma de suas energias eletrônica, vibracional e rotacional. A magnitude destas energias decresce na ordem: $\mathrm{E}_{\text {elet, }} \mathrm{E}_{\mathrm{vib}} \mathrm{e} \mathrm{E}_{\mathrm{rot}}$. A absorção de energia do ultravioleta produz modificações da energia eletrônica da molécula em consequiência de transições dos elétrons de valência. Estas transições implicam a excitação de um elétron de um orbital molecular ocupado ao primeiro de energia superior. As transições são caracterizadas por picos de absorção usualmente de caráter Gaussiano, pois além da transição eletrônica presente nestes espectros, também temos transições vibracionais e rotacionais, fazendo com que haja um alargamento dos picos $9,10,11$.

Dois tipos de elétrons contribuem para a absorção eletrônica, os que participam diretamente na formação da ligação entre os átomos, e os que não estão compartilhados, ou seja, elétrons livres, os quais estão localizados a cerca de tais átomos como: oxigênio, os halogênios, enxofre e nitrogênio ${ }^{10}$.

A técnica de espectroscopia de UV/vis opera em duas faixas de luz, no ultravioleta de 200 a $400 \mathrm{~nm}$, e no visível de 400 a $800 \mathrm{~nm}$.

A utilização da técnica de UV-vis para eletrólitos sólidos poliméricos está baseada, principalmente, na observação da transmitância deste material na região do visível (400 a 800 nm), devido a uma futura aplicação em janelas eletrocrômicas, desta forma, quanto maior a transmitância nesta região, maior será a transparência do filme. 
Os espectros foram obtidos de filmes de EPS na forma de filmes, de espessuras entre 0,17 e 0,32 mm, aderidos em uma placa de quartzo, empregando-se o espectrômetro da marca HITACHI, modelo U-3501.

\subsection{4 - Espectroscopia de Impedância Eletroquímica (EIE)}

A propriedade de condução dos eletrólitos sólidos poliméricos pode ser realizada determinando-se a condutividade iônica em função da temperatura e identificando-se a contribuição e a quantidade das diferentes espécies carregadas na condução. Para a medida da condutividade dos filmes obtidos utilizou-se da técnica de espectroscopia de impedância eletroquímica (EIE), sendo que a condutividade iônica total $(\sigma)$ foi calculada segundo a equação: $\sigma=1 /\left(\mathrm{R}^{*} \mathrm{~s}\right)$, onde 1 é a espessura do filme, s a área superficial e $\mathrm{R}$ a resistência.

O diagrama de impedância foi obtido através do impedancímetro Eco Chemie-Autolab PGSTAT 30, com módulo FRA2, acoplado a um micro-computador, num intervalo de frequiência de $10 \mathrm{~Hz}$ a $10^{6} \mathrm{~Hz}$ com amplitude de $5 \mathrm{mV}$. As medidas foram realizadas a vácuo, e a diferentes temperaturas (de ambiente até $80^{\circ} \mathrm{C}$ ), o aquecimento da célula foi realizado com o auxílio de um forno EDG \%P, equipado com um termopar alocado ao lado da amostra para permitir a leitura direta da temperatura do sistema.

O método da corrente alternada $(c a)$, EIE, é o mais popular para determinação das propriedades elétricas dos eletrólitos poliméricos. Isto ocorre devido, a utilização de uma simples célula incorporando um eletrodo inerte de bloqueio, em que pode ser usado para determinar propriedades eletrolíticas. Embora, comparando com a técnica da corrente contínua $(c c)$, o equipamento requerido e a teoria necessária para interpretar às medidas, são mais complexas. Existe outra razão para a popularidade da técnica $c a$. Os dados obtidos levam informações não 
somente sobre a migração de longo alcance dos íons, mas também sobre o fenômeno de polarização ocorrendo dentro da célula, por exemplo, a relaxação dos íons capturados. Através, do experimento em corrente alternada se define a impedância da célula ${ }^{12}$.

Em um experimento ca um potencial senoidal é aplicado para uma célula e a corrente senoidal, passada através da célula é determinada, como um resultado desta perturbação (Figura $3.2)$.

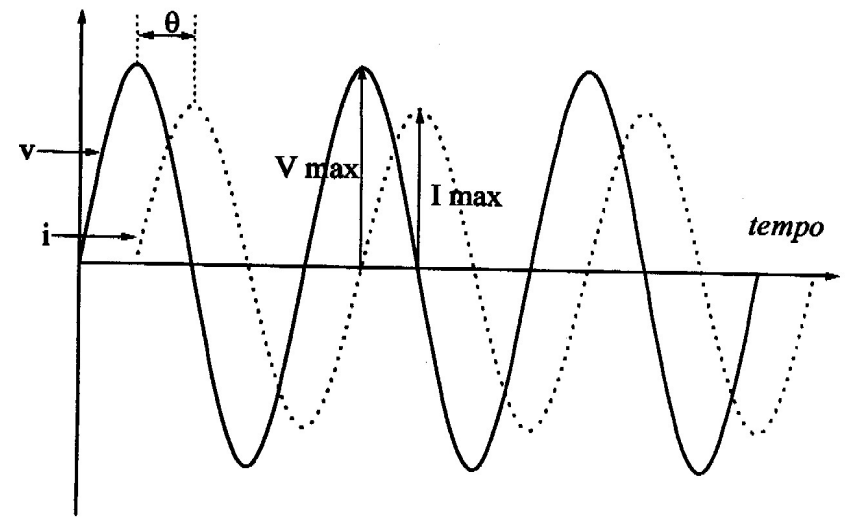

Figura 3.2 - Representação da voltagem e corrente senoidais, a uma dada freqüência, associada a uma célula eletroquímica; $\mathrm{V}=$ voltagem, $\mathrm{I}=$ corrente, $\theta=$ ângulo de fase entre voltagem $\mathrm{e}$ corrente.

Para medidas em $c c$, aplica-se uma corrente (I), relata-se um potencial (V), e como único parâmetro, a resistência R, onde $\mathrm{R}=\mathrm{V} / \mathrm{I}$. Entretanto, no caso de uma perturbação $c a$, dois parâmetros são requeridos para relacionar a corrente circulante pelo potencial aplicado. Um representa a oposição pelo fluxo de carga e é igual para a relação da voltagem e corrente máxima, $\mathrm{V}_{\text {máx }} / \mathrm{I}_{\text {máx }}$, sendo análogo para a resistência em medidas $c c$. O outro parâmetro $\theta$, é a diferença de fase entre a voltagem e a corrente. A combinação desses parâmetros representa a impedância $(Z)$ 
da célula. Tanto a impedância $[\mathrm{Z}]=\mathrm{V}_{\text {máx }} / \mathrm{I}_{\text {máx }}$, como o ângulo de fase $\theta$, são funções de freqüência aplicada. O método que é do nosso interesse envolve medidas de impedância em função da frequiência aplicada, assim pode-se extrair informações sobre diferentes propriedades elétricas da célula.

A impedância é um vetor quantidade, envolvendo magnitude e a fase, onde cada ponto pode ser representado em um diagrama vetorial. A representação da impedância neste diagrama é análoga a representação do número complexo em um plano complexo. Assim a impedância, pode convenientemente ser representada por um número complexo. Por esta razão ela é freqüentemente chamada de impedância complexa, sendo representada pelo símbolo $Z^{* 13}$.

Um típico experimento $c a$, consiste em determinar a impedância complexa da célula em função do sinal de freqüência e apresentar os resultados em forma do gráfico de impedância complexa como mostrado na Figura 3.3. A representação gráfica da variação de Z” em função de Z é um semicírculo centrado sobre o eixo real. A resistência ôhmica do material (R) é dada pela intersecção da curva neste eixo (Figura 3.4) . A condutividade iônica total $(\sigma)$ é então calculada segundo a equação $3.2^{12}$.

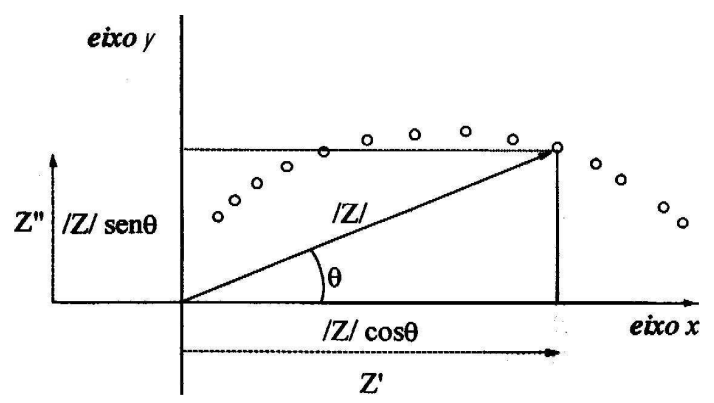

Figura 3.3 - Representação da impedância, Z, de uma celúla eletroquímica no diagrama vetorial, Z' e Z" são respectivamente as correspondentes real e imaginária da impedância complexa Z* =

$$
Z^{\prime}-\mathrm{j} \mathrm{P}^{\prime 14} \text {. }
$$


$\sigma=l /(R \cdot s)$

onde $l$ é a espessura do filme e s a área superficial.

Na Figura 3.4, está representado um semicírculo com raio d, o qual geralmente é obtido quando se gráfica a impedância imaginária pela real como mostrado na Figura 3.3.

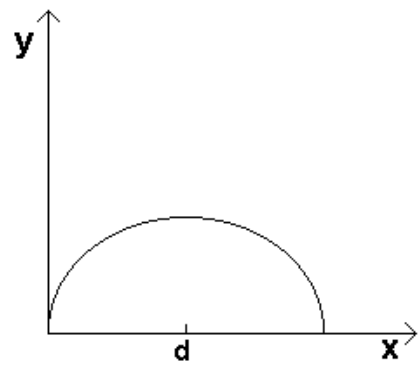

Figura 3.4- Representação de um semicírculo com raio d.

Ao utilizarmos a equação matemática que descreve este semicírculo tem-se que:

\section{Equação do círculo:}

$\mathrm{y}^{2}+(\mathrm{x}-\mathrm{d})=\mathrm{d}^{2}$

$y^{2}+x^{2}-2 d x+d^{2}-d^{2}=0$

$y^{2}+x^{2}-2 d x=0$

$y^{2}+x^{2}=2 d x$

Para eletrólitos sólidos poliméricos nos cálculos da resistência do material é usado geralmente um circuito RC//, representado na Figura 3.5. 


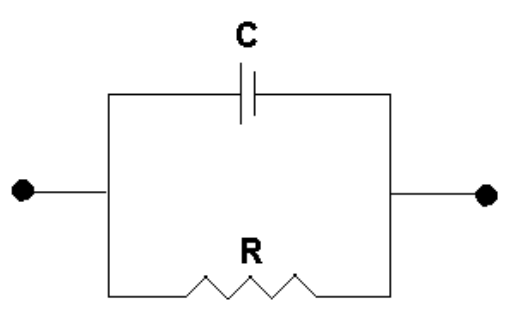

Figura 3.5 - Representação de um circuito $\mathrm{RC} / /^{\mathbf{1 4}}$.

A fim de demonstrar que o cálculo da resistência pela extrapolação no eixo x, está de acordo com a equação obtida do semicírculo e relacionada com um circuito RC//, tem-se que: $Z=\frac{R}{1+\omega^{2} C^{2} R^{2}}-\frac{j \omega C R^{2}}{1+\omega^{2} C^{2} R^{2}} \quad$ Equação para circuito $\mathrm{RC} / /$. (3.4)
parte real parte imaginária A $\quad$ B

$\begin{array}{llc}1 \mathrm{~A}\left(1+\mathrm{R}^{2} \mathrm{C}^{2} \omega^{2}\right)=\mathrm{R} & \mathbf{2} & \mathrm{B}\left(1+\mathrm{R}^{2} \mathrm{C}^{2} \omega^{2}\right)=-\mathrm{R}^{2} \mathrm{C} \omega \\ \omega^{2}=\frac{R-A}{A R^{2} C^{2}} & & \text { Substituindo } \omega^{2} \mathrm{em} 2 \text { tem-se que: }\end{array}$

$\frac{B}{A}=-\sqrt{\frac{R-A}{A}} \quad \rightarrow \quad \mathbf{B}^{2}+\mathbf{A}^{2}=\mathbf{A R}$

Comparando com a equação do círculo $\mathbf{y}^{2}+\mathbf{x}^{2}=\mathbf{2 d x}$, tem-se que: $\mathrm{R}=2 \mathrm{~d}$

Confirmando assim, que a intersecção do semi-círculo no eixo x é realmente referente a resistência do material. 
Desta forma realizou-se o cálculo de resistência utilizando este modelo, em que se pode observar na Figura 3.6, a qual representa o plano complexo de Nyquist. O aparecimento do semicírculo em altas freqüências é referente à parte resistiva da amostra e uma reta em baixas freqüências é atribuída à parte capacitiva. Este comportamento é comumente observado em eletrólitos sólidos poliméricos ${ }^{15,16}$. Observa-se que a impedância de um resistor não possui componente imaginária (Tabela 3.1), no entanto a impedância de um capacitor não tem componente real. Seu componente imaginário é uma função da capacitância e freqüência (Tabela 3.1). Assim, a impedância do capacitor varia inversamente com a frequiência, logo em altas freqüências a ela tende a zero. Entretanto, em baixas freqüências (aproximando da corrente dc) a sua impedância tende ao infinito. Portanto é por isso que as extrapolações para a determinação da resistência do eletrólito acontecem geralmente em altas a médias freqüências, pois assim diminui a contribuição da parte capacitiva.

Tabela 3.1 - Equação de impedância para elementos do circuito equivalente ${ }^{14}$

\begin{tabular}{|l|l|}
\hline Elemento de Circuito & Equação de Impedância \\
\hline & $z=R+0 j=R \quad j=\sqrt{-1}$ \\
\hline$\bullet$ & $z=0-\frac{j}{\omega C} \quad \omega=2 \pi f$ \\
\hline$\bullet$ & $Z=0$ \\
\hline
\end{tabular}


Como relatado, para efetuar o cálculo da resistência do eletrólito basta extrapolar as duas partes do semicírculo até o eixo x. Esta extrapolação é feita utilizando um ajuste pelo aparelho Eco Chemie-Autolab PGSTAT 30 com modulo FRA2 (Figura 3.10). Este ajuste é equivalente a circuito RC// (Tabela 3.1), ou seja, capacitância e resistência em paralelo, o qual é representado na Figura 3.5. A resposta deste ajuste esta demonstrada na Figura 3.7.

O termo $\frac{R}{1+\omega^{2} C^{2} R^{2}}$ é referente a parte real da impedância para o circuito RC// (Tabela 3.1), logo quando se faz a extrapolação da curva no eixo x, a parte imaginária tende a zero, então o valor da resistência da amostra é obtido da parte real. Obtendo o valor da resistência da amostra é possível calcular a condutividade iônica da mesma, através da equação 3.2 .

Para a amostra em questão (Figura 3.6), o ajuste do semicírculo (Figura 3.7) forneceu um valor de resistência igual:

\section{$\mathrm{R}=1,72 \times 10^{3} \Omega$}

tendo, a área da amostra $\mathrm{s}=\mathbf{1 , 7 7} \mathbf{c m}^{2}$;

e a espessura $\mathbf{l}=\mathbf{0 , 0 2 5} \mathbf{c m}$

o valor da condutividade iônica utilizando a equação 3.2 é:

$\sigma=8,21 \times 10^{-6} \Omega^{-1} \mathrm{~cm}^{-1}$, ou $8,21 \times 10^{-6} \mathrm{~S} \mathrm{~cm}^{-1}$. 


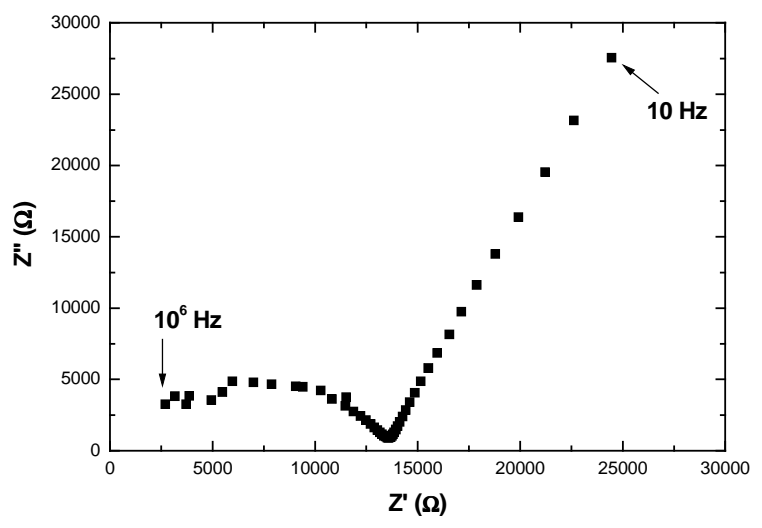

Figura 3.6 - Plano complexo de Nyquist para filme de amido oxidado-acetilado com $30 \%$ de glicerol e $30[\mathrm{O}] /[\mathrm{Li}]$ na temperatura de $30^{\circ} \mathrm{C}$.

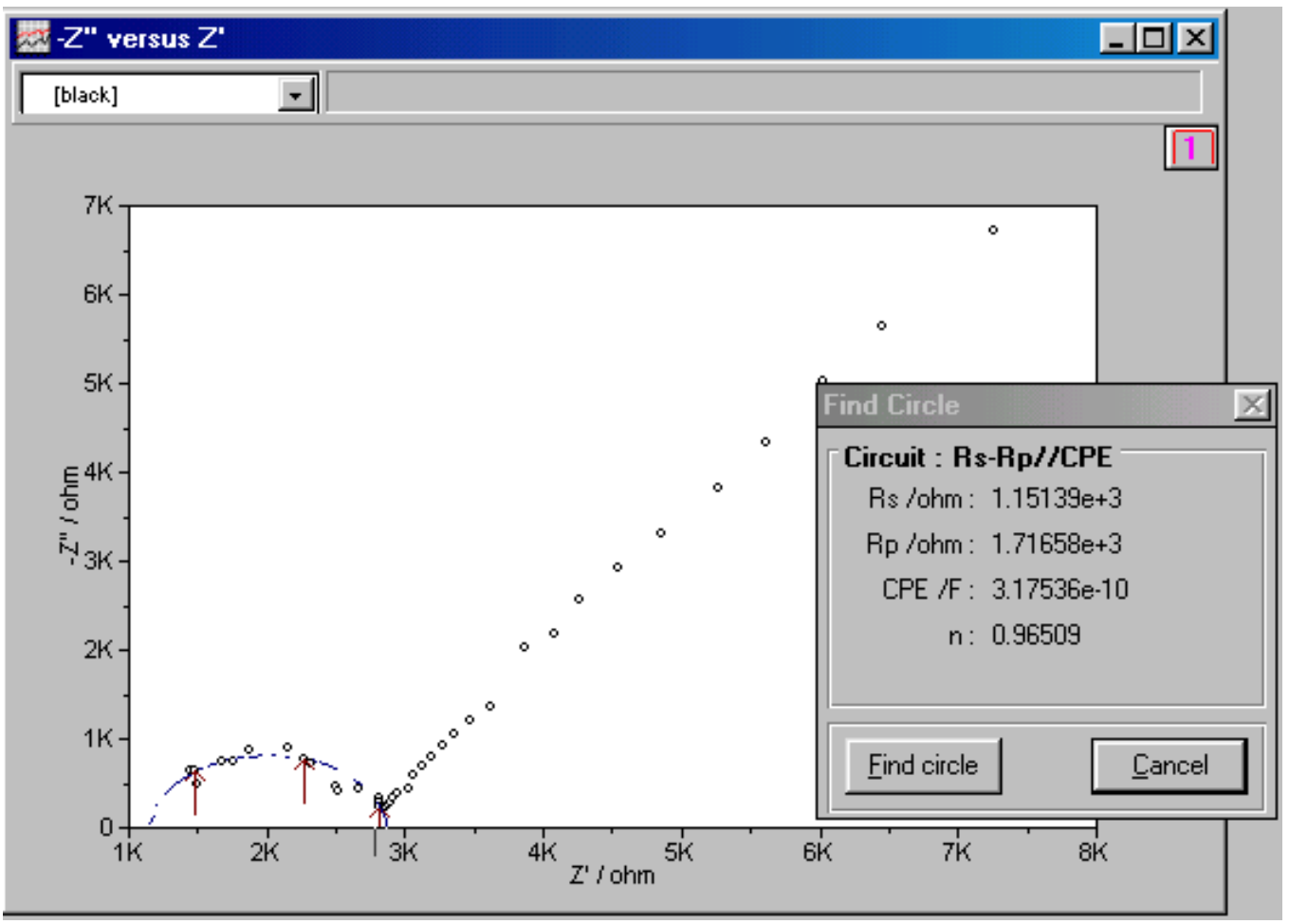

Figura 3.7 - Ajuste da curva do plano complexo de Nyquist para filme de amido oxidadoacetilado com $30 \%$ de glicerol e $30[\mathrm{O}] /[\mathrm{Li}]$ na temperatura de $30^{\circ} \mathrm{C}$. 
O aumento da temperatura provoca uma mudança significativa no espectro de impedância como pode ser observado na Figura 3.8. Nota-se que ocorre o desaparecimento do semicírculo referente a parte resistiva, desta forma o cálculo da resistência é feito pela extrapolação da parte capacitiva no eixo x como apresentado na Figura $3.8^{15}$.

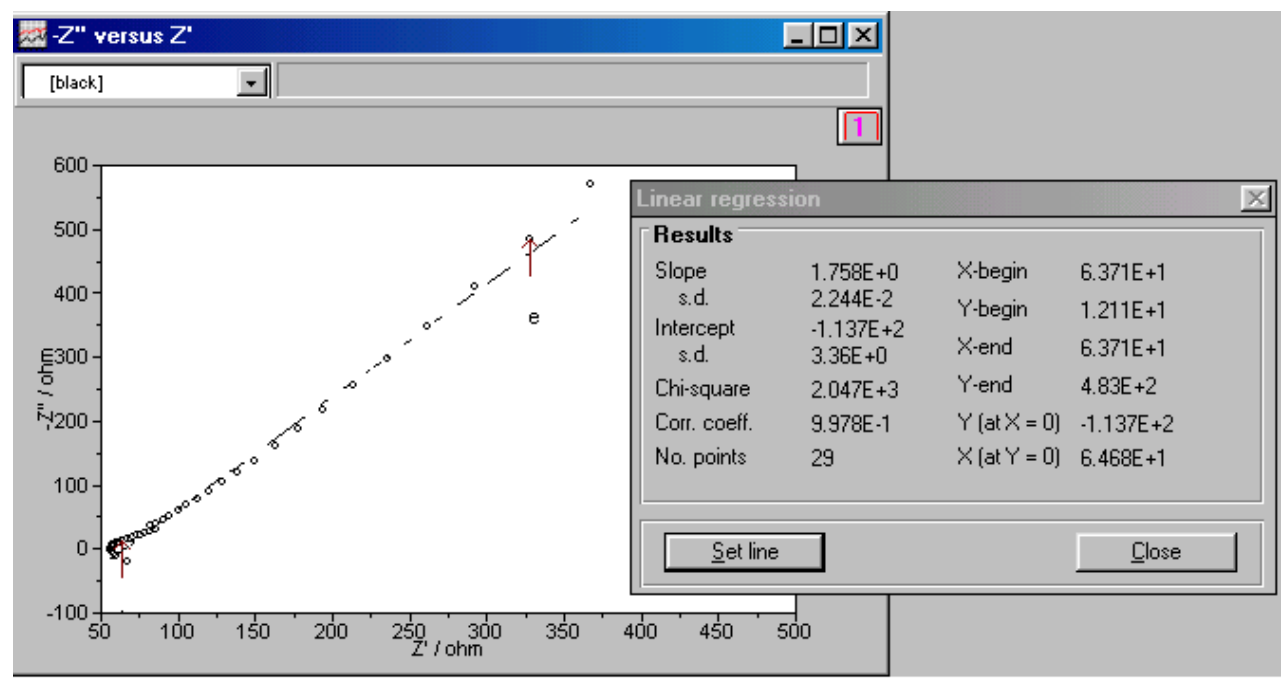

Figura 3.8 - Ajuste da curva do plano complexo de Nyquist para filme de amido oxidado e acetilado com $30 \%$ de glicerol e $30[\mathrm{O}] /[\mathrm{Li}]$ na temperatura de $80^{\circ} \mathrm{C}$.

O cálculo da condutividade iônica para este caso é semelhante ao demonstrado anteriormente, onde para esta amostra a $80^{\circ} \mathrm{C}$, a resistência é igual a:

$$
\mathrm{R}=6,47 \times 10^{1} \Omega
$$

tendo, a área da amostra $\mathbf{s}=\mathbf{1 , 7 7} \mathbf{c m}^{\mathbf{2}}$;

e a espessura $\mathbf{l}=\mathbf{0 , 0 2 5} \mathbf{~ c m}$

o valor da condutividade iônica utilizando a equação 3.2 é:

$\sigma=2,20 \times 10^{-4} \Omega^{-1} \mathrm{~cm}^{-1}$, ou $2,43 \times 10^{-4} \mathrm{~S} \mathrm{~cm}^{-1}$. 
O sistema utilizado para a determinação da condutividade está representado na Figura 3.9. As amostras de superfície e espessura variável são prensadas entre dois eletrodos de aço (6) inoxidável polidos e contidos numa guia de porta-amostras de Teflon ${ }^{\circledR}$ (7). Este é colocado ao fundo de uma célula de medida. Os contatos elétricos são o fundo metálico da célula (Kovar) (8) e a haste de aço inoxidável (1) posicionada sobre o eletrodo superior. A célula foi concebida de tal forma a permitir a prensagem da amostra sob vácuo (3).

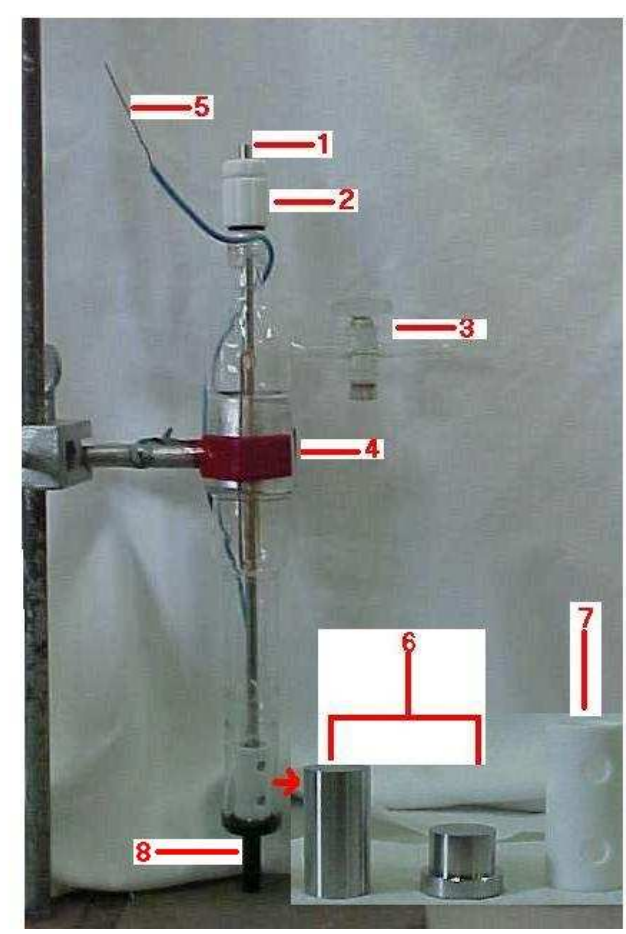

Figura 3.9 - Célula de medida utilizada nos experimentos de determinação de condutividade dos filmes: (1) contato do eletrodo superior (haste de inox ); (2) tampa de Teflon ${ }^{\circledR} \operatorname{com}$ rosca; (3) torneira para conectar a bomba de vácuo; (4) junta em vidro; (5) fio de cobre para estabelecer o contato com o metal; (6) eletrodo inferior e superior; (7) guia do porta amostra (Teflon $®)$ e (8) metal que estabelece o contato com o eletrodo inferior (Kovar). 
Como mostra a Figura 3.10, um termopar (4) colocado dentro da haste, o qual fica próximo da amostra, permite a leitura direta da temperatura do sistema. O aquecimento da célula (da temperatura ambiente até $80^{\circ} \mathrm{C}$ ) é realizado com o auxílio de um forno EDG1800 (2). O diagrama de impedância é obtido em um potenciostato Eco Chemie-Autolab PGSTAT 30 com modulo FRA2 (1). A frequiência utilizada foi de $10^{6}$ a $10 \mathrm{~Hz}$ com uma amplitude de $5 \mathrm{mV}$, acoplado a um microcomputador. As medidas foram realizadas sob vácuo, para evitar a influência da umidade, e voltagem constante de 0,1V. A Figura 3.11 apresenta uma visão interna do forno, com o sistema acoplado.

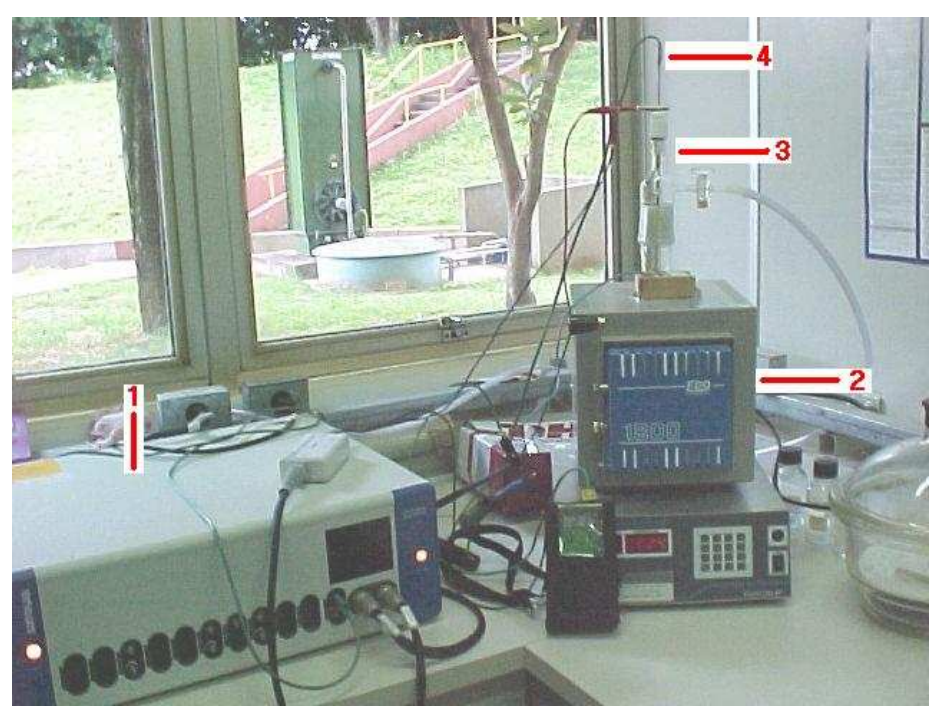

Figura 3.10 - Sistema utilizado para a realização das medidas de condutividade dos filmes: (1) potenciostato; (2) forno EDG; (3) célula de condutividade; (4) termopar. 


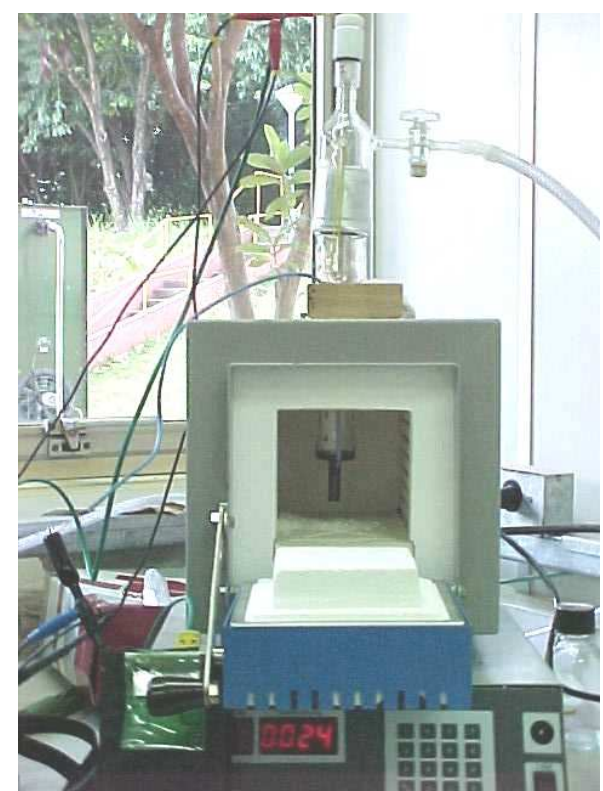

Figura 3.11 - Visão interna do forno.

\subsection{5 - Análises Térmicas (DSC e TGA)}

A DSC permite determinar as temperaturas nas quais ocorrem as transformações de fases das substâncias por meio da perda e ganho de calor das amostras. A análise de DSC pode ser feita em diferentes atmosferas (inerte, oxidante ou redutora). Esta análise mede o fluxo de calor em função da varredura da temperatura. O procedimento experimental consiste em colocar uma quantidade de amostra em um minicadinho de alumínio e, em seguida, aquecê-lo. A amostra e o material de referência são igualmente submetidos a uma temperatura programada e rigorosamente controlada. Ao longo da análise, a temperatura da amostra é comparada à temperatura do material de referência que é um material termicamente inerte. A temperatura de ambos é igual até que ocorram algumas modificações térmicas, como por exemplo, fusão, cristalização etc. do material. Ao ocorrer alteração na amostra, ocorrerá, também, adição ou subtração de energia térmica, da 
amostra para a referência, para mantê-las à mesma temperatura. Se a temperatura da amostra for menor que a de referência, temos processo endotérmico. Caso contrário, o processo é exotérmico. A quantidade de energia envolvida no processo equivale à quantidade de energia absorvida ou libertada na transformação ocorrida. Seu registro fornece medida calorimétrica direta da energia de transição ${ }^{17,18}$.

Na técnica de DSC (Figura 3.12) a transição é identificada quando a curva começa a desviar-se da linha de base (linha horizontal do gráfico). Uma vez completada a transição, a difusão térmica reconduz a amostra ao equilíbrio. O máximo (ou mínimo) da curva pode representar a temperatura para a qual se completa a transição. Se a inflexão não for nítida pode obter-se um ponto reprodutível traçando uma reta tangente à linha de base e outra tangente ao ramo inclinado inicial da curva.

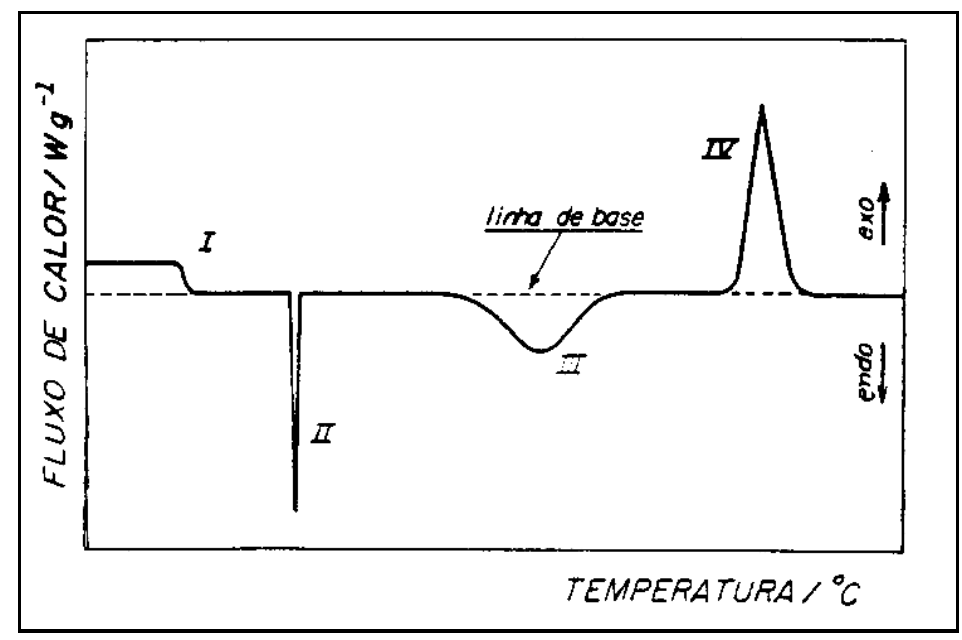

Figura 3.12- Curva representativa de DSC ${ }^{19}$.

Na Figura 3.12 estão ilustradas quatro tipos de transições: 
(I) Transição de segunda ordem, caracterizada por mudança na linha de base horizontal (por exemplo, transição vítrea em polímeros).

(II) Pico endotérmico agudo (característico de fusão, ebulição, redução etc).

(III) Pico endotérmico largo (reação de decomposição ou dissociação).

(IV) Pico exotérmico (por exemplo - oxidação).

Durante o processamento e no uso de materiais poliméricos, é de grande importância o conhecimento da temperatura de transição vítrea dos polímeros. Os plásticos são usados no estado sólido e, com, aumento da temperatura acima de sua temperatura de transição vítrea, tornam-se macios e se deformam. Por isso, sua transição vítrea marca a temperatura limite superior de uso, ou seja, sua resistência ao calor. Para as borrachas, a transição vítrea determina o limite inferior de uso, ou seja, a temperatura abaixo da qual ela se torna vítrea e é inútil para o uso.

Polímeros amorfos exibem mudança do comportamento vítreo abaixo da temperatura de transição vítrea para comportamento flexível borrachoso acima dessa temperatura ${ }^{19}$.

A transição vítrea se refere ao intervalo de temperatura em que o material polimérico muda de estado rígido (mais ordenado) para estado mais flexível (menos ordenado). Abaixo desta transição há relativamente pouca movimentação molecular e os segmentos da cadeia estão como que "congelados", sendo capazes de vibrar nestas posições fixas, mas com poucas chances de rearranjos nas posições. $\mathrm{O}$ aumento da temperatura torna maior a amplitude das vibrações e é possível a movimentação ocasional de segmentos da cadeia. Quanto mais flexível à cadeia, mais baixa a temperatura na qual isso irá ocorrer. Nesse intervalo de transição, todas as propriedades de um polímero amorfo, que dependam de movimento molecular, irão mostrar marcante 
alteração. Portanto, propriedades como viscosidade, calor específico, coeficiente de expansão, capacidade e módulo de elasticidade podem ser utilizadas para se determinar à transição vítrea.

Os aspectos fenomenológicos da transição vítrea estão associados à natureza amorfa dos polímeros, devido aos mecanismos que ocorrem nas regiões amorfas, enquanto as regiões cristalinas permanecem relativamente intactas. Quanto maior o grau de cristalinidade, menor o efeito da transição vítrea nas propriedades do material ${ }^{20}$.

As análises de DSC foram realizadas utilizando um detector tipo SHIMADZU DSC-50, porta amostra de alumínio tampada, atmosfera dinâmica de nitrogênio com um fluxo de 20 $\mathrm{mL} / \mathrm{min}$.

Fez-se uma corrida até $120^{\circ} \mathrm{C}$ a fim de ambientar termicamente a amostra e eliminar solvente se ainda presente, com uma taxa de aquecimento de $20^{\circ} \mathrm{C} / \mathrm{min}$, diferentemente, da segunda e da terceira corrida, as quais foram realizadas com $10^{\circ} \mathrm{C} / \mathrm{min}$, variando a temperatura de $-100^{\circ} \mathrm{C}$ até $140^{\circ} \mathrm{C}$, a fim de se obter a temperatura de transição vítrea das amostras, o que é de grande importância para a caracterização dos eletrólito sólidos poliméricos.

\section{Análise Termogravimétrica (TGA)}

A termogravimetria acompanha a variação da propriedade física, massa permitindo observar a perda de massa da amostra em função da temperatura. A obtenção dos resultados é vinculada aos produtos de decomposição térmica voláteis, ou pela incorporação de átomos ou moléculas, provenientes dos gases da atmosfera do forno que, respectivamente, diminuem ou aumentam a massa original da amostra. A aplicação da TGA em um problema particular é possível se for observada mudança de massa sobre a aplicação de calor. Se nenhuma mudança de massa for observada, podem ser empregadas outras técnicas térmicas como DTA, DSC, TMA etc. $^{19,20,21}$. 
A TGA registra a história térmica da amostra fornecendo informações sobre sua perda de massa relacionada aos fenômenos, tais como desorção, absorção, sublimação e decomposição como evidenciado na Tabela 3.2. As transições como fusão, cristalização e transição vítrea não apresentam mudanças de massa da amostra e, portanto não são detectados por esta técnica.

Tabela 3.2 - Mudanças de massa detectáveis por técnicas de TGA

\begin{tabular}{|l|l|}
\hline \multicolumn{2}{|c|}{ Análise Termogravimétrica } \\
\hline Mudanças físicas & Mudanças químicas \\
\hline Sublimação & Sólido $\rightarrow$ gás \\
\hline Vaporização & Sólido a $\rightarrow$ sólido b + gás \\
\hline Absorção e adsorção & Gás + sólido a $\rightarrow$ sólido b \\
\hline Desorção & Sólido a + sólido b $\rightarrow$ sólido c + gás \\
\hline
\end{tabular}

As curvas termogravimétricas são características de dado composto ou sistema, devido ao caráter específico da seqüência das reações físico-químicas que ocorrem ao longo de um intervalo definido de temperaturas; as velocidades são função da estrutura molecular. Variações na massa resultam da ruptura e/ou formação de diferentes ligações física e químicas, a elevadas temperaturas, as quais conduzem à liberação de produtos voláteis ou à formação de produtos de reação mais pesados. A partir dessas curvas, podem ser obtidos dados respeitantes à termodinâmica e cinética das diversas reações químicas, mecanismos de reação e produtos de reação, finais e intermediários.

As análises termogravimétricas foram feitas em equipamento da marca SHIMADZU modelo TGA-50, nas seguintes condições: 
Massa de amostra: $\cong 3 \mathrm{mg}$

Atmosfera: $\mathrm{N}_{2}$

Fluxo: $50 \mathrm{~mL} / \mathrm{min}$

Faixa de temperatura: ambiente até $800^{\circ} \mathrm{C}$

Razão de aquecimento: $10^{\circ} \mathrm{C} / \mathrm{min}$ 


\section{Referências Bibliográficas}

1 DYER, J.R. Aplicações da espectroscopia de absorção aos compostos orgânicos. São Paulo: Edgard Blücher Ltda, 1969. 151p.

2 SILVERSTEIN, R. M.; BASSLER, G. C. Spectrometric identification of organic compounds. 5.ed. New York: John Wiley, 1974. v.1

3 BELLAMY, L. J. The infra-red spectra of complex molecules. London: Chapman and Hall,. 1975. 433p

4 WURZBURG, O. B. Starch derivates and modification. In: Whisler, L. (Ed.). Methods in Carbohydrate Chemistry IV. New York: Acad. Press, 1964. p. 286-288.

5 CULLITY, B. D. Elements of X-ray diffraction. Reading, Addison-Wesley, 1978. 555p.

6 HULLEMAN, S.H.D.; KALISVAART, M.G.; JANSSEN, F.H.P.; FEIL, H.;

VLIEGENTHART, J.F.G. Origins of B-type crystallinity in glycerol-plasticised, compressionmoulded potato starches. Carbohydrate Polymers, v. 39, n. 4, p. 351-360, 1999.

7 WHITE, J. R.; THOMAS, E.L. Advances in SEM of Polymers. Rubber Chemistry and Technology, v. 57, p. 458-502, 1984.

8 SKOOG, D. A. Principles of Instrumental Analysis. 3. ed. Philadelphia, Saunders, 1985. $407 \mathrm{p}$.

9 SKOOG, D.A.; WEST, D.; HOLLER, F.J. Analytical Chemistry. Philadelphia, Saunders, 1990. 642p.

10 DENNEY, R. C.; SINCLAIR, R. Visible and ultraviolet spectroscopy. London, John Wiley, 1993. 197p. 
11 SOMMER, L. Analytical absorption spectrophotometry in the visible and ultraviolet the principles. New York: Elsevier, 1989.310p.

12 BRUCE, P. G. Electrical measurements on polymer electrolytes. In: Polymer electrolytes reviews. London: Elsevier, 1987. 237-274 p.

13 GIROTTO, E. M.; DE PAOLI, M. A. Mass transport in intrinsically conducting polymers: Importance, techniques and theoretical models. Química Nova, v. 22, n. 3, p. 358-368, 1999.

14 EG\&G PRINCETON APPLIED RESEARCH. Basics of electrochemical impedance spectroscopy (EIS). London: EG\&G Princeton Applied Research, 2000. 13p. (Apostila Application note AC-1).

15 MACDONALD, J. R. Impedance Spectroscopy. New York: Wiley, 1987. 346p.

16 GRAY, M.F. Solid Polymer Electrolytes. New York: VCH, 1991. 245p.

17 DANIELS, T. Thermal analysis. New York: John Wiley, 1973. 272p.

18 WENDLANDT, W.W. Thermal Analysis. New York: John Willey, 1986. v.19.

19 SIMAL, A L. Estrutura e propriedades dos polímeros. São Carlos: DEMa, 1992. 106p.

20 CAVALHEIRO, E.T.G. A Influência de Fatores Experimentais nos Resultados de Análises Termogravimétricas. Química Nova, v. 18, n. 3, p. 305-308, 1995.

21 HATAKEYAMA, T.; QUINN, F. X. Thermal Analysis: fundamental and applications to polymer science. New York: John Wiley, 1994. 158p. 


\section{Capítulo 4 - Resultados e Discussões}

\section{1 - Caracterização das amostras de amido}

Os eletrólitos sólidos poliméricos (ESPs) foram obtidos utilizando o amido de mandioca nativo e modificado, sendo: amido acetilado e amido oxidado-acetilado. Estas amostras foram gentilmente cedidas pela empresa Avebe do Brasil, entretanto sem as suas respectivas especificações, por isso propôs-se a estrutura do amido acetilado e do amido oxidado-acetilado, baseando-se na literatura $^{1}$ e utilizando as técnicas de caracterização por espectroscopia no infravermelho, RMN e análise elementar. Também foi estudada a distribuição de massa molecular das amostras de amido nativo e dos amidos modificados, através da técnica de cromatografia de permeação em gel (GPC).

\subsection{1 - Espectroscopia de RMN}

Os amidos de mandioca são bastante utilizados para produção de amidos modificados. As modificações do amido nativo são feitas para proporcionar produtos amiláceos com as propriedades necessárias para usos específicos, tais como espessamento, gelificação, adesão e/ou 
formação de filme. Os amidos oxidados produzem géis mais claros e de baixa viscosidade a quente quando comparados com o amido nativo. Por isso são usados em confecções de doces de goma mais claros e mais suaves. Os amidos acetilados apresentam redução na tendência ao processo de retrogradação.

Como citado anteriormente os amidos empregados neste trabalho são obtidos por modificações simples: oxidação - através de reação com hipoclorito de sódio e acetilação através de reação com anidrido acético. O fabricante não fornece especificações do produto, pois o controle da produção é feito baseado na medida de viscosidade do produto obtido. Deste modo, as análises dos espectros obtidos por RMN foram feitas levando em consideração a estrutura química destes amidos, cujas representações se encontram nas Figuras 4.1, 4.2 e 4.3.

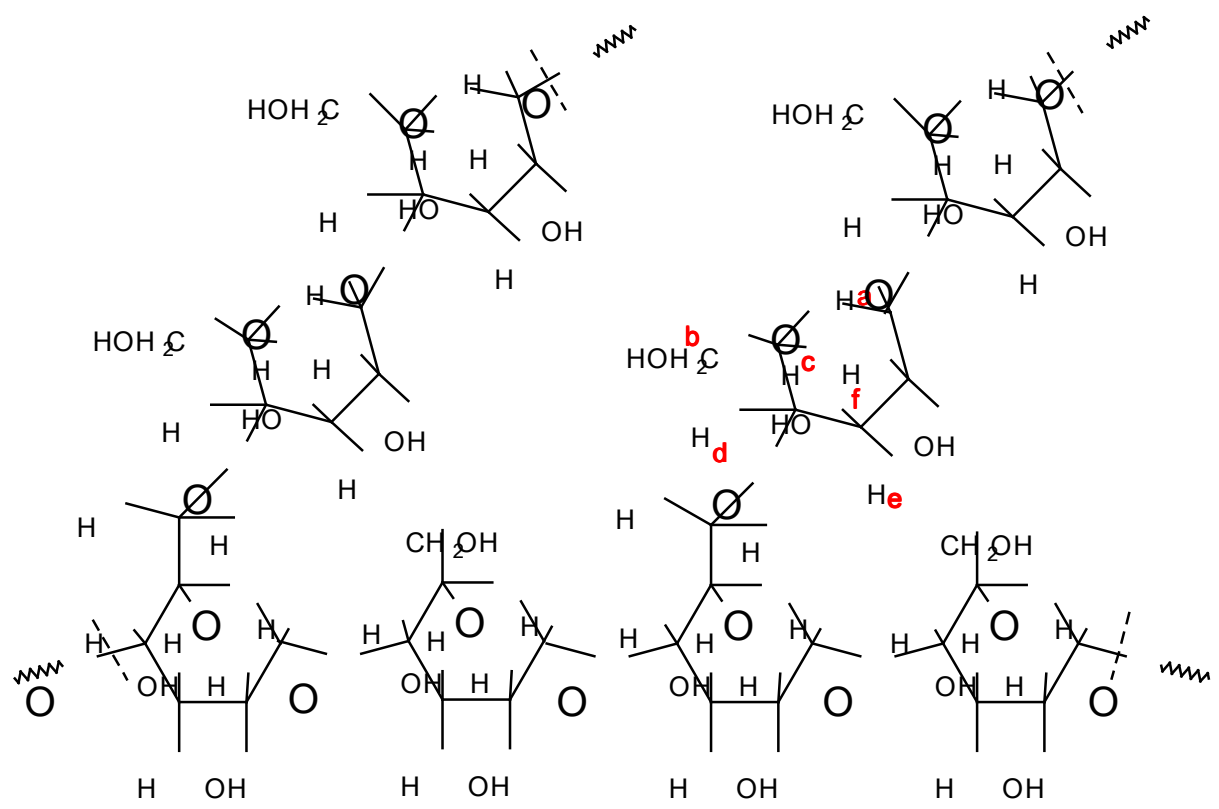

Figura 4.1 - Estrutura química para o amido nativo discriminando os hidrogênios. 


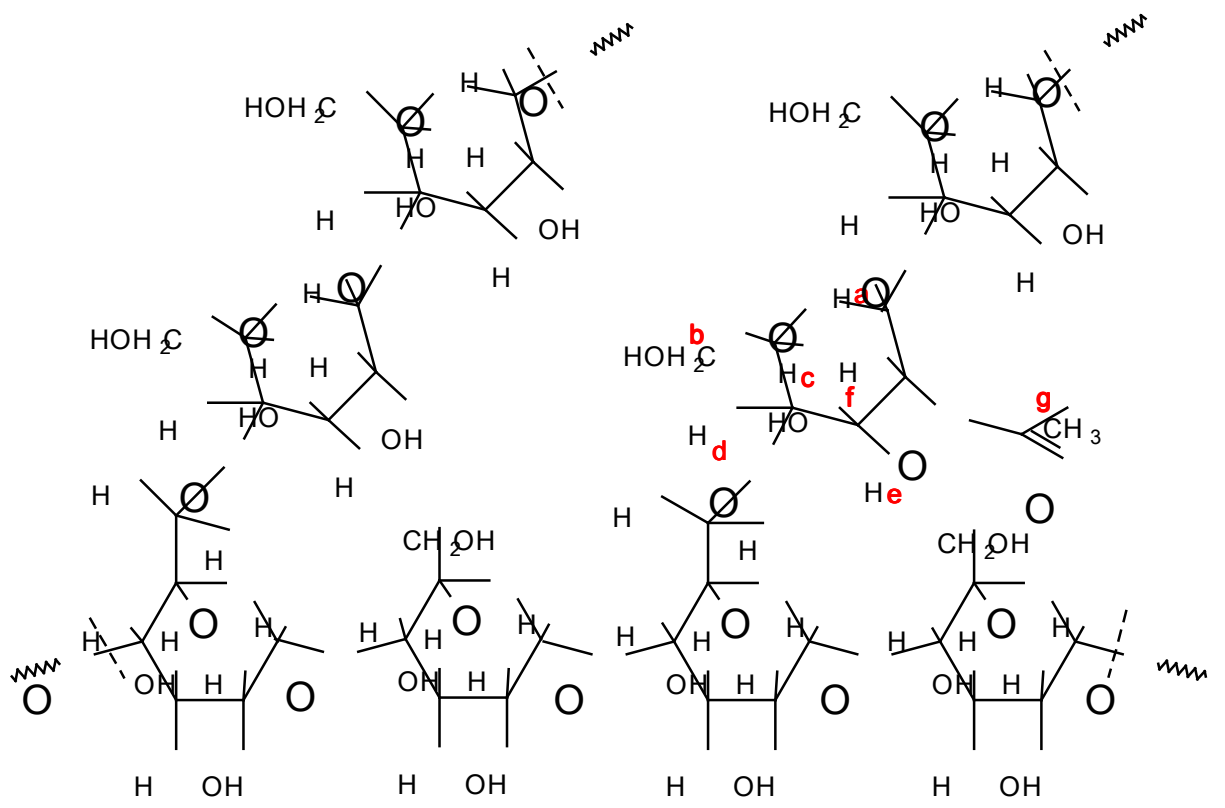

Figura 4.2 - Estrutura química para o amido acetilado discriminando os hidrogênios.

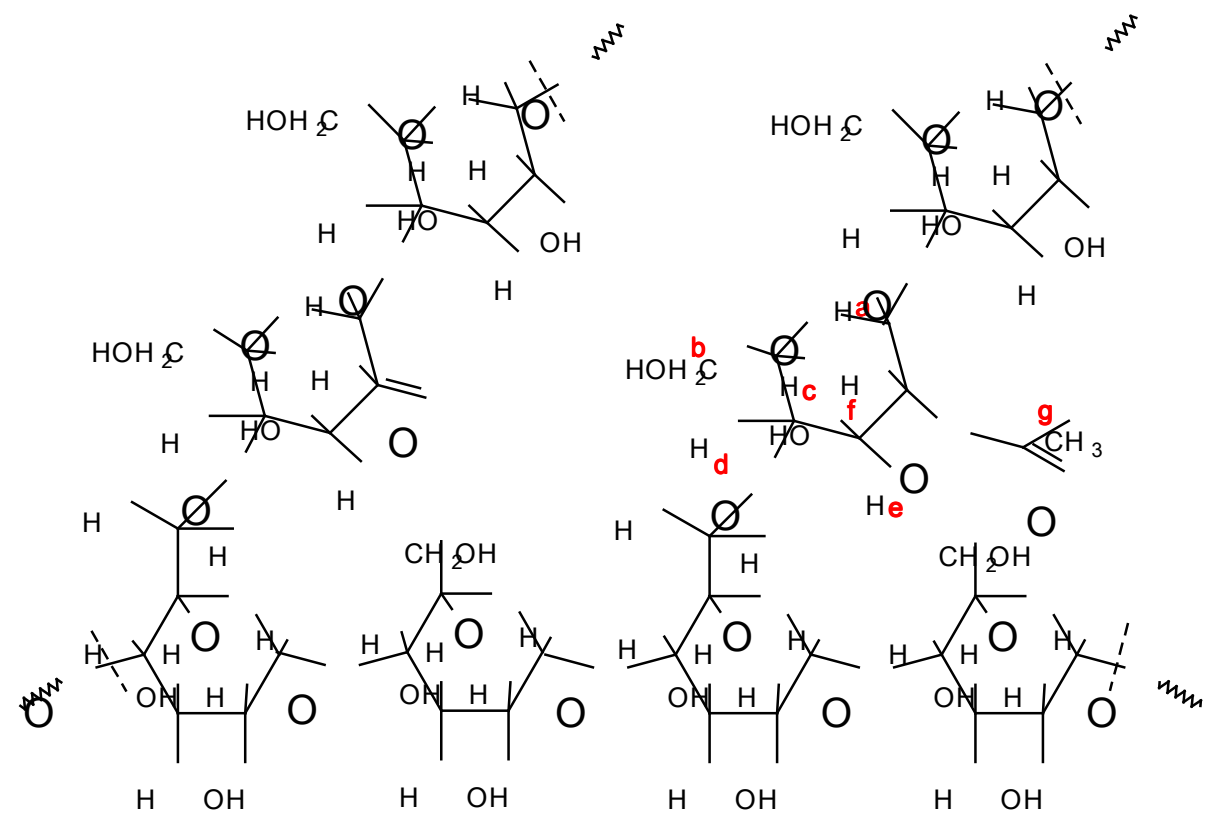

Figura 4.3 - Estrutura química para o amido oxidado-acetilado discriminando os hidrogênios. 
Espectros de RMN de macromoléculas são usualmente diferentes dos espectros apresentados pelas moléculas de baixa massa molar de igual constituição química. Isto ocorre devido às características particulares das macromoléculas, tal como alta viscosidade e baixa mobilidade. Obviamente os sinais detectados são referentes às unidades repetitivas do polímero em questão. No entanto, quando há diferentes configurações da cadeia polimérica, aparecem no espectro do polímero outros picos referentes a um mesmo grupo ou unidade repetitiva, os quais não são equivalentes magneticamente.

Pode-se observar nos espectros de ${ }^{1} \mathrm{H}-\mathrm{RMN}$ (Figura 4.4), a presença dos picos em: 2,05 ppm para o amido acetilado e 2,03 e 1,85 ppm para o amido oxidado-acetilado que indicam a formação do grupo acetila, no entanto o valor obtido de $1,85 \mathrm{ppm}$ nos indica que pode ter ocorrido quebra de algumas cadeias poliméricas durante o processo de oxidação ${ }^{1}$. Os valores de deslocamento químico para os hidrogênios das amostras analisadas por ${ }^{1} \mathrm{H}-\mathrm{RMN}$ estão apresentados na Tabela 4.1. 


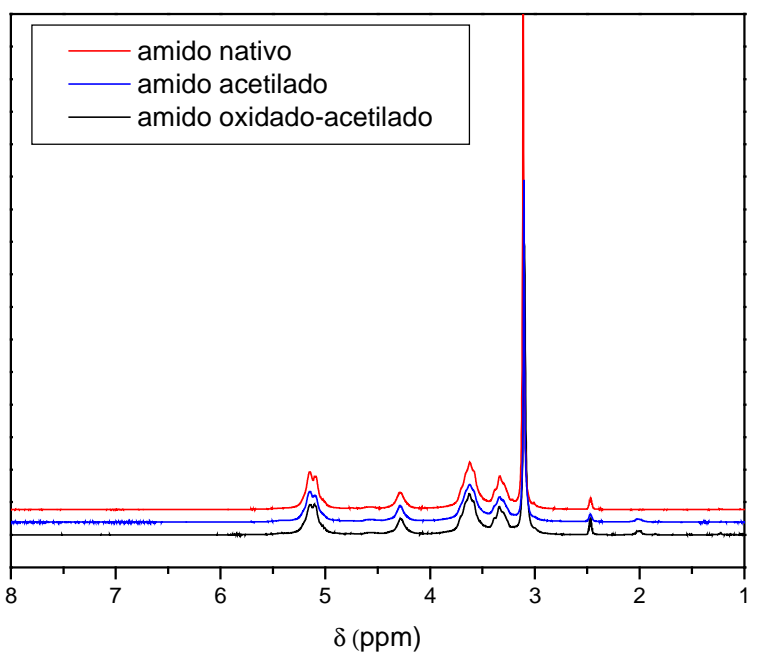

(A)

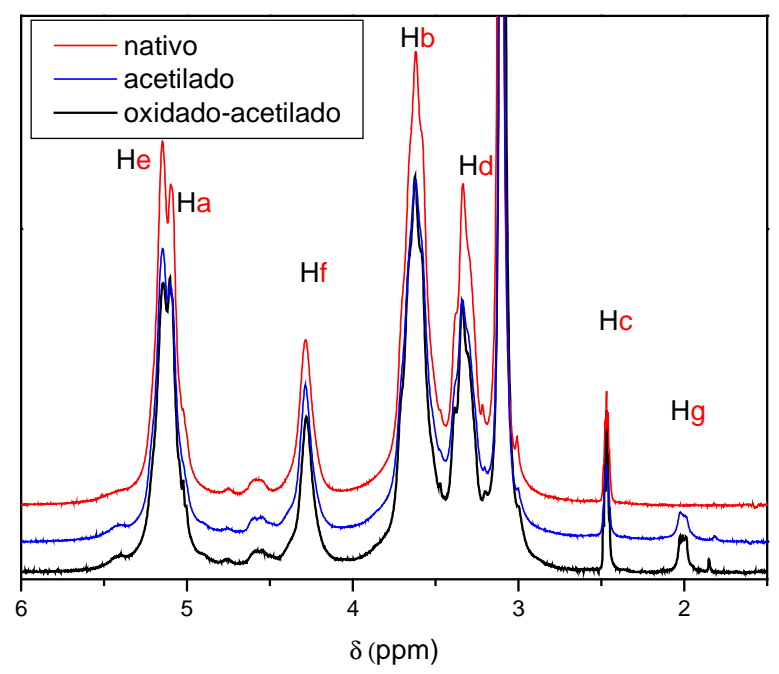

(B)

Figura 4.4 - Espectro de ${ }^{1} \mathrm{H}$ - RMN inteiro (A) e espectro ampliado (B) para o amido nativo e os amidos modificados.

Tabela 4.1 - Deslocamento químico para os hidrogênios

\begin{tabular}{|c|c|c|c|c|c|c|c|}
\hline & $\begin{array}{c}\mathrm{He} \\
(\mathrm{ppm})\end{array}$ & $\begin{array}{c}\mathrm{Ha} \\
(\mathrm{ppm})\end{array}$ & $\begin{array}{c}\mathrm{Hf} \\
(\mathrm{ppm})\end{array}$ & $\begin{array}{c}\mathrm{Hb} \\
(\mathrm{ppm})\end{array}$ & $\begin{array}{c}\mathrm{Hd} \\
(\mathrm{ppm})\end{array}$ & $\begin{array}{c}\mathrm{Hc} \\
(\mathrm{ppm})\end{array}$ & $\begin{array}{c}\mathrm{Hg} \\
(\mathrm{ppm})\end{array}$ \\
\hline Amido nativo & 5,16 & 5,11 & 4,30 & 3,64 & 3,35 & 2,47 & - \\
\hline Amido acetilado & 5,16 & 5,12 & 4,30 & 3,64 & 3,35 & 2,46 & 2,05 \\
\hline $\begin{array}{c}\text { Amido oxidado } \\
\text { acetilado }\end{array}$ & 5,16 & 5,12 & 4,30 & 3,64 & 3,36 & 2,46 & $2,03 / 1,85$ \\
\hline
\end{tabular}




\subsection{2 - Espectroscopia no InfraVermelho}

Embora o espectro de infravermelho seja característico da molécula como um todo, certos grupos de átomos dão origem a bandas que ocorrem mais ou menos na mesma freqüência, independentemente da estrutura da molécula. É justamente a presença destas bandas características de grupos que permite ao químico a obtenção, através de simples exame do espectro e consulta a tabelas, de informações estruturais úteis e é neste fato que foi feita a identificação de estruturas.

Através desta técnica pode-se observar algumas mudanças estruturais na molécula, ou seja, principalmente se houver desaparecimento ou a formação de novos grupos químicos, os quais são claramente detectados no infravermelho, assim, estas evidências permitem deduzir se ocorreu ou não algum tipo de reação química.

Os espectros de infravermelho para os amidos: nativo, acetilado e oxidado-acetilado estão apresentados na Figura 4.5, em que se pode observar uma banda larga em $3397 \mathrm{~cm}^{-1}$ atribuída ao estiramento dos grupos hidroxila $\mathrm{O}-\mathrm{H}$, que participam de formação de ligações de hidrogênio inter e intramoleculares. As bandas em 2934 e $2887 \mathrm{~cm}^{-1}$ são referentes ao estiramento assimétrico C-H, $1653 \mathrm{~cm}^{-1}$ a água adsorvida e em 1438 e $1360 \mathrm{~cm}^{-1}$ a deformação angular da ligação C-H. O estiramento da ligação C-O de éter aparece em $1164 \mathrm{~cm}^{-1}$ e o estiramento da ligação C-O de álcool em $1087 \mathrm{~cm}^{-1}$. As principais bandas, que confirmam a modificação conferida ao amido, podem ser observadas através das absorbâncias em $1747 \mathrm{~cm}^{-1}$ do estiramento $\operatorname{dos} \mathrm{C}=\mathrm{O}$. 


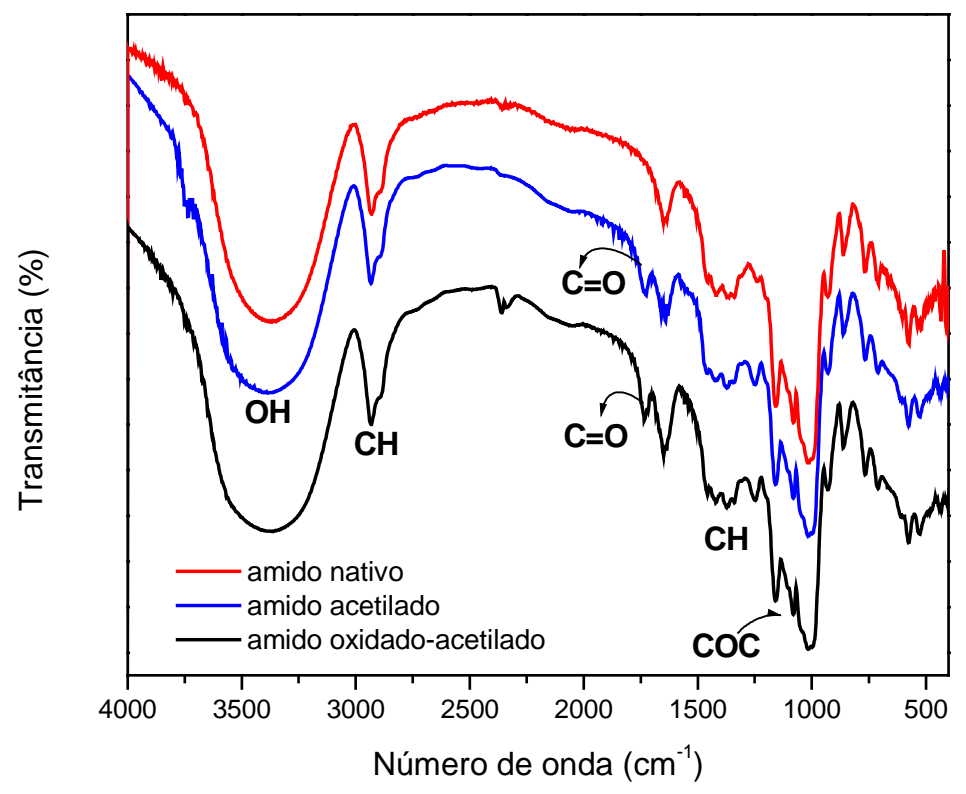

Figura 4.5 - Espectro de FTIR para o amido nativo e os amidos modificados: acetilado e oxidado-acetilado.

\subsection{3 - Cromatografia de Permeação em Gel (GPC)}

Para obter os valores das massas moleculares das amostras, as mesmas foram submetidas às análises por GPC. A curva de calibração (Figura 4.6) foi obtida utilizando-se como padrões Pullulan , um tipo de polissacarídeo microbiológico, com pesos moleculares variando de 180 a 1.600.000 Mw, conforme pode ser observado na Tabela 4.2. 
Tabela 4.2 - Padrões utilizados para curva de calibração - GPC

\begin{tabular}{|c|c|c|}
\hline PULLULAN - Mw & $\operatorname{Tr}\left(\mathrm{IR} / 35^{\circ} \mathrm{C}\right)$ & $\operatorname{Tr}(\mathrm{UV}-254 \mathrm{~nm})$ \\
\hline 1.600 .000 & 22,84 & \multirow{10}{*}{ Não absorve } \\
\hline 380.000 & 24,58 & \\
\hline 212.000 & 25,45 & \\
\hline $\mathbf{1 0 0 . 0 0 0}$ & 26,72 & \\
\hline 48.000 & 28,01 & \\
\hline 23.700 & 29,39 & \\
\hline 12.200 & 30,51 & \\
\hline 5.800 & 31,90 & \\
\hline 738 & 35,48 & \\
\hline 180 & 37,18 & \\
\hline
\end{tabular}

PULLULAN 1 = 1.600.000/100.000/12.200/180

PULLULAN 2=380.000/48.000/5.800

PULLULAN 3 $=212.000 / 23.700 / 738 \quad$ Conc.padrões $=0,0030 \mathrm{~g} \mathrm{~cd} / 2 \mathrm{~mL}$ eluente 


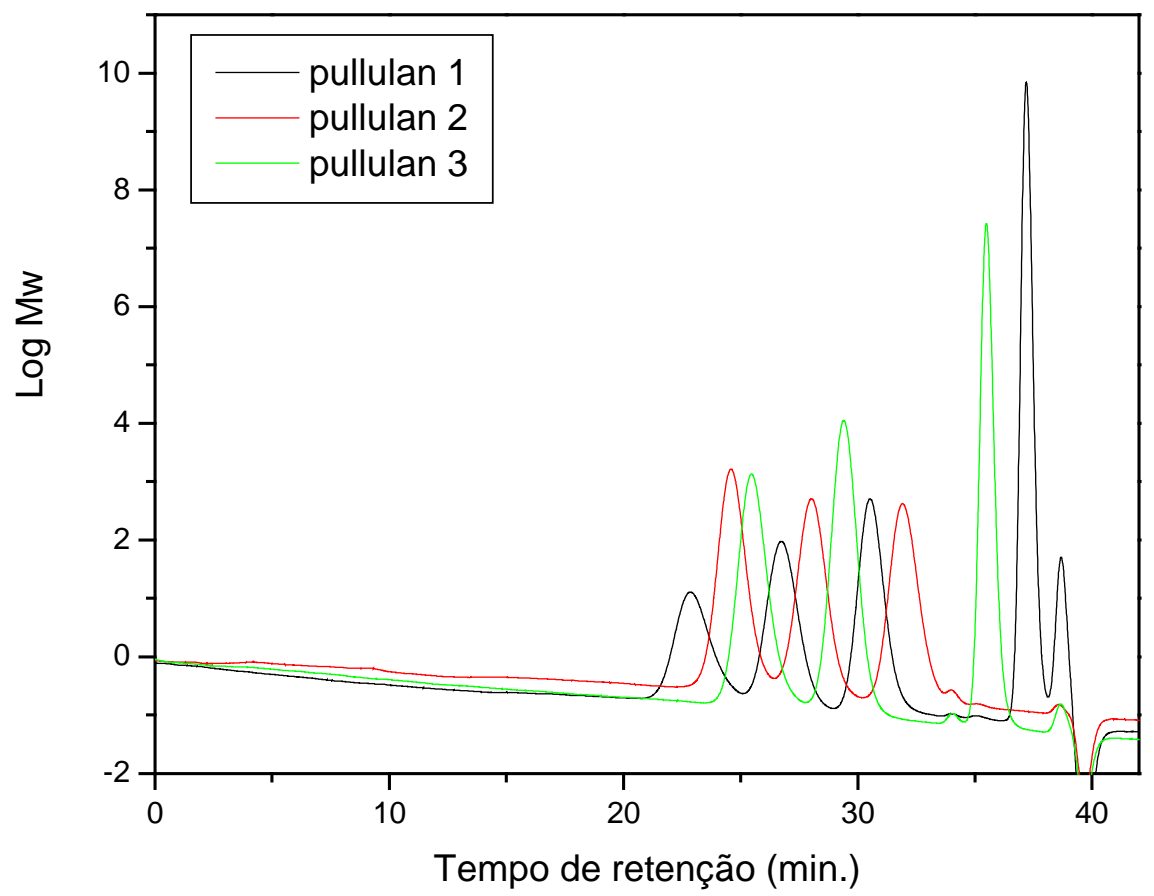

Figura 4.6 - Curva de Calibração.

Os valores obtidos das análises de GPC nos permitem verificar que as modificações conferidas ao amido alteraram pouco sua distribuição de massa molar, sendo obtido valores de massa molecular média $(\mathrm{Mw})$ na ordem de $10^{6}$ Daltons. Estes valores estão apresentados na Tabela 4.3.

Tabela 4.3 - Resultados obtidos por GPC

\begin{tabular}{|c|c|c|c|}
\hline Amostra de amido & $\boldsymbol{M w}$ & $\boldsymbol{M n}$ & $\boldsymbol{M w} / \boldsymbol{M n}$ \\
\hline Nativo & $1,43 \times 10^{6}$ & 226 & 6,32 \\
\hline Acetilado c/ aquecimento & $1,51 \times 10^{6}$ & 192 & 7,86 \\
\hline Oxidado-acetilado & $1,06 \times 10^{6}$ & 75 & 13,99 \\
\hline
\end{tabular}


Analisando os resultados desta tabela observa-se que o amido acetilado apresentou um pequeno aumento na massa molar média em relação ao amido nativo, o que pode ser devido a inserção dos grupos acetila. $\mathrm{O}$ mesmo seria esperado para o amido oxidado-acetilado, no entanto foi verificada uma diminuição deste valor de $1,43 \times 10^{6}$ (para o amido nativo) para $1,06 \times 10^{6}$ (amido oxidado-acetilado). A explicação para isso pode ser feita através das curvas de distribuição de massa molecular das amostras analisadas, apresentadas nas Figuras 4.7, 4.8 e 4.9. Ao observar a curva de distribuição de massa molecular (DPM) para o amido oxidado-acetilado (Figura 4.8), verificou-se uma distribuição com característica trimodal, o que indica a possibilidade de ocorrência de cisões na molécula durante o processo de modificação química do amido. Este fato pode ser comprovado também pelo aumento da polidispersividade (Mw/Mn), o que significa que ocorreu quebra das cadeias poliméricas devido provavelmente às reações de modificação.

Durante a oxidação ocorre a quebra das ligações $\alpha$-D 1,4 e $\alpha$-D 1,6, como a ligação $\alpha$-D 1,4 é a responsável pela ligação entre os monômeros de glicose, a oxidação causa diminuição de comprimento das cadeias, o que reduz drasticamente a viscosidade e conseqüentemente sua distribuição de massa molecular ${ }^{1}$. 


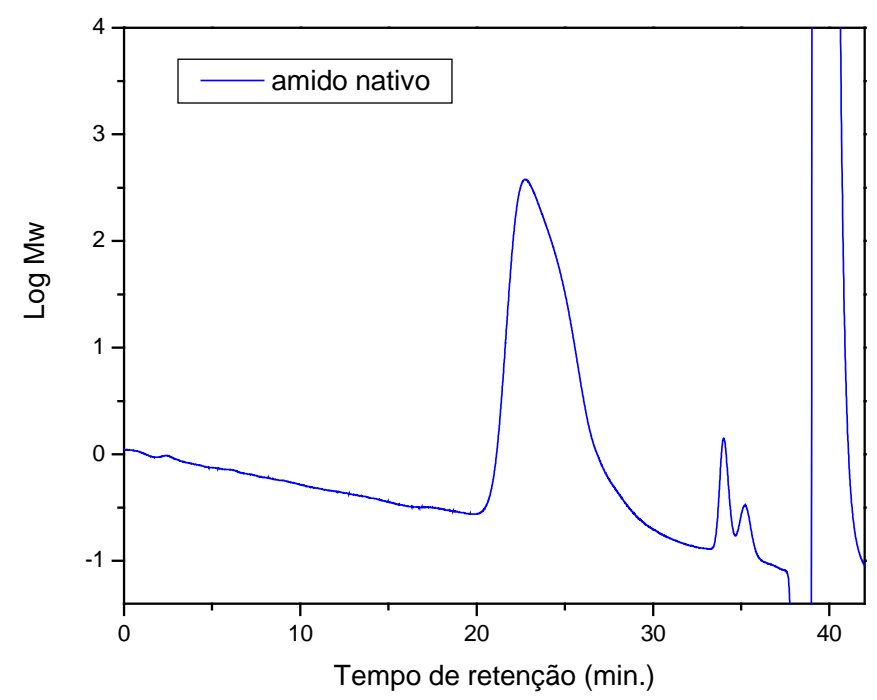

Figura 4.7 - DPM do amido nativo.

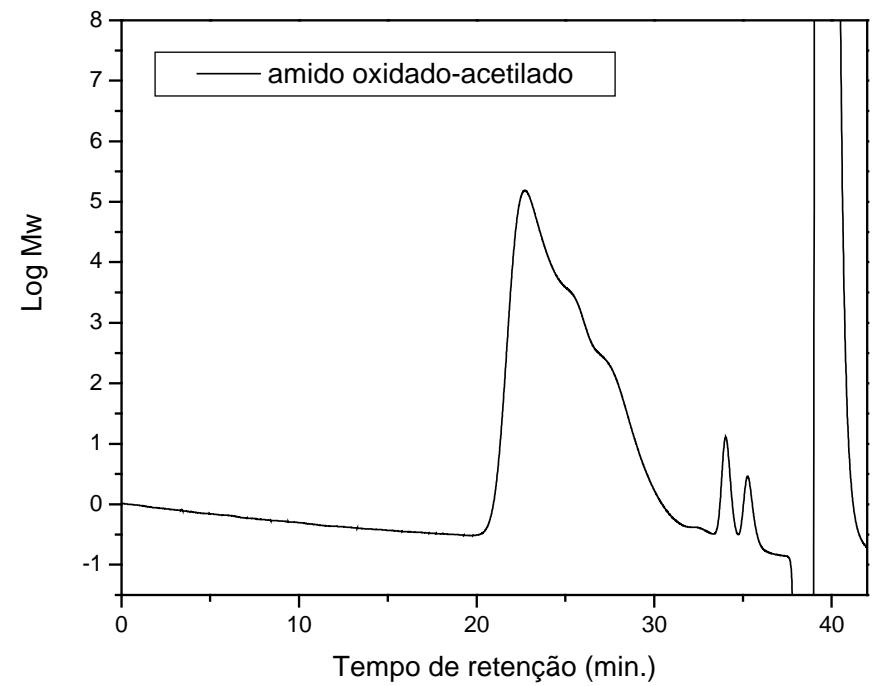

Figura 4.8 - DPM do amido oxidado-acetilado. 


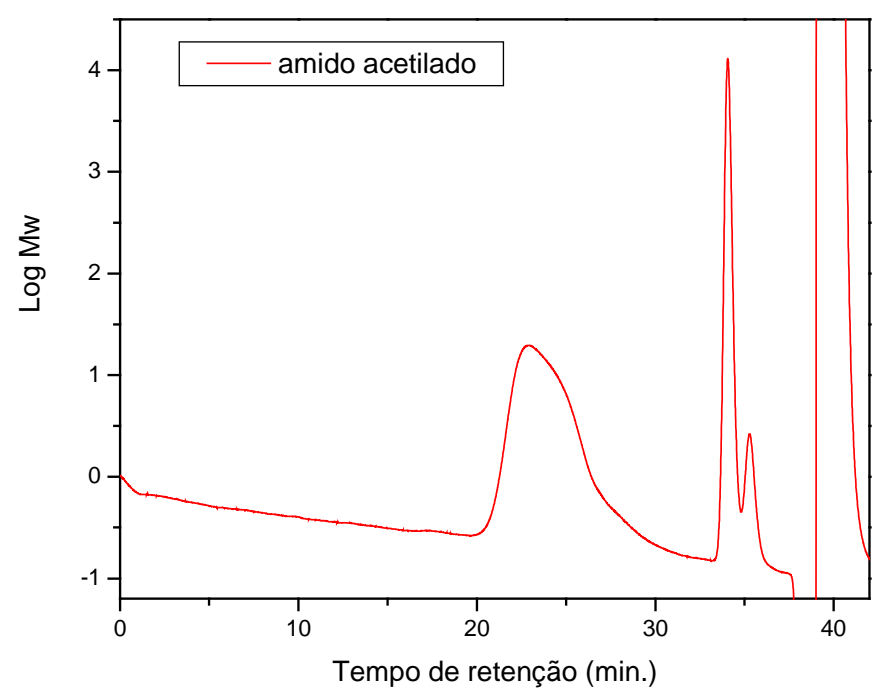

Figura 4.9 - DPM do amido acetilado.

\subsection{4 - Determinação do grau de substituição}

O Grau de Substituição (DS) do amido fornece informação da magnitude da modificação conferida ao amido submetido às reações de oxidação e acetilação. O DS foi calculado de acordo com o método de Wurzburg ${ }^{2}$, como apresentado no capítulo 3, sendo:

$$
\mathrm{DS}=[(25-\mathrm{x}) * 0,043 * 0,5 * 100] / \mathrm{a}
$$

Onde: $25=$ volume de $\mathrm{NaOH}(0,5 \mathrm{M})$ adicionado na amostra,

$\mathrm{x}=$ volume de $\mathrm{HCl}(0,5 \mathrm{M})$ usado na titulação da amostra,

$0,043=$ constante

0,5 = molaridade das soluções de $\mathrm{NaOH}$ e $\mathrm{HCl}$ utilizadas,

$\mathrm{a}=$ massa de amostra de amido seco. 
Os valores de DS encontrados para o amido acetilado foi de 1,24 e para o amido oxidadoacetilado foi de 2,57. Segundo Wurzburg $^{2}$ a interpretação deste resultado revela a presença de 1,24 mols de carbonila por mol de D-glucose no amido acetilado e 2,57 mols de carbonila por mol de D-glucose no amido oxidado-acetilado.

\subsection{5 - Análise elementar}

Com o objetivo de verificar se houve alteração da composição química do amido frente às modificações conferidas, foram realizadas medidas de análise elementar. Por meio dessa técnica foram quantificados os teores de carbono, oxigênio, nitrogênio e enxofre nas amostras de amido nativo, amido acetilado e amido oxidado-acetilado. Os resultados dessas análises estão expressos na Tabela 4.4.

Tabela 4.4 - Teores de C, H e O do amido nativo, amido acetilado e amido oxidado-acetilado

\begin{tabular}{|c|c|c|c|c|}
\hline \multirow{2}{*}{} & \multicolumn{2}{|c|}{ Amido nativo } & Amido acetilado & $\begin{array}{c}\text { Amido oxidado- } \\
\text { acetilado }\end{array}$ \\
\cline { 2 - 5 } & teórico & obtido & obtido & obtido \\
\hline$(\%) \mathrm{C}$ & 44,4 & 39,4 & 39,6 & 39,2 \\
\hline$(\%) \mathrm{H}$ & 6,2 & 6,4 & 5,7 & 6,5 \\
\hline$(\%) \mathrm{O}$ & 49,4 & 54,2 & 54,7 & 54,3 \\
\hline
\end{tabular}

A Tabela 4.4 revela que as porcentagens de $\mathrm{C}, \mathrm{H}$, e $\mathrm{O}$ para as diferentes amostras diferem muito pouco do valor teórico calculado para amido nativo, bem como entre as diferentes amostras. Essas diferenças possivelmente são decorrentes do fato de haver impurezas nas amostras em análise e também devido ao baixo DS encontrado para o amido acetilado. 
No caso do amido oxidado-acetilado, embora o DS obtido ser praticamente o dobro do valor obtido para o amido acetilado, a diminuição da quantidade de oxigênio e o aumento da quantidade de hidrogênio presentes na amostra nos indica que realmente ocorreu quebra de ligações durante o processo de modificação deste amido, como observado através das análises por RMN e GPC.

O valor teórico foi calculado baseando-se na estrutura apresentada anteriormente na Figura 4.1, onde considerou-se para o cálculo o monômero da amilose $\left(\mathrm{C}_{6} \mathrm{H}_{10} \mathrm{O}_{5}\right) \mathrm{n}$.

\section{2 - Caracterização dos Filmes de Amido Plastificados}

\subsection{1 - Escolha do plastificante}

Para que um eletrólito sólido polimérico seja utilizado em dispositivos eletrocrômicos é necessário que este possua um bom valor de condutividade iônica, ou seja, acima de $10^{-5} \mathrm{~S} / \mathrm{cm}$, a temperatura ambiente, seja transparente na região do visível e tenha boa aderência aos eletrodos. O polímero mais utilizado como eletrólito sólido é o poli (óxido de etileno) (PEO), no entanto, o mesmo à temperatura ambiente, possui uma condutividade em torno de $10^{-7} \mathrm{~S} / \mathrm{cm}^{3}$. Com o intuito de melhorar as condutividades destes polímeros várias modificações físicas e químicas são realizadas. Uma das modificações físicas que pode ser utilizada, sendo esta bastante simples e barata, é a adição de um plastificante, geralmente uma substância de baixa massa molecular e viscosidade $^{3,4,5}$. Ao introduzir esta substância, observa-se uma diminuição da cristalinidade e da temperatura de transição vítrea do polímero, favorecendo desta forma a solvatação e migração do sal. Outro aspecto muito importante que merece ser mencionado é o fato de que geralmente os 
plastificantes possuem valores relativamente altos de constante dielétrica, fazendo com que os mesmos auxiliem na solvatação dos íons, aumentando assim a condutividade iônica.

A escolha de um bom plastificante é de suma importância para que tenha a formação de um bom filme e para que este apresente um ótimo valor de condutividade. Como já foi comentado anteriormente, um plastificante com alta constante dielétrica e baixa viscosidade é de certa forma um bom pré-requisito para que esta substância seja utilizada. Entretanto, somente estes dois fatores não são suficientes para garantir que esta substância propiciará ótimos resultados, tanto com relação à interação com o polímero, quanto a um aumento na condutividade. Portanto, pode-se notar que a escolha de um bom plastificante, para o polímero, depende de algumas variáveis para que este possa ser utilizado com sucesso. Desta forma, neste trabalho, foi estudado o efeito de três plastificantes: glicerol, sorbitol e etileno glicol, no comportamento da condutividade iônica dos amidos.

Na Tabela 4.5 estão sendo apresentados os valores de constante dielétrica e de viscosidade para três plastificante, juntamente com as suas fórmulas estruturais. 
Tabela 4.5 - Valores de constante dielétrica, viscosidade e a fórmula estrutural para cada plastificante $^{6}$

\begin{tabular}{|c|c|c|c|}
\hline & $\begin{array}{l}\text { Constante } \\
\text { dielétrica }\end{array}$ & $\begin{array}{c}\text { Viscosidade (cp) } \\
25^{\circ} \mathrm{C}\end{array}$ & $\begin{array}{l}\text { Fórmula } \\
\text { estrutural }\end{array}$ \\
\hline Sorbitol & - & 110 & 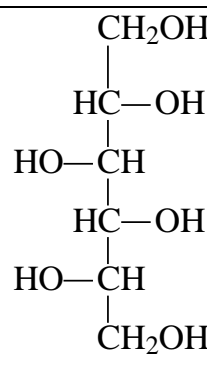 \\
\hline Glicerol & 42,5 & 979 & $\begin{array}{c}\mathrm{H}_{2} \mathrm{C}-\mathrm{OH} \\
\mathrm{HC}-\mathrm{OH} \\
\mathrm{H}_{2} \mathrm{C}-\mathrm{OH}\end{array}$ \\
\hline Etileno glicol & 38 & 17,3 & $\begin{array}{l}\mathrm{H}_{2} \mathrm{C}-\mathrm{OH} \\
\mathrm{H}_{2} \mathrm{C}-\mathrm{OH}\end{array}$ \\
\hline
\end{tabular}

Como já mencionado anteriormente, o amido é um polímero semicristalino constituído de grânulos. Ao promover a plastificação do amido através da adição de plastificantes como o glicerol, ocorre uma modificação na sua estrutura como mostra a Figura 4.10. Nesta figura podese observar as modificações conferidas na estrutura do amido com o uso de diferentes tipos de plastificantes: sorbitol, glicerol e etileno glicol.

Um primeiro critério a ser adotado na escolha de um plastificante é se haverá compatibilidade entre ele e o polímero. Contudo como já verificado anteriormente com o amido de milho rico em amilopectina ${ }^{7,8}$ estes plastificantes possuem uma boa interação com o amido. A explicação para isso é que os plastificantes contendo grupamentos $\mathrm{OH}$ em sua estrutura levam uma grande vantagem com relação a outros, pois estes formaram ligações de hidrogênio com a amilopectina, facilitando desta forma a separação de suas cadeias. Assim, pode-se a princípio 
dizer que quanto maior a quantidade de hidroxilas possuir o plastificante, maior será o efeito da plastificação, sendo então, o glicerol e o sorbitol os melhores candidatos para promover a separação das cadeias.

$\mathrm{Na}$ Figura 4.10, nota-se que as amostras de amido de milho rico em amilopectina plastificadas com glicerol e com sorbitol apresentam comportamento muito semelhantes. Ambos os difratogramas mostram uma banda larga, sugerindo a predominância do estado amorfo. Também estas amostras permaneceram transparentes ${ }^{7}$. As amostras contendo etileno glicol por outro lado apresentaram-se rígidas e quebradiças, indicando que não houve uma boa plastificação do matéria. $\mathrm{O}$ difratograma de raios-X da amostra com etileno glicol revela também vários picos, indicando a presença de cristais, identificados como de $\mathrm{LiClO}_{4}{ }^{7}$.

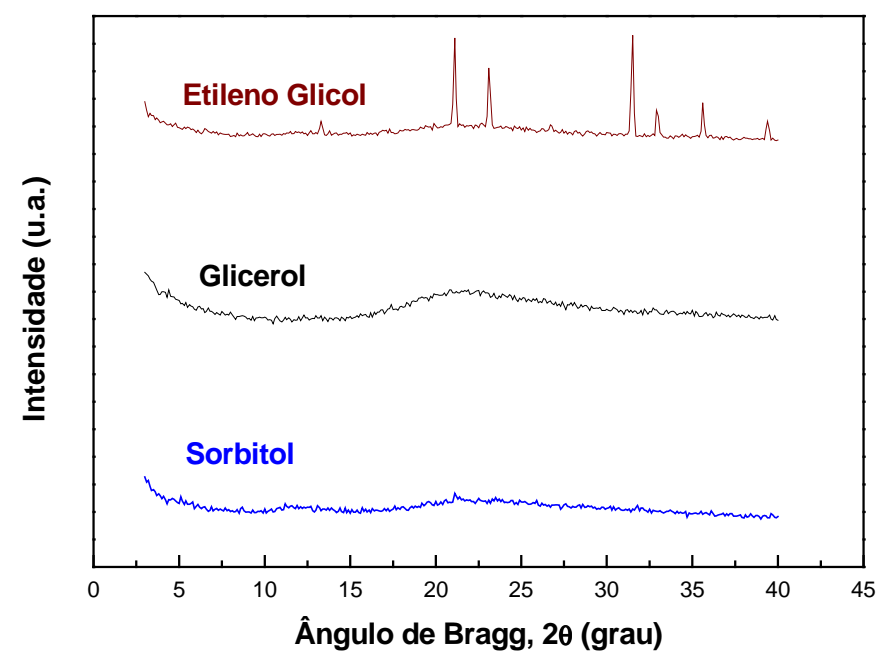

Figura 4.10 - Difratograma de raios-X de amido de milho rico em amilopectina plastificado com diferentes plastificantes, na mesma quantidade em massa $30 \%$ e com uma concentração de

$$
\mathrm{LiClO}_{4} \text { de } 10[\mathrm{O}] /[\mathrm{Li}]^{7} \text {. }
$$


$\mathrm{Na}$ Figura 4.11 estão apresentados os difratogramas de raios-X para os amidos de mandioca plastificados com glicerol, etileno glicol e sorbitol, nota-se que estas amostras apresentam comportamento predominantemente amorfo para os três plastificantes utilizados.

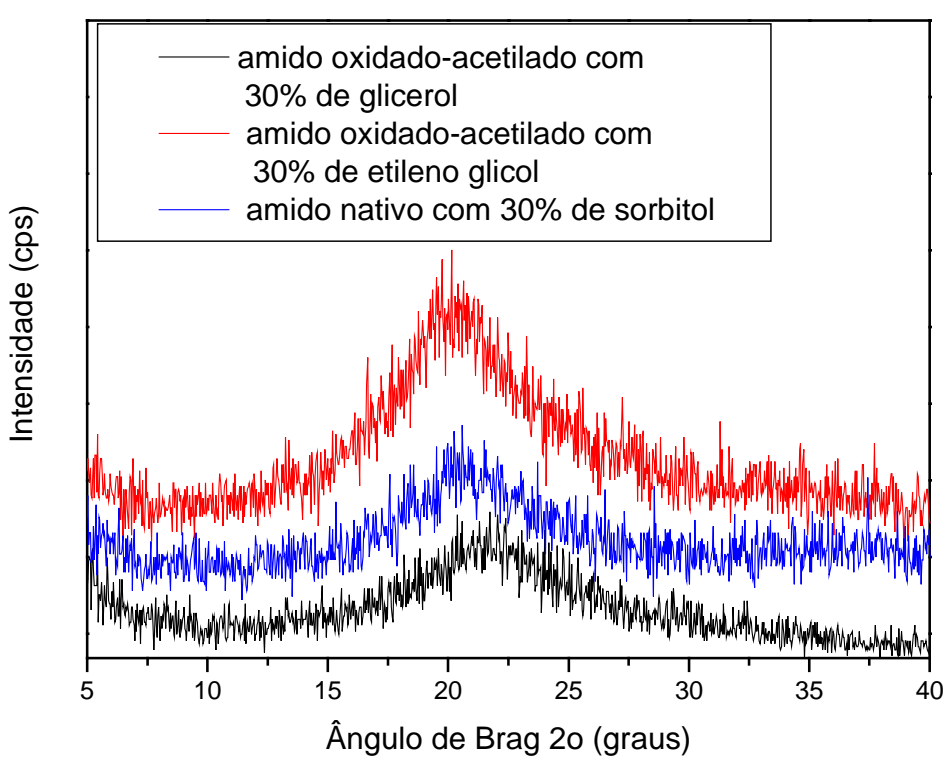

Figura 4.11 - Difratograma de raios-X de amido de mandioca nativo plastificado com sorbitol e amido de mandioca oxidado-acetilado plastificado com glicerol e etileno glicol, na mesma quantidade em massa (30\%) de plastificante e com uma concentração de $\mathrm{LiClO}_{4}$ de $10[\mathrm{O}] /[\mathrm{Li}]$.

O etileno glicol devido ser uma molécula menor comparada com glicerol e sorbitol, possui uma tendência maior de promover a exsudação e alguns dos filmes preparados mostraramse quebradiços e pouco aderentes, entretanto através da Figura 4.11 observa-se que ocorreu mudança da estrutura cristalina do amido de mandioca modificado, ou seja ocorreu a plastificação. Trabalhos anteriores de amido de milho rico em amilopectina plastificados com etileno glicol mostraram que ocorreu plastificação do amido, pelo desaparecimento dos picos 
característicos da amilopectina pura, no entanto ocorreu o aparecimento de picos estreitos, característicos do sal de lítio adicionado. Desta forma a introdução do etileno glicol diminui a cristalinidade das amostras através da quebra de ligações de hidrogênio intermoleculares, mas nos casos de amido de milho rico em amilopectina o sal de lítio adicionado não foi totalmente dissolvido nos filmes ${ }^{8}$.

Os filmes a base de amido de mandioca (estudados neste projeto) que foram preparados com glicerol e com sorbitol mostraram-se mais maleáveis e transparentes, sendo as amostras plastificadas com glicerol se apresentaram visualmente mais transparentes e aderentes à superfície de vidro. Também estas amostras apresentaram bons resultados de condutividade, como podemos observar na Figura 4.12 onde os melhores resultados de condutividade de $10^{-}$ ${ }^{4} \mathrm{~S} / \mathrm{cm}$ foram obtidos para amostra preparada com amido acetilado, glicerol e $\mathrm{LiClO}_{4}$ na concentração de $10[\mathrm{O}] /[\mathrm{Li}]$. No caso desta amostra a mudança de plastificante para sorbitol ou etileno glicol diminui uma ordem de grandeza os valores de condutividade. A amostra preparada com amido oxidado-acetilado apresenta os valores de condutividade na ordem de grandeza menor $\left(10^{-5} \mathrm{~S} / \mathrm{cm}\right)$ quando comparada com as amostras a base de amido acetilado. Entretanto neste caso também as amostras plastificadas com glicerol apresentaram maiores valores de condutividade. Desta forma as amostras preparadas com glicerol foram mais amplamente estudadas para se comparar os diferentes ESPs a base de amido de mandioca estudados neste trabalho. 


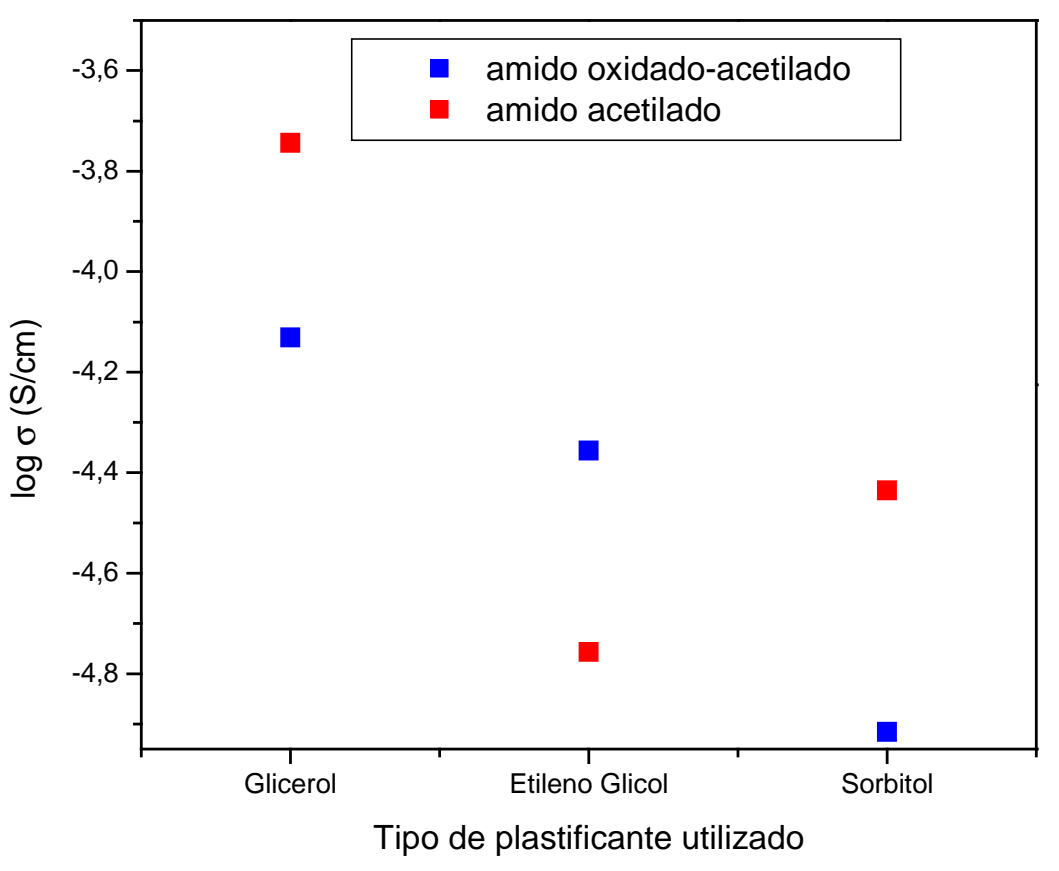

Figura 4.12 - Comparação das condutividades dos filmes de amido acetilado e amido oxidado-acetilado com diferentes plastificantes, na mesma quantidade em massa $30 \%$ e com uma concentração de $\mathrm{LiClO}_{4}$ de $10[\mathrm{O}] /[\mathrm{Li}]$.

A adição de agentes plastificantes ao amido, além de conferir a diminuição da cristalinidade, ou mesmo produzir filmes predominantemente amorfos, também contribui para um abaixamento da temperatura de transição vítrea $\left(\mathrm{T}_{\mathrm{g}}\right)$ destes filmes.

Nas Figuras 4.13, 4.14 e 4.15 pode-se observar algumas curvas de DSC obtidas para os filmes preparados, destacando-se os valores da temperatura de transição vítrea para os mesmos. 


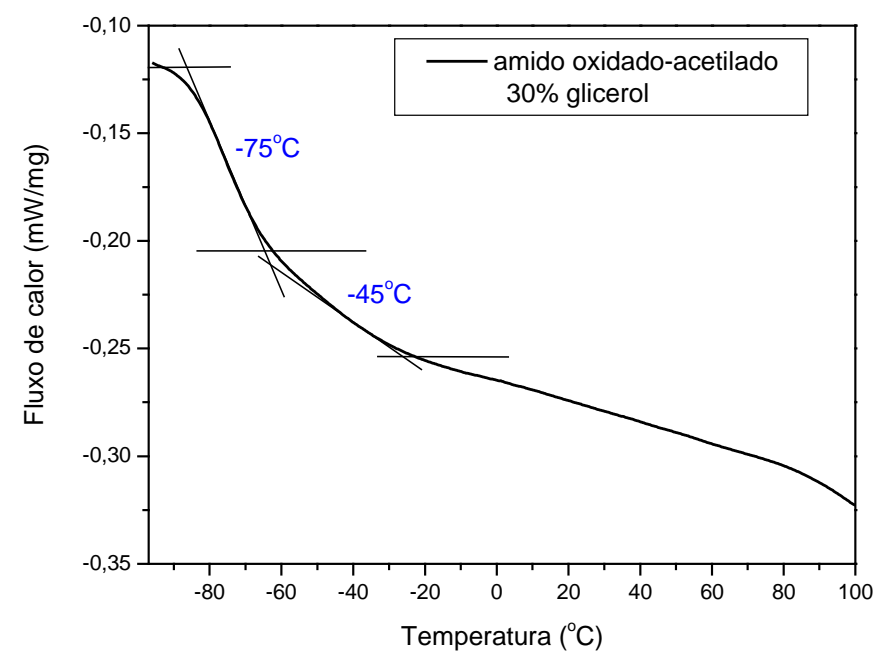

Figura 4.13 - Curva de DSC do amido oxidado-acetilado plastificado com $30 \%$ de glicerol e com uma concentração de $\mathrm{LiClO}_{4}$ de $10[\mathrm{O}] /[\mathrm{Li}]$.

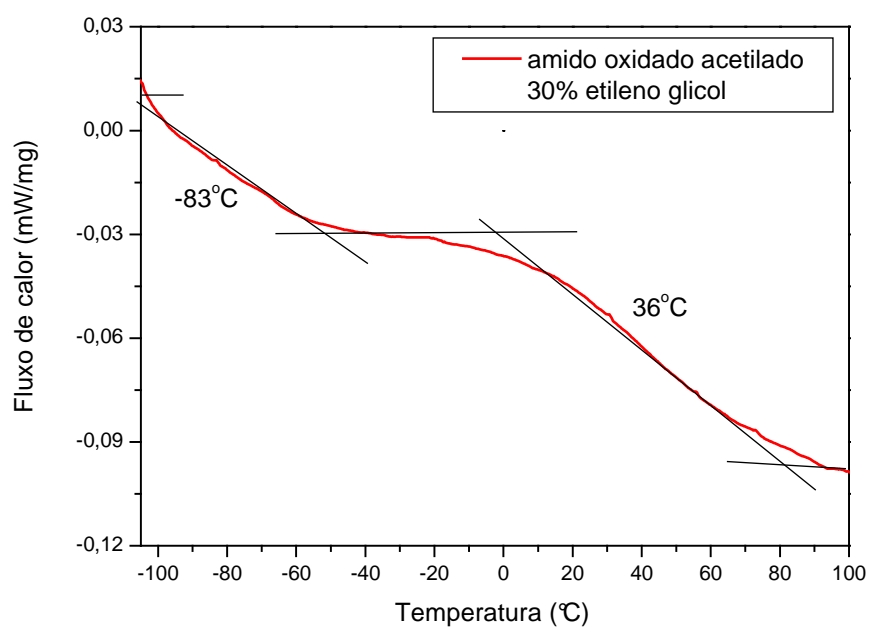

Figura 4.14 - Curva de DSC do amido oxidado-acetilado plastificado com $30 \%$ de etileno glicol e com uma concentração de $\mathrm{LiClO}_{4}$ de $10[\mathrm{O}] /[\mathrm{Li}]$. 


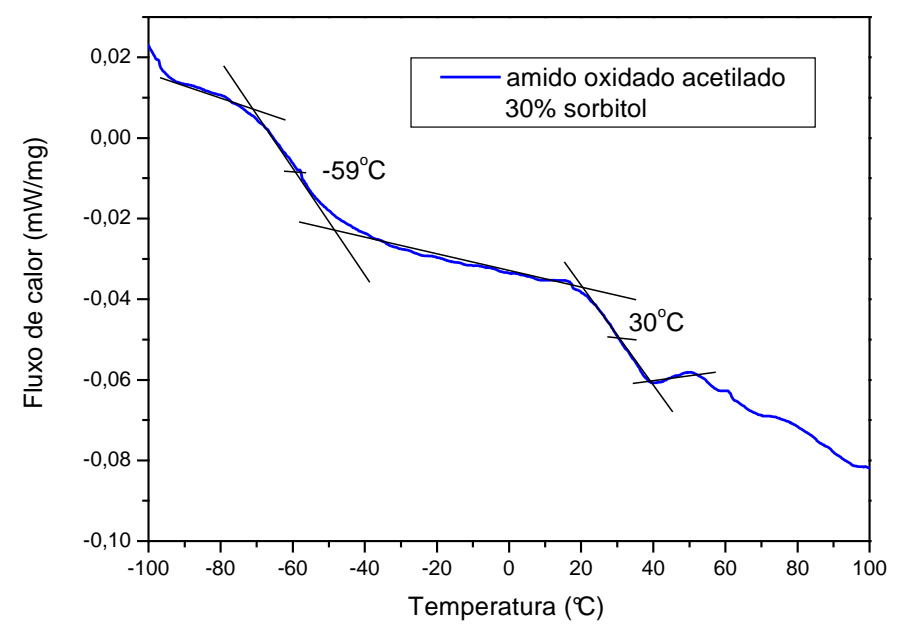

Figura 4.15 - Curva de DSC do amido oxidado-acetilado plastificado com 30\% de sorbitol e com uma concentração de $\mathrm{LiClO}_{4}$ de $10[\mathrm{O}] /[\mathrm{Li}]$.

Os valores das $\mathrm{Tg}$ das amostras de amido oxidado-acetilado variam entre $-75^{\circ} \mathrm{C}$ e $-45^{\circ} \mathrm{C}$ para amostra plastificada com glicerol,$-83^{\circ} \mathrm{C}$ e $36^{\circ} \mathrm{C}$ para amostra plastificada com etileno glicol e $-59^{\circ} \mathrm{C}$ e $30^{\circ} \mathrm{C}$ para a amostra plastificada com sorbitol. Com a adição de plastificantes e de sal de lítio observa-se, o surgimento de duas mudanças de linha de base que podem ser referentes a dois valores de $\mathrm{T}_{\mathrm{g}}$. A primeira mudança ocorre em baixa temperatura e pode ser atribuída ao glicerol ${ }^{9}$ e a segunda em temperaturas mais elevadas referente ao amido plastificado. Esta primeira mudança da linha de base é um pouco controvertida, pois alguns autores a atribuem à relaxação $\beta$, o que significa a movimentação dos pequenos fragmentos ou cadeias laterais ${ }^{9}$. A segunda mudança na linha de base é atribuída à transição $\alpha$ identificada com $T_{g}$ relativa à movimentação das cadeias do polímero, esta transição é a que influência os valores de condutividade iônica, por isso é tida como a mais importante. 


\subsection{2 - Variação da quantidade do plastificante}

A incorporação de plastificante no amido tem sido bastante explorado, devido ao fato do material obtido ser totalmente biodegradável, reduzindo assim, a agressão ao meio ambiente ${ }^{10}$.

Na Figura 4.16 pode se observar que o aumento da quantidade de glicerol, presente no filme de amido acetilado com uma quantidade de sal de lítio igual a 10[O]/[Li], ocorre um aumento da condutividade iônica. O mesmo pode ser observado na Figura 4.17, que aumentandose a quantidade de plastificante presente no filme de amido oxidado-acetilado, tanto glicerol (com uma quantidade de sal de lítio igual a 10[O]/[Li]) quanto etileno glicol (com uma quantidade de sal de lítio igual a $8[\mathrm{O}] /[\mathrm{Li}])$, ocorre aumento da condutividade iônica. Desta forma, pode-se constatar que ao aumentar a concentração de plastificante no filme ocorreu um aumento na mobilidade do íon lítio, ou seja, o plastificante (por exemplo o glicerol) além de promover o afastamento das cadeias de amilopectina, também está ajudando na solvatação dos íons, já que possui oxigênios em suas moléculas e um alto valor de constate dielétrica $(42,5)$. Isto também foi observado em outros sistemas de eletrólitos sólidos plastificados ${ }^{11,12}$. Portanto, pode-se dizer que a amilopectina seria responsável pela formação do filme, podendo também solvatar o íon lítio, no entanto o glicerol seria o principal agente responsável pela solvatação dos íons. Embora o melhor valor de condutividade foi obtido para as amostras plastificadas com 50\% de glicerol este apresenta-se, na maioria das vezes, na forma de um gel muito viscoso e não filme como outras amostras. Desta forma optou-se por utilizar filmes com $30 \%$ de glicerol, pois este além de apresentar visualmente boa propriedade mecânica também possui ótima condutividade. 


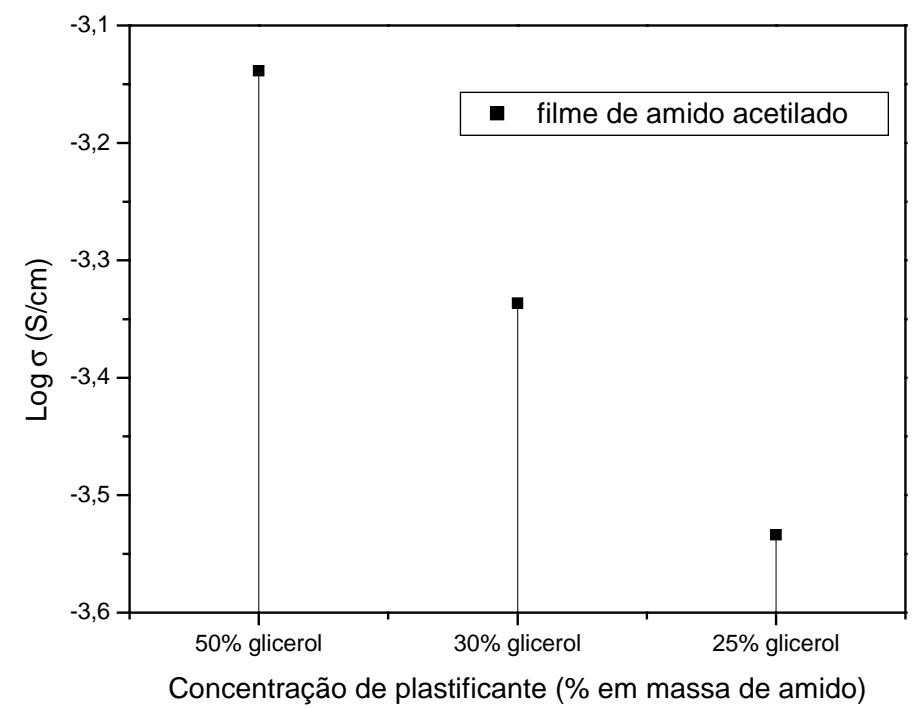

Figura 4.16 - Medidas de Log da condutividade em função da concentração de glicerol (\% em massa do amido) para filmes de amido acetilado.

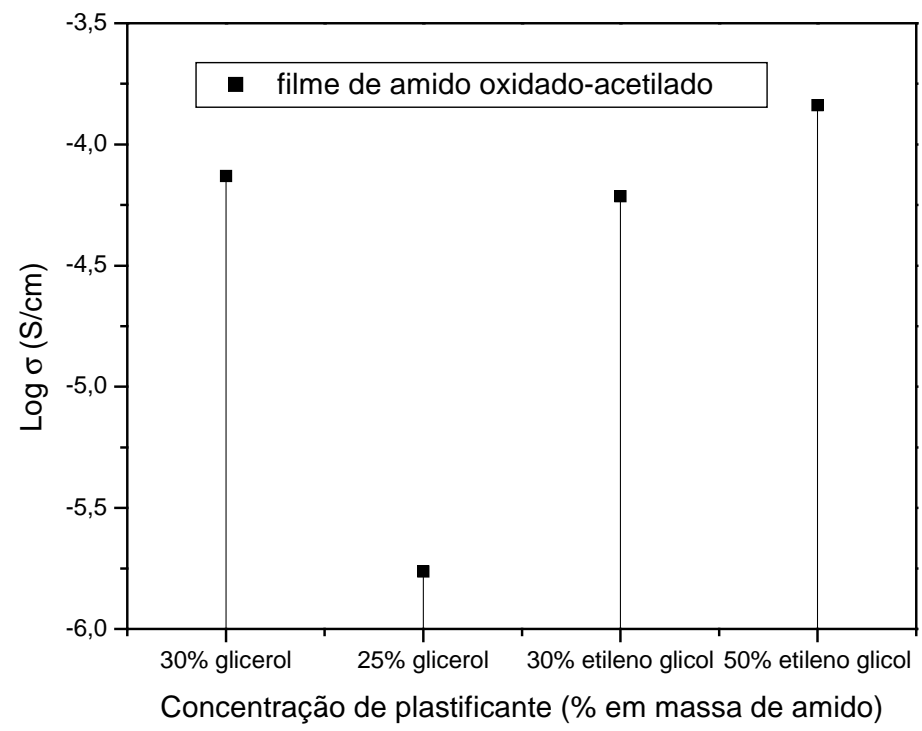

Figura 4.17 - Medidas de Log da condutividade em função da concentração de plastificante (\% em massa do amido) para filmes de amido oxidado-acetilado. 
O amido é um polímero semicristalino constituído de grânulos. A plastificação do amido através da adição de glicerol modifica a sua estrutura.

Analisando o processo em nível molecular, ocorre provavelmente a quebra das ligações de hidrogênio intra e intermoleculares, responsável em grande parte pela cristalinidade, ou seja a diminuição da probabilidade de arranjo de uma cadeia sobre a outra. Este processo resulta em filmes de amido plastificado com predominância do estado amorfo, como pode ser observado na Figura 4.18. Tanto os amidos plastificados com glicerol, ou com sorbitol apresentam as mesmas características amorfas, independentes do tipo de amido utilizado: amido de milho rico em amilopectina , amido de mandioca nativo ou modificado. Isso pode indicar que ocorreu um afastamento maior das cadeias, tornando o filme mais amorfo. No entanto, o que se pode afirmar com certeza é que estes filmes são predominantemente amorfos, o que é muito importante para sua futura utilização.

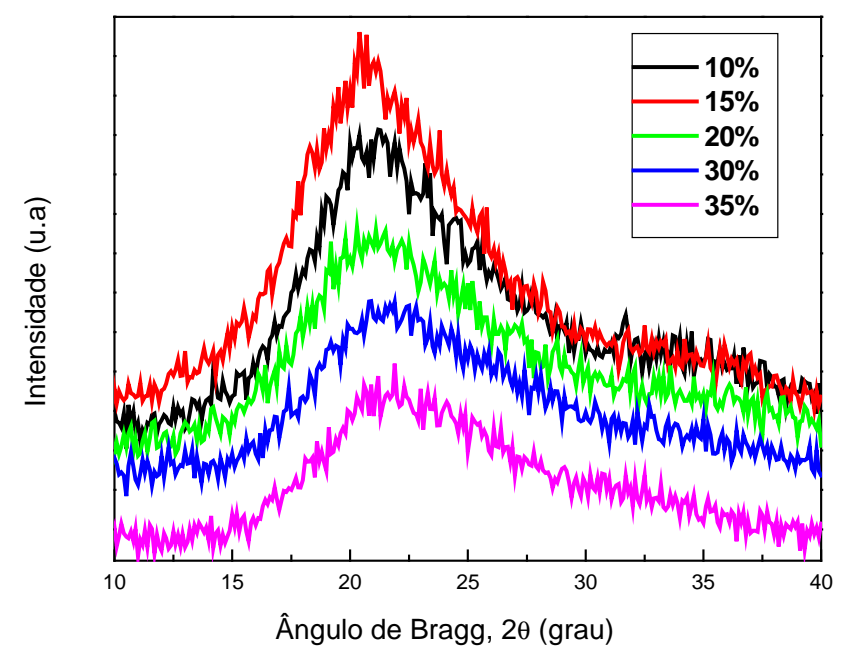

Figura 4.18 - Difração de raios-X do amido de milho rico em amilopectina plastificado com diferentes $\%$ de glicerol em massa e com $10[\mathrm{O}] /[\mathrm{Li}]^{7}$. 
A diminuição da cristalinidade das amostras a base de amido, devido ao processo de plastificação com glicerol pode ser comprovada através das análises térmicas, principalmente através dos valores de $\mathrm{T}_{\mathrm{g}}$ apresentados na Tabela 4.7. Pode-se notar que aumentando a quantidade de glicerol presente na amostra ocorre uma diminuição da $T_{g}$, isto já era esperado, pois como já foi mencionado, o glicerol promove um maior afastamento das cadeias de amilopectina, propiciando valores de $\mathrm{T}_{\mathrm{g}}$ abaixo da temperatura ambiente ${ }^{7}$.

Tabela 4.6 - Valores da temperatura de transição vítrea $\left(T_{\mathrm{g}}\right)$ de amido de milho rico em

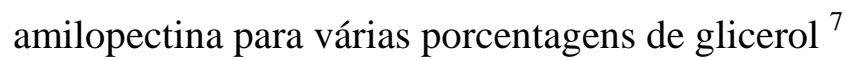

\begin{tabular}{|c|c|}
\hline \% de Glicerol & $\mathbf{T}_{\mathbf{g}}\left({ }^{\mathbf{}} \mathbf{C}\right)$ \\
\hline 15 & -13 \\
\hline 20 & -18 \\
\hline 30 & -21 \\
\hline 35 & -29 \\
\hline
\end{tabular}

As análises de DSC realizadas para os ESPs a base de amido de mandioca nativo e modificados apresentaram comportamento semelhante. Os valores de $\mathrm{T}_{\mathrm{g}}$ obtidos para amostras de amido acetilado plastificadas com glicerol em diferentes quantidades podem ser observados na Tabela 4.7, onde o aumento de plastificante promove o abaixamento de $\mathrm{T}_{\mathrm{g}}$ das amostras de $52^{\circ} \mathrm{C}$, para a amostra plastificada com $25 \%$ e glicerol para $-74^{\circ} \mathrm{C}$ para a amostra plastificada com $50 \%$ de glicerol. 
Tabela 4.7 - Valores da temperatura de transição vítrea $\left(\mathrm{T}_{\mathrm{g}}\right)$ para amostras de amido de mandioca acetilado, plastificado com diferentes porcentagens de glicerol

\begin{tabular}{|c|c|}
\hline \% de Glicerol & $\mathbf{T}_{\mathbf{g}}\left({ }^{\mathbf{}} \mathbf{C}\right)$ \\
\hline 25 & -40 \\
\hline 30 & -52 \\
\hline 50 & -60 \\
\hline
\end{tabular}

\subsection{3 - Variação da quantidade de sal de lítio}

O aumento da quantidade de sal na matriz polimérica deveria propiciar uma maior condutividade iônica, porém esta não pode ser explicada somente pela quantidade de cátions introduzidos na matriz. A associação iônica em altas concentrações de sal é um fator determinante no transporte de cargas ${ }^{13}$. Assim, a condutividade iônica aumenta com a inserção de sal até um valor limite. Após este máximo ocorre uma diminuição da condutividade, pois há a formação dos agregados iônicos, acarretando em um aumento da viscosidade e da temperatura de transição vítrea do polímero ${ }^{14}$.

Uma vez escolhida a quantidade de plastificante (glicerol) para o amido de mandioca (30\%), foram preparados diversos filmes contendo diferentes concentrações de sal de lítio, com a finalidade de se observar o máximo da condutividade para este eletrólito. Os filmes foram submetidos às medidas de impedância e as condutividades iônicas obtidas estão apresentadas na 
Figura 4.19. Neste gráfico, pode ser notado que somente a amostra a base de amido oxidadoacetilado apresentou maior valor de condutividade iônica com $8[\mathrm{O}] /[\mathrm{Li}]$ sendo $2,35 \times 10^{-4} \mathrm{~S} / \mathrm{cm}$. A amostra a base de amido acetilado teve sua condutividade maior para $10[\mathrm{O}] /[\mathrm{Li}]$, sendo $4,61 \times 10^{-4} \mathrm{~S} / \mathrm{cm}$ e a amostra a base de amido nativo com $12[\mathrm{O}] /[\mathrm{Li}]$, sendo $8,37 \times 10^{-5} \mathrm{~S} / \mathrm{cm}$.

Como citado anteriormente pode-se observar que um aumento da concentração de sal não aumenta necessariamente a condutividade. Isso pode ser verificado para as razões de 8 [O]/[Li] nas amostras de amido acetilado e $10[\mathrm{O}] /[\mathrm{Li}]$ nas amostras de amido nativo, há uma pequena diminuição da condutividade. Isto ocorre provavelmente devido à redução da mobilidade da cadeia do amido e um aumento na viscosidade do ambiente iônico causado pelos possíveis complexos iônicos formados.

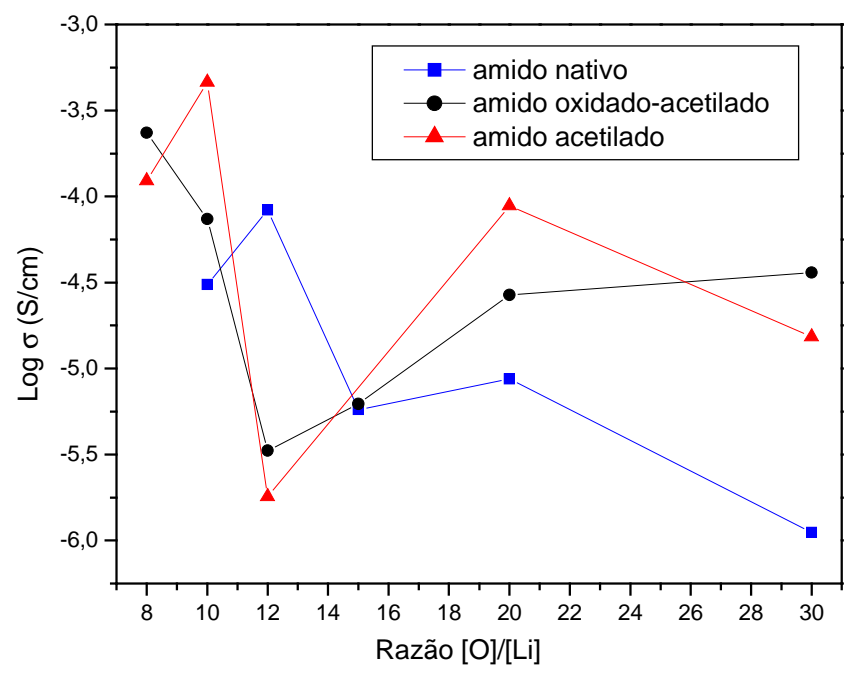

Figura 4.19 - Log da condutividade em função da razão [O]/[Li], para as amostras de amido com $30 \%$ de glicerol, a temperatura de $30^{\circ} \mathrm{C}$. 
Os resultados da condutividade em função da temperatura para os filmes de amido com $30 \%$ de glicerol e várias razões de lítio, estão apresentados na Figura 4.20. Pode ser observado que para todas as amostras analisadas há um aumento das condutividades iônicas com o aumento da temperatura.

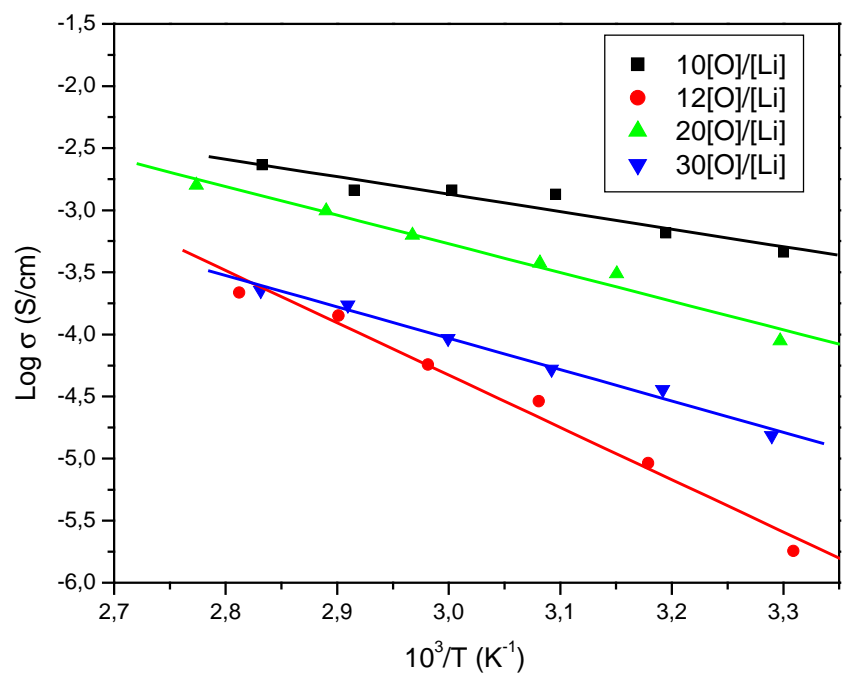

Figura 4.20 - Log da condutividade em função do inverso da temperatura, para amostras de amido acetilado e plastificado com 30\% de glicerol e com várias razões de [O]/[Li].

A Figura 4.18 mostra também uma boa concordância dos dados experimentais com a equação de Arrhenius (equação 4.1) ${ }^{15}$.

$\log \sigma=\log A+\left(-\mathrm{E}_{\mathrm{a}} / 2,303 \mathrm{RT}\right)$

onde $A$ é uma constante que independe da temperatura e é proporcional ao número de transporte iônico; $\mathrm{E}_{\mathrm{a}}$ é a energia de ativação aparente, relacionada ao deslocamento do íon e R é a constate dos gases ideais. 
Obtendo-se o coeficiente angular das retas representadas na Figura 4.20, e sabendo-se o valor de $\mathrm{R}\left(8,31441 \mathrm{Jmol}^{-1} \mathrm{~K}^{-1}\right)$, pode-se determinar a energia de ativação para cada amostra, as quais são mostradas na Figura 4.21. Estes valores são semelhantes ao publicado por Carvalho et al ${ }^{15}$, quando utilizado a equação de Arrhenius.

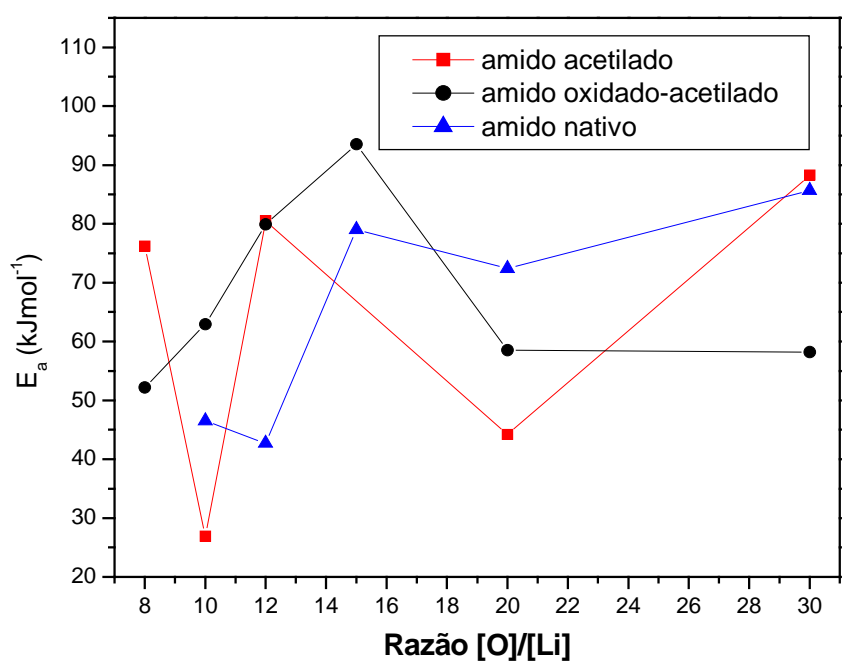

Figura 4.21 - Energia de ativação versus a razão [O]/[Li] para filmes de amido com 30\% de glicerol.

Ao comparar os valores obtidos na Figura 4.21 com os apresentados na Figura 4.19, observa-se que para os melhores valores de condutividade, a energia de ativação apresenta uma queda, ou seja, é necessário menos energia para a movimentação dos íons, desta forma há uma maior facilidade do deslocamento iônico.

As análises térmicas (DSC) de amostras de amido de mandioca plastificado mostram mudanças na linha de base que são típicas de transição vítrea $\left(\mathrm{T}_{\mathrm{g}}\right)$. Os grânulos de amilopectina com $11 \%$ de umidade possuem temperatura de transição vítrea em torno de $50^{\circ} \mathrm{C}{ }^{16}$, com uma 
capacidade calorífica, $\Delta \mathrm{Cp}=-0,012 \mathrm{~mW} / \mathrm{mg}$. Esse baixo valor de capacidade calorífica é observado para este tipo de polímero natural. Após a adição de plastificantes e do sal de lítio observa-se, uma mudança de linha de base que pode ser atribuída à $T_{g}$ relativa à movimentação das cadeias do polímero, esta transição é a que influência os valores de condutividade iônica, por isso é importante.

As amostras de amido de mandioca plastificado que apresentaram bons resultados de condutividade, da ordem de $10^{-5} \mathrm{~S} / \mathrm{cm}$, apresentaram temperatura de transição vítrea $\left(\mathrm{T}_{\mathrm{g}}\right)$ em aproximadamente $-60^{\circ} \mathrm{C}$, como pode ser observado na Figura 4.22. Esse baixo valor de $\mathrm{T}_{\mathrm{g}}$ é de muita valia para a futura aplicação deste material como eletrólito sólido polimérico, pois facilita a mobilidade dos íons.

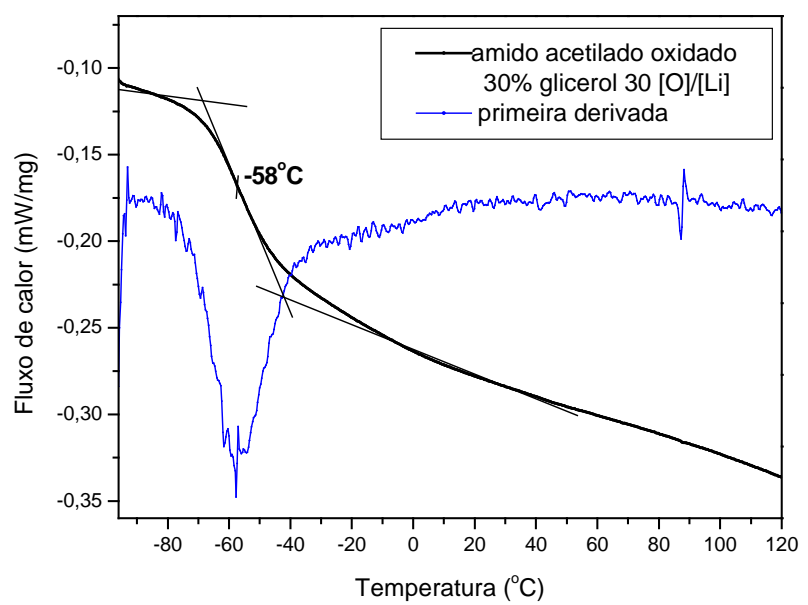

Figura 4.22 - $\mathrm{T}_{\mathrm{g}}$ da amostra de amido oxidado-acetilado plastificado com $30 \%$ de glicerol e contendo $30[\mathrm{O}] /[\mathrm{Li}]$; obtida pela primeira derivada.

O perclorato de lítio além de ser um composto explosivo ele também é bastante higroscópico, desta forma quanto maior a quantidade de sal presente na amostra, maior será a 
capacidade de absorção de água do filme. Na Figura 4.23, nota-se que com o aumento da quantidade de lítio de 20 para $15,12[\mathrm{O}] /[\mathrm{Li}]$, o valor de $\mathrm{T}_{\mathrm{g}}$ diminui. Isso pode ser explicado devido a maior quantidade de água absorvida por estes filmes, pois como foi mencionado, a água é um bom plastificante para o amido, e também auxilia na solvatação do íon.

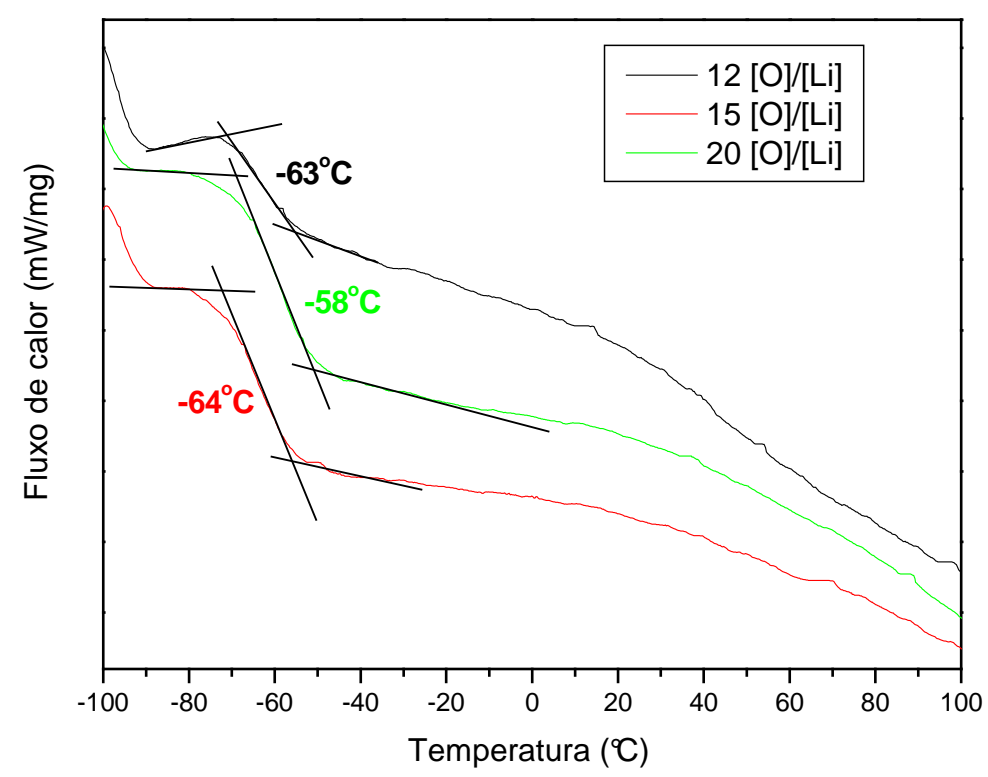

Figura 4.23 - Curvas de DSC para filmes de amido nativo plastificado com 30\% de sorbitol e contendo diferentes razões de $[\mathrm{O}] /[\mathrm{Li}]$.

Em relação à estrutura das amostras foi observado que a quantidade de perclorato de lítio adicionada aos ESPs preparados com amido de mandioca nativo e modificados não alterou a cristalinidade do mesmos. A Figura 4.24 apresenta o difratograma de raios-X para amostras de amido de mandioca nativo e acetilado com diferentes quantidades de sal de lítio, onde nota-se que as amostras apresentam comportamento predominantemente amorfo. 


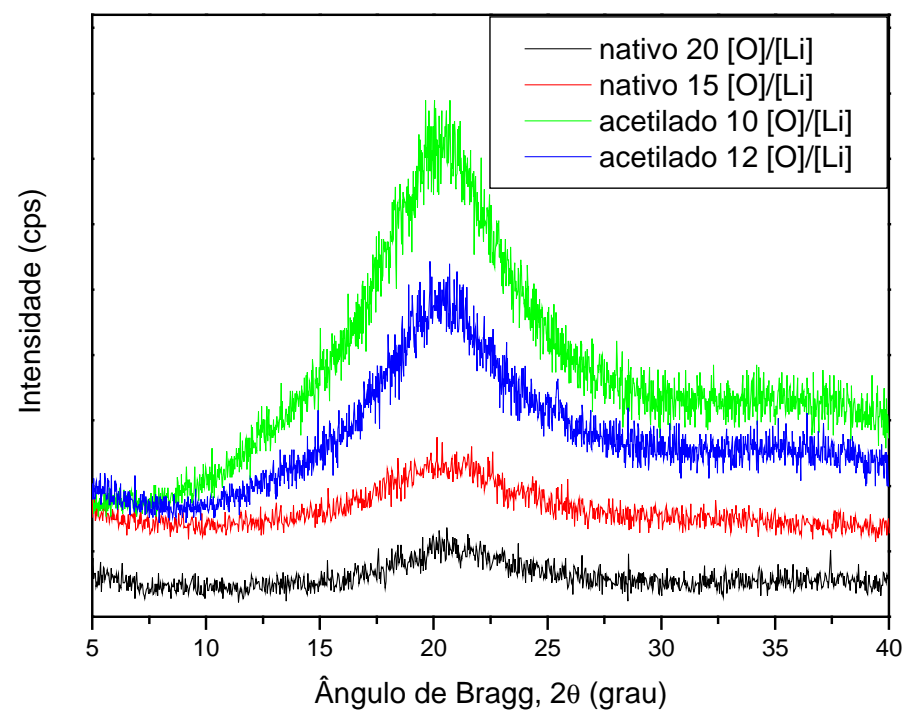

Figura 4.24 Difração de raios-X dos amidos: nativo, plastificados com 30\% de sorbitol, contendo 15 e 20 [O]/[Li] e acetilado, plastificados com 30\% de glicerol, contendo 10 e 12 $[\mathrm{O}] /[\mathrm{Li}]$.

As propriedades higroscópicas das amostras podem ser verificadas através de termogravimetria (TGA). Nota-se nas Figuras 4.25 e 4.26, que as amostras de amido possuem uma quantidade de água retida em seus grânulos de aproximadamente $11 \%$, que é eliminada devido ao aquecimento entre $25^{\circ} \mathrm{C}$ até $120^{\circ} \mathrm{C}$ e visualizado através da perda de massa neste intervalo de temperatura.. Após a preparação dos filmes esta quantidade de água diminui, devido a secagem dos mesmos em estufa a $40^{\circ} \mathrm{C}$ e armazenamento em dessecadores. No entanto, quando para grandes quantidades de lítio no filme $(8[\mathrm{O}] /[\mathrm{Li}])$, a perda de massa é maior do que quando as quantidades de lítio são menores $(30[\mathrm{O}] /[\mathrm{Li}])$, isto ocorre devido a uma maior absorção de água do ar dos filmes com maiores quantidades de lítio. A saída desta água pode ocorrer até aproximadamente $200^{\circ} \mathrm{C}$. A partir de 264 a $334^{\circ} \mathrm{C}$ há uma brusca perda de massa, em torno de 
$70 \%$ cuja causa é a degradação das amostras. Esta mudança é citada na literatura como reação endotérmica, com possíveis reações de hidrolise e de oxidação, seguida por reações exotérmicas de 340 a $520^{\circ} \mathrm{C}$, que corresponde ao estágio final da pirólise ${ }^{17}$. Acima de $360^{\circ} \mathrm{C}$ a perda de $\pm 24 \%$ de massa é referente provavelmente a pirólise do amido. Os teores de cinzas para estas amostras foram de $\pm 6 \%$, devido aos produtos formados pela oxidação de lítio.

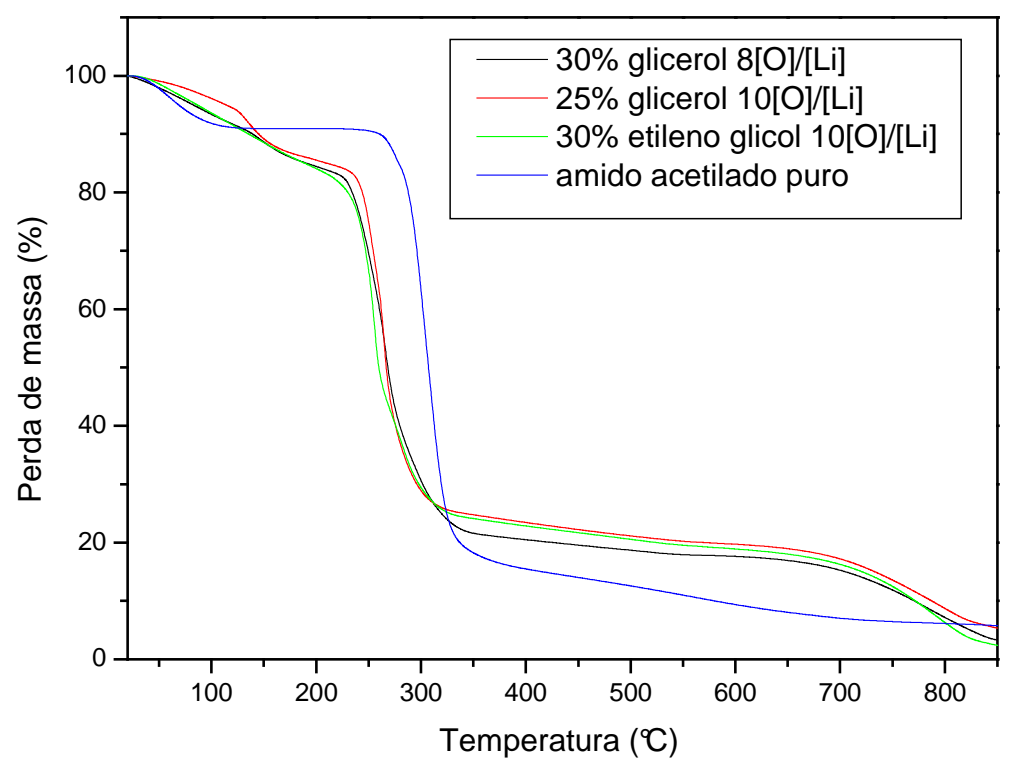

Figura 4.25 - Curvas de análise térmica (TGA) para as amostras de amido acetilado puro e plastificado com glicerol e com etileno glicol. 


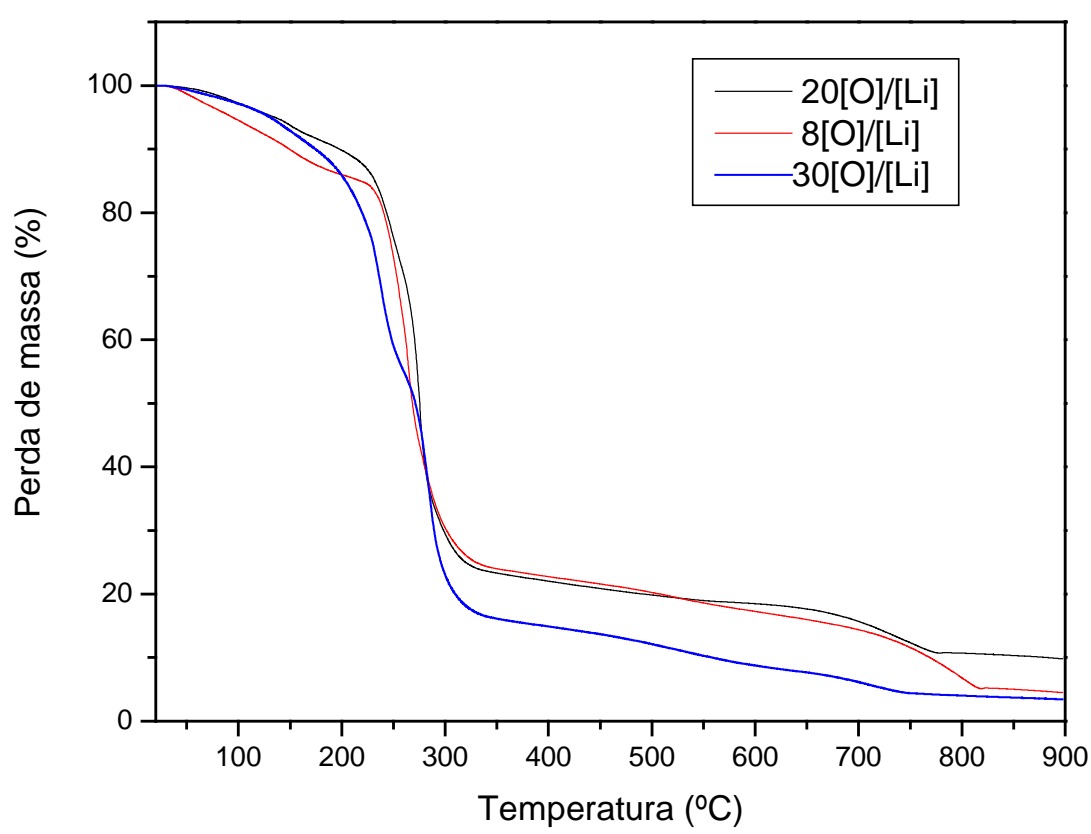

Figura 4.26 - Curvas de análise térmica (TGA) para a amostra de amido oxidado-acetilado com $30 \%$ de glicerol e contendo diferentes quantidades de sal.

A análise destes gráficos revela que a presença do plastificante e do sal de lítio no filme promove uma diminuição da temperatura de degradação das amostras estudadas. Enquanto o amido nativo puro se degrada à $307^{\circ} \mathrm{C}$, o amido acetilado puro a $305^{\circ} \mathrm{C}$ e o amido oxidadoacetilado a $294^{\circ} \mathrm{C}$. Como pode ser visto pelas primeiras derivadas das curvas de TGA na Figura 4.27, as amostras plastificadas (com glicerol e com perclorato de lítio) e contendo sal (de 30 a $8[\mathrm{O}] /[\mathrm{Li}])$, se degradam de $260-285^{\circ} \mathrm{C}$, como pode ser observado nas Figuras 4.28 e 4.29. Esta última apresenta as temperaturas de degradação das amostras obtidas pela primeira derivada. Isto sugere a influência de alguns fatores, como por exemplo, a presença de água e de glicerol no sistema, que favorecem os rearranjos intermoleculares e facilitam a degradação do amido. 
Entretanto, o fator principal pode ser a presença de um íon mineral $\left(\mathrm{Li}^{+}\right)$que pode agir como um catalisador nas reações de decomposição. Porém apesar de ocorrer esta diminuição da temperatura de degradação ainda se pode afirmar que os filmes obtidos são bastante estáveis.

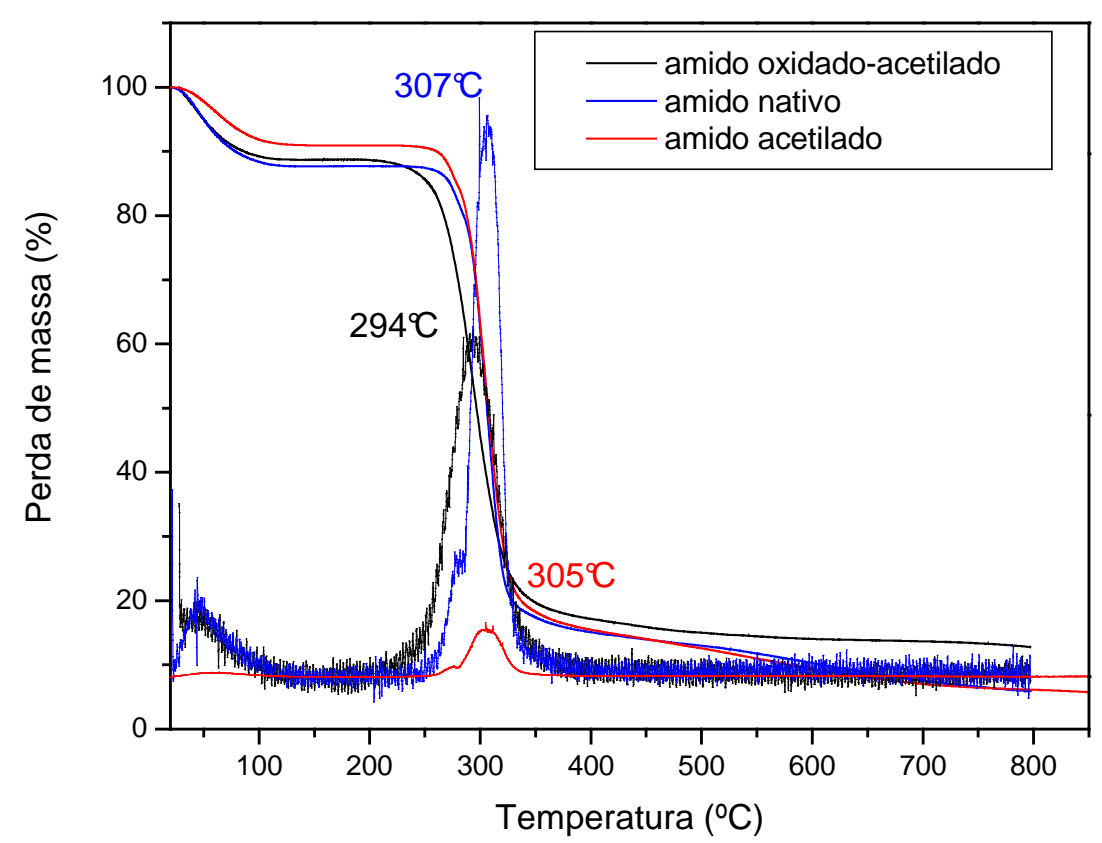

Figura 4.27 - Curvas de TGA e as primeiras derivadas para as amostras de amido puro: nativo, acetilado e oxidado-acetilado. 

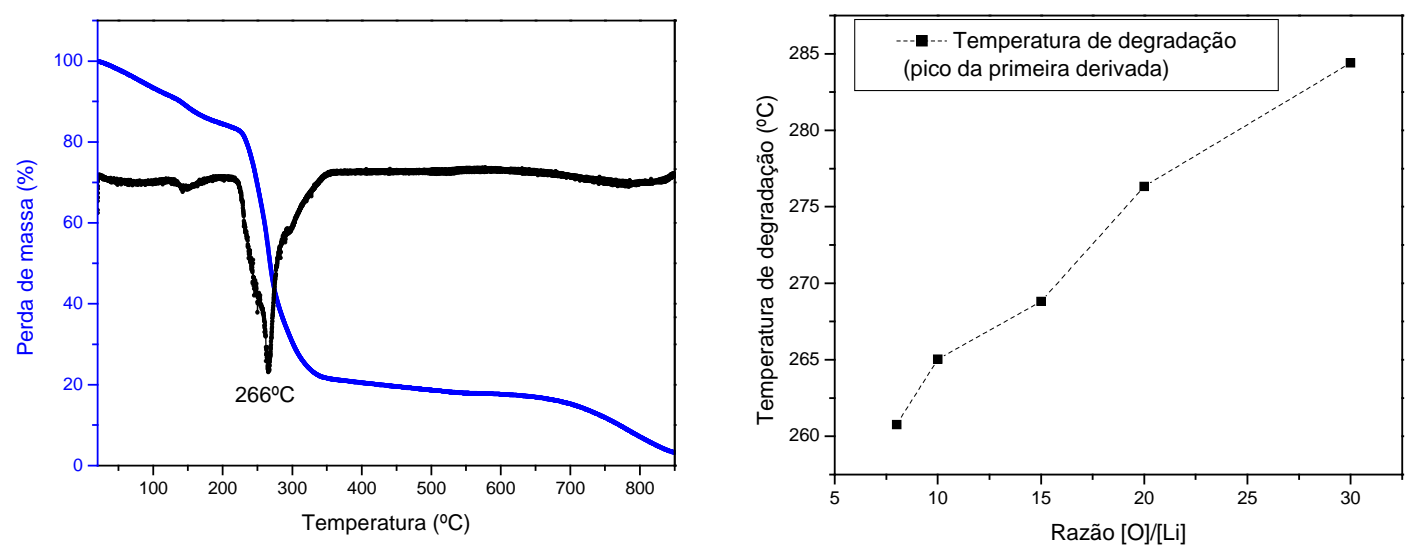

Figura 4.28 - Curva de TGA e a Figura 4.29 - Temperatura de degradação primeira derivada para amostra de dos filmes de amido acetilado com $30 \%$ amido acetilado com 30\% de glicerol e glicerol em função da razão [O]/[Li], obtidas $10[\mathrm{O}] /[\mathrm{Li}]$. pelo pico da primeira derivada.

A superfície das amostras de amido plastificado com glicerol e contendo $\mathrm{LiClO}_{4}$, foi visualizada através de análises por microscopia eletrônica de varredura (Figura 4.30). Como já foi comentado, as amostras de amido são constituídas de grânulos que após o processo de plastificação são rompidos, resultando em filmes predominantemente amorfos. Os filmes contendo o sal de lítio também apresentaram uma boa uniformidade, sem a presença de grânulos ou cristais. 


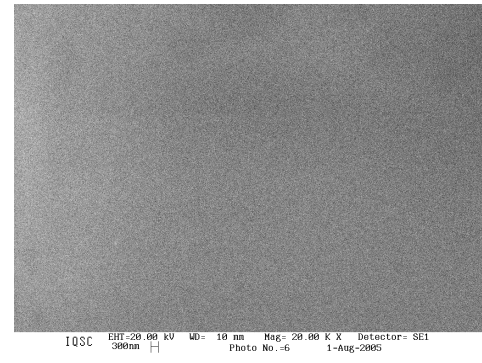

amido acetilado $10[\mathrm{O}] /[\mathrm{Li}]$

amido nativo $10[\mathrm{O}] /[\mathrm{Li}]$
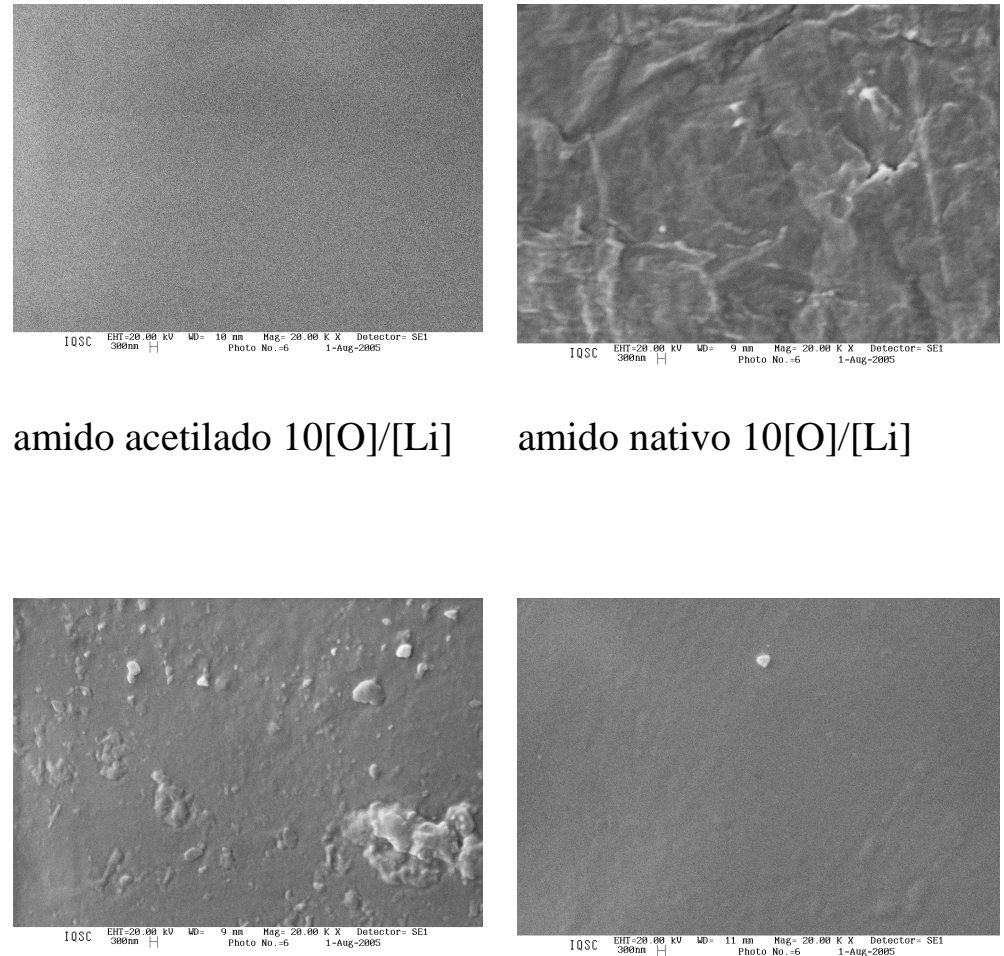

amido acetilado 30[O]/[Li]

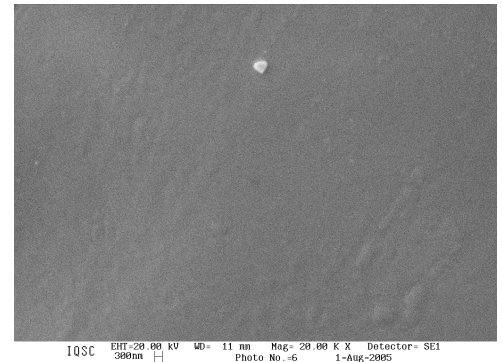

amido nativo $30[\mathrm{O}] /[\mathrm{Li}]$ amido oxidado-acetilado

amido oxidado-acetilado

$10[\mathrm{O}] /[\mathrm{Li}]$
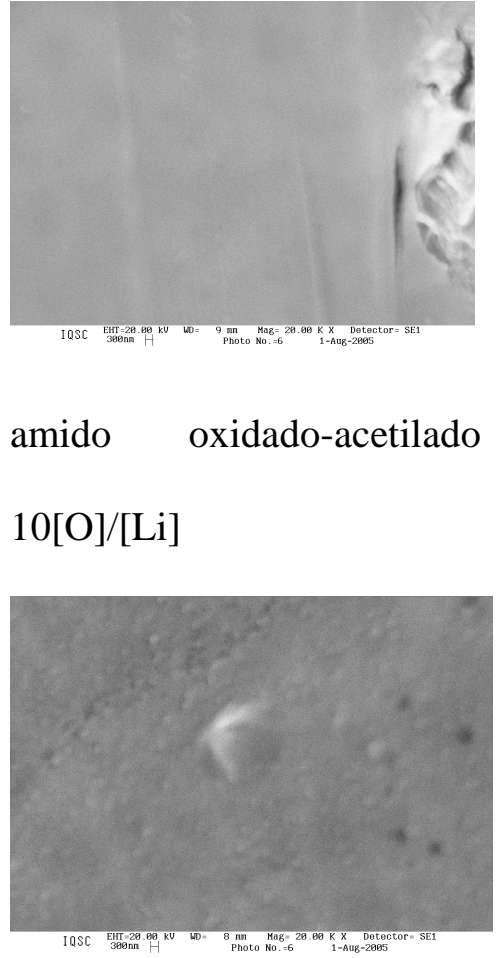

amido oxidado-acetilado $30[\mathrm{O}] /[\mathrm{Li}]$

Figura 4.30 - Micrografias dos filmes de amido nativo, amido acetilado e amido oxidadoacetilado com $30 \%$ de glicerol e nas concentrações de 10 e $30[\mathrm{O}] /[\mathrm{Li}]$ com aumento de 20000x.

Entretanto, pode ser notado que as amostras com elevadas quantidades de sal são mais rugosas, principalmente a amostra de amido nativo. Isso pode ser devido exatamente à elevada concentração do sal. As amostras com menores concentrações de sal parecem ser mais flexíveis o que é evidenciado através de ondulações nos filmes. Isso também é uma evidência de uma boa aderência dos filmes ao substrato, já que foi difícil coloca-los sobre o porta-amostras, pois os mesmos aderiam as espátulas. 


\subsection{4 - Transparência dos ESPs a base de amido de mandioca modificado.}

Neste projeto foram preparados e caracterizados amostras de ESPs a base de blendas de amidos de mandioca puro e modificados. O objetivo deste trabalho foi conseguir uma melhor condutividade iônica, comparado aos trabalhos previamente desenvolvidos com o amido de milho rico em amilopectina ${ }^{7}$. Ao utilizar um polímero para a obtenção de um eletrólito sólido, é necessário que o mesmo tenha a capacidade de solvatar o íon, ou seja, possua em sua estrutura heteroátomos, como por exemplo, o oxigênio, os quais contam com pares de elétrons livres que promovem a dissociação do sal. Através das reações de oxidação e acetilação do amido foi possível a obtenção de maior quantidade de átomos oxigênio em sua estrutura, o que contribuiu para uma melhora nos valores da condutividade iônica.

Por outro lado para que um eletrólito sólido polimérico seja aplicado em janelas eletrocrômicas, é necessário além de uma boa condutividade iônica, que também seja transparente na região do visível do espectro eletromagnético. Assim na Figura 4.31, estão apresentados os espectros de UV-VIS para as amostras de amido nativo, amido acetilado e amido oxidado-acetilado, com 30\% de glicerol e com [O]/[Li] $=10$ e 30 . 


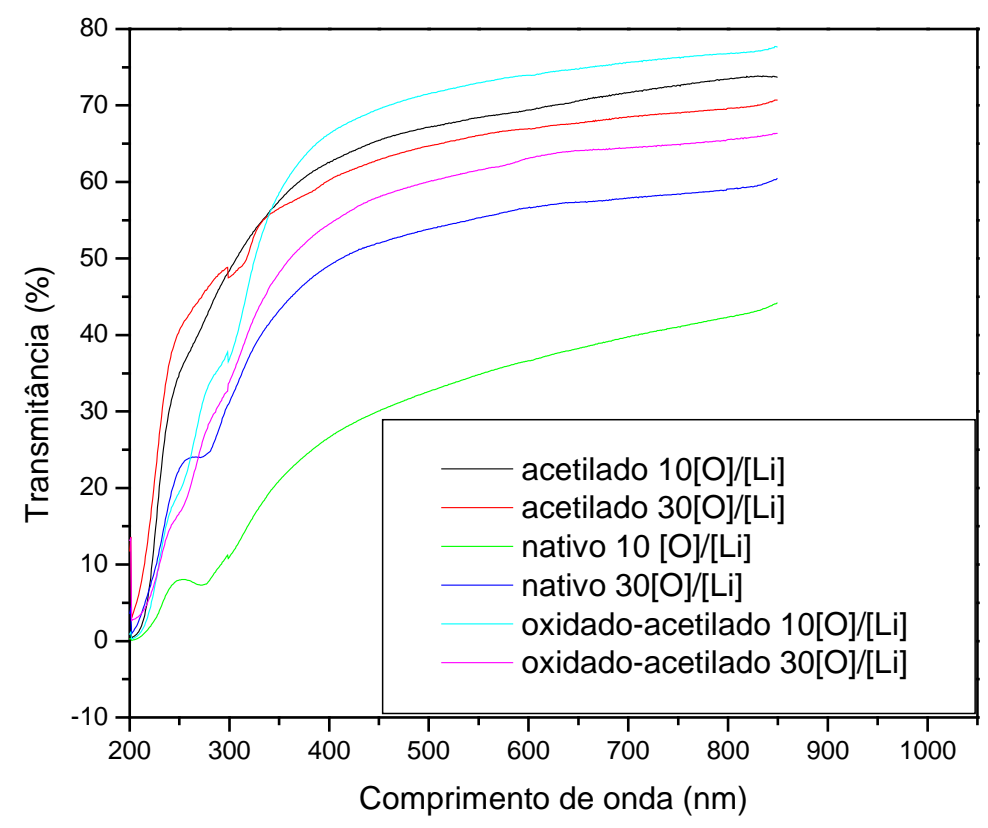

Figura 4.31 - Espectros de UV-VIS para os filmes de amido nativo, acetilado e oxidado-acetilado com 30\% de glicerol e contendo $[\mathrm{O}] /[\mathrm{Li}]=10$ e 30 .

Como pode ser observado nesta figura, os filmes apresentam elevados valores de transmitância, sendo próxima de $80 \%$ para o amido oxidado-acetilado e contendo 10 [O]/[Li]. Os valores de transmitância de 60 a $70 \%$ foram encontrados para o para o amido oxidado-acetilado e acetilado contendo $30[\mathrm{O}] /[\mathrm{Li}]$. Os filmes de amido nativo apresentaram menor transparência, de aproximadamente $40 \%$ quando comparados com amostras a base dos amidos modificados, principalmente para o amido nativo contendo $10[\mathrm{O}] /[\mathrm{Li}]$.

Como a transmitância depende também da espessura das amostras, a tabela 4.8 apresenta as espessuras obtidas para os filmes analisados. 
Tabela 4.8- Espessuras dos filmes a base de amido nativo, acetilado e oxidado-acetilado com $30 \%$ de glicerol e contendo $[\mathrm{O}] /[\mathrm{Li}]=10$ e 30

\begin{tabular}{|l|c|c|c|c|c|c|}
\hline Tipo de amido & \multicolumn{2}{l|}{ Nativo } & \multicolumn{2}{l|}{ Acetilado } & \multicolumn{2}{l|}{ Oxidado e acetilado } \\
\hline Razão [O]/[Li] & 10 & 30 & 10 & 30 & 10 & 30 \\
\hline Espessura medida (cm) & 0,032 & 0,022 & 0,028 & 0,022 & 0,022 & 0,017 \\
\hline
\end{tabular}

Contudo, estes filmes podem ser considerados transparentes na região visível, o que é de grande importância para a possível utilização destes eletrólitos em dispositivos eletrocrômicos, como janelas eletrocrômicas. Na região do ultravioleta (200 a $400 \mathrm{~nm}$ ), os valores de transmitância dos filmes aumentam de próximo de zero em 200 nm, para respectivos valores na região visível.

Portanto o amido acetilado com uma concentração de sal de lítio de 10[O]/[Li], devido a seu baixo valor de $\mathrm{T}_{\mathrm{g}}$, ser predominantemente amorfo, possuir uma ótima transparência e uma boa condutividade, apresentou-se como o melhor material para ser utilizado como eletrólito sólido polimérico, para o uso em dispositivos eletrocrômicos.

Comparando os trabalhos previamente desenvolvidos com o amido de milho rico em amilopectina $^{7}$, o amido acetilado e plastificado com glicerol, com uma razão de $[\mathrm{O}] /[\mathrm{Li}]=10$ apresentou condutividade iônica de $4,61 \cdot 10^{-4} \mathrm{~S} / \mathrm{cm}$, enquanto que o amido de milho rico em amilopectina apresentou condutividade iônica de $3,27 \cdot 10^{-5} \mathrm{~S} / \mathrm{cm}$ nas mesmas condições empregadas. Também a transparência obtida para o filme de amido acetilado (70\%) foi bem maior quando comparada às amostras a base de amido de milho rico em amilopectina (40\%). 
Referências Bibliográficas

1 CEREDA, M. Pascoli (Coord.). Culturas de tuberosas amiláceas latino-americanas.

Propriedades gerais do amido. São Paulo: Fundação Cargill, 2002. v. 1

2 WURZBURG, O. B. Starch derivates and modification. In: WHISLER, L. (Ed.). Methods in Carbohydrate Chemistry IV. New York : Acad. Press, 1964. p. 286-288.

3 NICOTERA, I.; RANIERI, G.A.; TERENZI, M.; CHADWICK, A.V.; WEBSTER, M. I. A study of stability of plasticized PEO electrolytes. Solid State Ionics, v. 146, n. 1-2, p. 143-150, 2002.

4 MORITA, M.; ARAKI, F.; KASHIWAMURA, K.; YOSHIMOTO, N.; ISHIKAWA, M. Ionic structure and conductance behavior of plasticized polymeric electrolytes containing multivalent cations. Electrochimica Acta, v. 45, n. 8-9, p. 1335-1340, 2000.

5 STEPHAN, A.M.; KUMAR, T.P.; RENGANATHAN, N.G.; PITCHUMANI, S.;

THIRUNAKARAN, R.; MUNIYANDI N. Ionic conductivity and FT-IR studies on plasticized PVC/PMMA blend polymer electrolytes. Journal of Power Sources, v. 89, n. 1, p. 80-87, 2000.

6 LIDE, D.R.( Ed.). Handbook of Chemistry and Physics. 81. Boca Raton: CRC Press, 2000. Cap.6, p.149-171.

7 DRAGUNSKI, D. C. Preparação de eletrólitos sólidos poliméricos a partir do amido. 2003. Tese (Doutorado) - Instituto de Química de São Carlos, Universidade de São Paulo, São Carlos, 2003.

8 GUimarães, K. V. Eletrólitos Sólidos Poliméricos a base de Amido plastificado com Etileno Glicol, Carbonato de Propileno e mistura de Etileno Glicol com Poli(etileno glycol). 2003. Dissertação (Mestrado) - Instituto de Química de São Carlos, Universidade de São Paulo, São Carlos, 2003. 
9 LOURDIN, D.; BIZOT, H.; COLONNA, P. "Antiplasticization" in starch-glycerol films Journal Applied Polymer Science, v. 63, n. 8, p. 1047-1053, 1997.

10 LORCKS J. Properties and application of compostable starch-based plastic material. Polymer Degradation and Stabability, v. 59, p. 245-249, 1998.

11 CHEN, H.W.; LIN, T.P.; CHANG, F.C. Ionic conductivity enhancement of the plasticized PMMA/LiClO 4 polymer nanocomposite electrolyte containing clay. Polymer, v. 43, p. 5281$5288,2002$.

12 KIM, Y.T.; SMOTKIN, E.S. The effect of plasticizers on transport and electrochemical properties of PEO-based electrolytes for lithium rechargeable batteries. Solid State Ionics, v. 149, p. $29-37,2002$.

13 NEYERTZ, S.; BROWN, D. Local structure and mobility of ions in polymer electrolytes: A molecular dynamics simulation study of the amorphous PEO(x)NaI system. Journal of Chemical Physics, v. 104, n. 10, p. 3797-3809, 1996.

14 WARD, I.M.; BODEN, N.; CRUICKSHANK, J.; LENG, S.A. NMR-studies of tonic mobility and molecular mobility in polymer electrolytes. Electrochimica Acta, v. 40, n. 13-14, p. 2071-2076, 1995.

15 CARVALHO, L. M.; GUEGAN, P.; CHERADAME, H.; GOMES, A.S. Variation of the mesh size of PEO-based networks filled with TFSILi: from an Arrhenius to WLF type conductivity behavior. European Polymer Journal, v.36, n.2, p.401-409, 2000.

16 VAN SOEST, J.J.G.; VLIEGENTHART, F.G.J. Crystallinity in starch plastics: consequences for material properties. Trends in Biotechnology, v. 15, p. 208-213, 1997.

17 COLONNA, P.; BULEON, A.; MERCIER, C. Physically modified starches. In: STARCH: Properties and Potencial. Great Brintain: Society of Chemical Industry. 1987. 79p. 


\section{Capítulo 5 - Conclusões}

Os eletrólitos poliméricos foram obtidos utilizando-se amido de mandioca nativo e modificados (acetilado e oxidado-acetilado).

A análise da matéria-prima utilizada para este estudo revelou, que o amido nativo realmente sofreu modificações com as reações de acetilação e de oxidação, as quais foram confirmadas, principalmente, pelas técnicas de FT-IR e RMN. Pelo FT-IR, observou-se o aparecimento da banda de absorção relativa ao $\mathrm{C}=\mathrm{O}\left(1747 \mathrm{~cm}^{-1}\right)$. Utilizando $\mathrm{RMN}$ de ${ }^{1} \mathrm{H}$, constatou-se o surgimento dos picos em 2,05 ppm para o amido acetilado e 2,03 e 1,85 ppm para o amido oxidado-acetilado.

Verificou-se também a distribuição de massa molecular para as amostras onde foi possível observar alterações para as amostras de amido modificados e confirmar que a modificação do amido por reação de oxidação ocasionou quebra de ligações aumentando a polidispersividade da amostra de amido oxidado-acetilado em relação à amostra de amido de mandioca nativo. Calculou-se o grau de substituição para os amidos de mandioca modificados e determinou-se a composição percentual de carbono, hidrogênio e oxigênio para as diferentes amostras de amido utilizadas neste projeto.

Utilizando o MEV, constatou-se que todos os filmes preparados apresentaram-se homogêneos e uniformes. 
Observou-se, que o melhor plastificante empregado é o glicerol e que aumentando a quantidade de glicerol houve um aumento da condutividade, ou seja, o glicerol está ajudando na solvatação dos íons, entretanto acima de $30 \%$ de glicerol, as amostras perderam seu caráter filmógeno, tornando-se gel, por isso decidiu-se trabalhar com um concentração de glicerol de $30 \%$ em massa de amido. O melhor valor de condutividade a $30^{\circ} \mathrm{C}$ para o amido acetilado foi para a razão de $8[\mathrm{O}] /[\mathrm{Li}]\left(1,23 \times 10^{-4} \mathrm{~S} / \mathrm{cm}\right)$, para o amido oxidado-acetilado foi para a razão de $10[\mathrm{O}] /[\mathrm{Li}]\left(7,38 \times 10^{-5} \mathrm{~S} / \mathrm{cm}\right)$, para o amido nativo foi para a razão de $12[\mathrm{O}] /[\mathrm{Li}]\left(8,367 \times 10^{-5}\right.$ S/cm). Notou-se que a região onde estão os melhores valores de condutividade, entre 12 $8[\mathrm{O}] /[\mathrm{Li}]$, possui a menor energia de ativação e $\mathrm{T}_{\mathrm{g}}$.

Também foi observado que os filmes obtidos mostraram-se transparentes na região do visível, o que é de grande importância para a utilização destes eletrólitos em janelas eletrocrômicas.

Notou-se que o filme com maior quantidade de plastificante possui maior valor de condutividade, comprovando o auxílio do plastificante na dissociação do sal.

Portanto, pode-se constatar que os amidos de mandioca nativo e/ou modificados, plastificados possuem todas as qualidades de um bom eletrólito sólido polimérico e que possivelmente são excelentes candidatos a equipar futuros dispositivos eletrocrômicos. 